\title{
Seagrass: A Dynamic System
}

\section{Alison Duncan}

A Thesis submitted to Victoria University of Wellington in partial fulfilment of the requirements of the degree of Master of Science in Marine Biology.

Victoria University of Wellington

February 2017 



\section{Acknowledgments}

This thesis could not have been achieved without the help and support of friends, colleagues and family. I should especially like to thank Nicole Phillips for all the support, advice and being so easy to talk with. I also thank Megan Oliver (Greater Wellington Regional Council), Fleur Matheson (NIWA), and Leigh Stevens and Barry Robertson (Wriggle Coastal Management) for their advice and guidance over the last two years.

To Mel Dohner and Jana Wold, thank you for your part in maintaining my sanity throughout this process, and for all your help with field work, the experiments and proof reading. Also for reminding me to have fun!

Thanks also to all my field volunteers, and a particular thankyou to Conor Neilson for both the field work and the statistics advice. Also the VUCEL technicians and Jen Howes for their advice and assistance over the last two years.

To my parents, thank you for supporting me throughout my education, and for sparking my love of science. To Sophie, Dion, Laura and Fin, thank you for all your support and laughter which has kept me sane and smiling, even during the tough times. Also for enduring the stench of mud that pervaded many layers of skin and clothing.

This work was carried out under the tenure of the Masters by Thesis Scholarship by the VUW Scholarships Committee. 


\section{Abstract}

Seagrass meadows stabilise sediment, reduce coastal erosion, provide habitat for many species, and boost productivity in nearby systems through detritus. Changes in seagrass characteristics, such as biomass, cover or blade area, and algal epiphyte loading can therefore alter the wider system. However, these have been less well studied in New Zealand than other systems around the world. Small herbivorous invertebrates consume algal epiphytes, increasing light availability to seagrass blades, as well as providing an important trophic link between primary producers and larger consumers. Of the invertebrate grazers associated with seagrass, much research to date has focused on crustaceans, and comparatively little on gastropods, even though they can be abundant. The aim of this research was to 1) examine seasonal and spatial variation in seagrass and associated gastropods in a large estuarine system in the lower North Island of New Zealand (Porirua Harbour) and 2) examine the response of seagrass and epiphytic algae to nutrient enrichment and grazing pressure in a laboratory experiment.

To assess the seasonal fluctuations in the associated gastropods and relationships with seagrass and epiphyte biomass within the Porirua Harbour, surveys were conducted in summer and winter of 2016 across three sites. Overall, seagrass above-ground biomass decreased between summer and winter, while blade area increased. Gastropod grazer densities were greatest in summer, and epiphytic algae showed seasonal trends, with evidence of a loss of grazer control on epiphytes during winter. Potamopyrgus estuarinus, Notoacmea scapha, Diloma spp. and Micrelenchus spp. were the dominant gastropod grazers in the system in both seasons. The gastropod assemblage and seagrass characteristics also differed between sites separated by up to $4 \mathrm{~km}$ within the harbour, likely in response to small scale differences in abiotic factors (e.g. turbidity, fresh water or nutrient inputs, etc.).

To investigate the effect of three of the dominant grazers (Diloma spp., N. scapha, and P. estuarinus) and nutrient enrichment on epiphyte and seagrass growth, experiments were run in outdoor tanks at Victoria University's Coastal Ecology Lab (VUCEL) using seagrass from two different sites: Elsdon (a site with elevated nutrient levels) and 
Browns Bay (a relatively pristine site). Three nutrient treatments included a High level that used nitrate and phosphate levels similar to those found at Elsdon (143 $\mathrm{mg} \mathrm{m}^{-3}$ $\mathrm{NO}_{3}-\mathrm{N}$ and $9 \mathrm{mg} \mathrm{m}^{-3}$ dissolved reactive phosphate), High + which was a $20 \%$ increase of the High level, and a Control with no added nutrients. Little evidence was found for epiphyte regulation by gastropods, nor did epiphyte loads increase with nutrient addition. The response of seagrass to nutrient addition depended on the site where it was obtained, with seagrass from Browns Bay growing slower in High+ than Control or High treatments. Overall, Elsdon seagrass grew faster, despite higher epiphyte biomass, and irrespective of nutrient treatment. The results of the experiments suggest that seagrass from Elsdon is adapted to the site's high nutrient loads, where seagrass from Browns Bay is not. These differences in adaptations demonstrate the need to manage seagrass on a site, rather than harbour, scale. This will aid the ongoing management and monitoring of the Porirua Harbour by Porirua City Council and Wellington Regional Council. Finally, the results of this thesis support prior research findings of high variation in seagrass over a small scale, and adds to the currently lacking information on the role of micro-grazers in New Zealand's seagrass meadows. 


\section{Table of Contents}

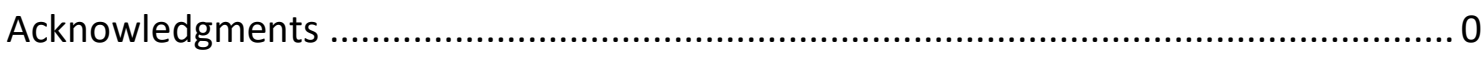

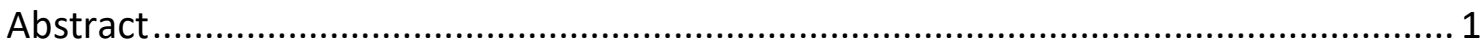

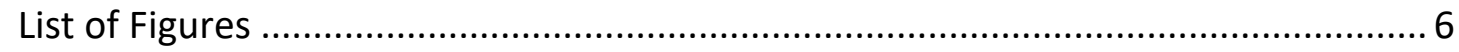

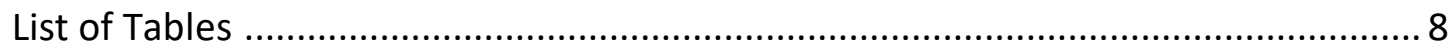

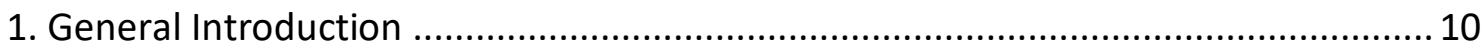

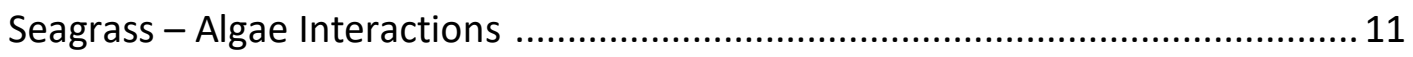

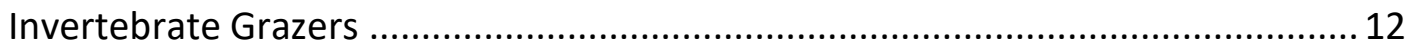

The Complications of Eutrophication ........................................................... 15

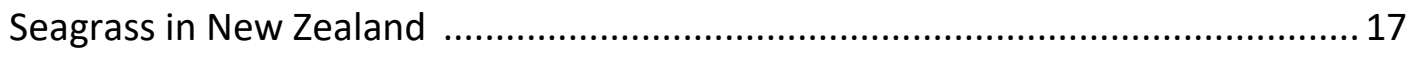

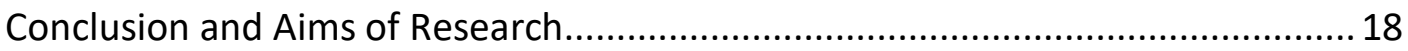

2. Temporal and Spatial Variation in Seagrass Associated Gastropod Communities of

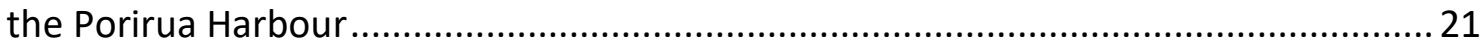

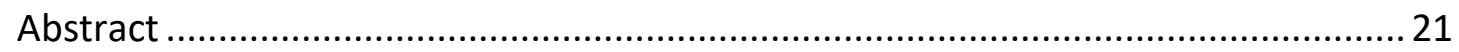

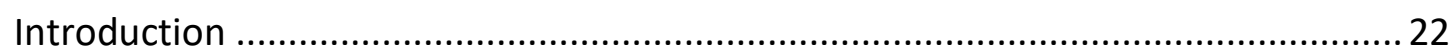

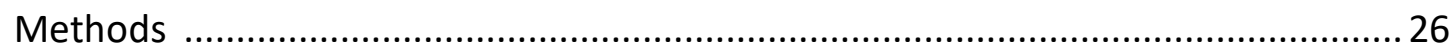

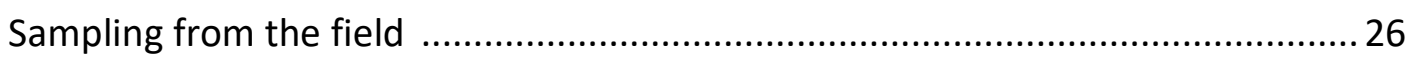

Assessment of seagrass blade traits and epiphytes ......................................... 26

Assessment of seagrass biomass and invertebrates …...................................... 27

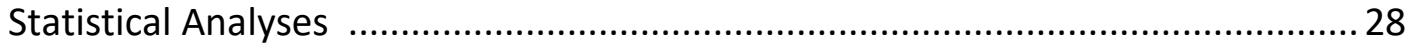

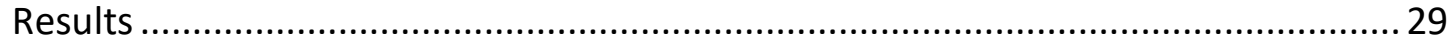

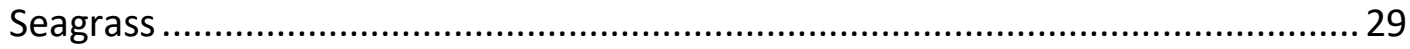

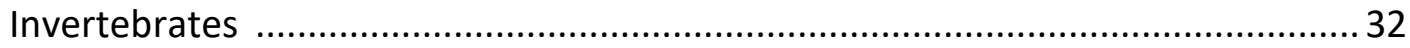

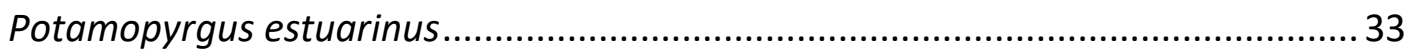

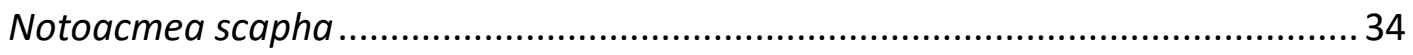

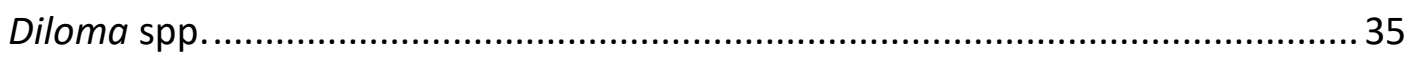




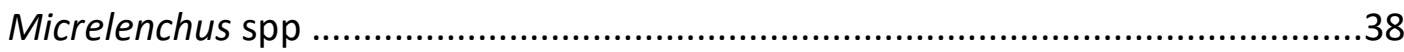

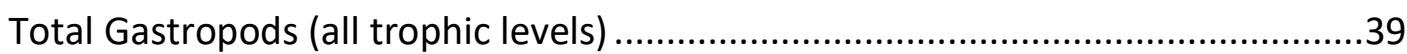

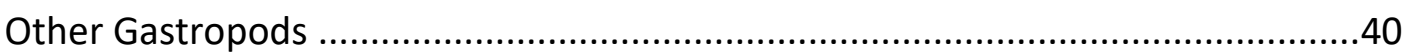

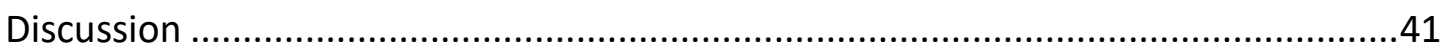

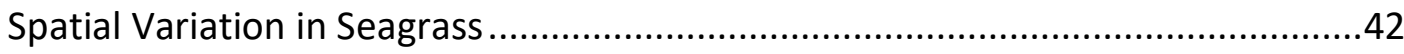

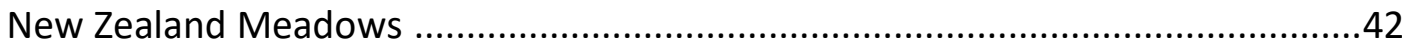

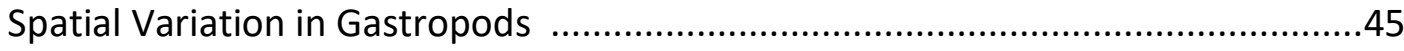

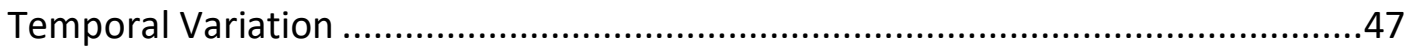

3. Effects of Nutrient Addition and Gastropod Grazers on Seagrass from Different Sites

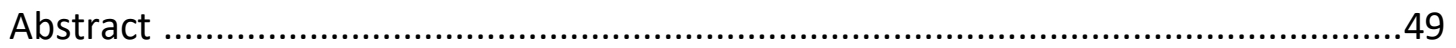

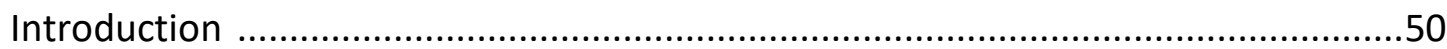

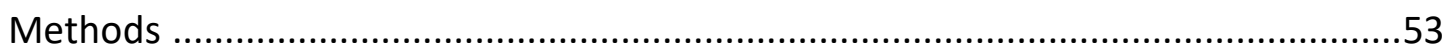

Collection and Acclimation of Seagrass from Low Nutrient Input Site (Browns Bay)

Collection and Acclimation of Seagrass from High Nutrient Input Site (Elsdon) ....56

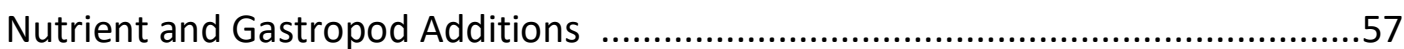

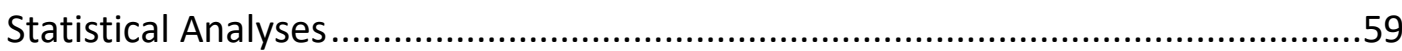

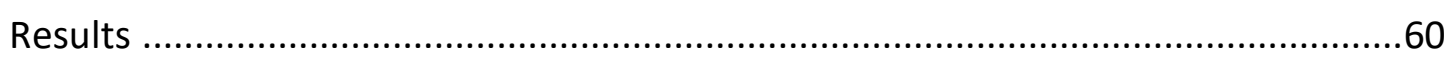

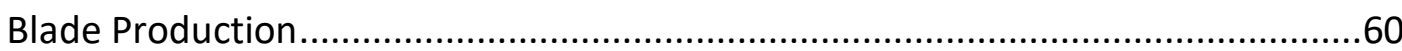

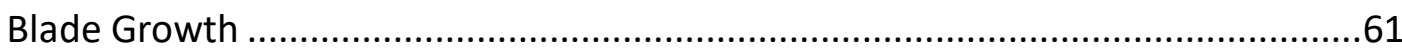

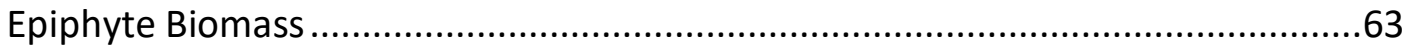

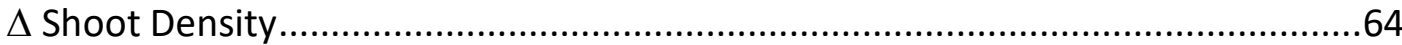

Relationship Between Seagrass Attributes ......................................................66

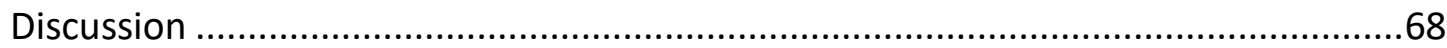

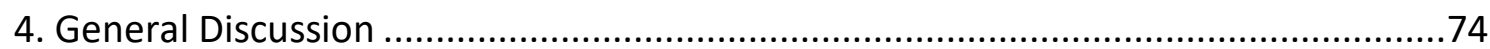




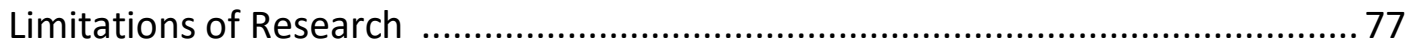

Conclusions and Suggestions for Further Research ......................................... 78

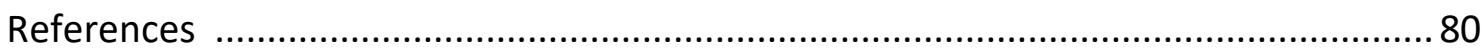

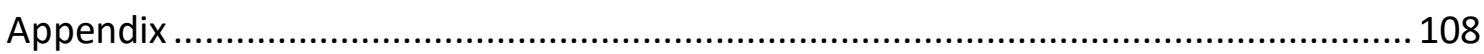

109 


\section{List of Figures}

Figure 1.1: Location of the Porirua Harbour. (a) The map of the world shows the location of (b) New Zealand, with (c) arrow indicating the Porirua Harbour .................18

Figure 2.1: Map of sites sampled within the Porirua Harbour.....................................25

Figure 2.2: Average above-ground biomass of seagrass from sites in Porirua Harbour in (a) summer and (b) winter. .29

Figure 2.3: Average blade area of seagrass from sites in Porirua Harbour in (a) summer and (b) winter. .30

Figure 2.4: Proportion of mostly ( $>50 \%$ ) green blades in summer and winter .31

Figure 2.5: Representatives of the four main gastropod genera .32

Figure 2.6: Average density of Potamopyrgus estuarinus on seagrass from sites in Porirua Harbour in (a) summer and (b) winter .33

Figure 2.7: Average density of Notoacmea scapha on seagrass from sites in Porirua Harbour in (a) summer and (b) winter .34

Figure 2.8: Average density of Diloma spp. on seagrass from sites in Porirua Harbour in (a) summer and (b) winter . .36

Figure 2.9: Average density of Diloma sp. associated with seagrass in Porirua Harbour in (a) summer and (b) winter . .37

Figure 2.10: Average total density of Micrelenchus spp. associated with seagrass from sites in Porirua Harbour in (a) summer and (b) winter .38

Figure 2.11: Average total density of all gastropods associated with seagrass from sites in Porirua Harbour in (a) summer and (b) winter .39

Figure 3.1: Examples of tanks of Browns Bay seagrass .54

Figure 3.2: Outdoor seatable with the nine Browns Bay tanks wrapped in black plastic .55

Figure 3.3: Browns Bay seagrass submerged in indoor seatable .56

Figure 3.4: Average number of 'new' blades in (a) Browns Bay and (b)Elsdon trials .....61

Figure 3.5: Average blade growth over a 3- week period in (a) Browns Bay and (b)

Elsdon trials .62

Figure 3.6: Average epiphyte biomass in (a) Browns Bay and (b) Elsdon trials .64 
Figure 3.7: Average change in shoot density between the beginning and end of (a)

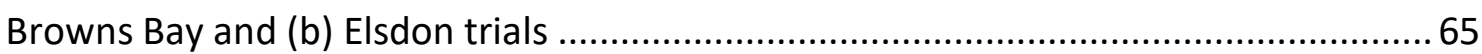

Figure 3.8: Relationship between number of blades per container and average seagrass blade growth in the Browns Bay trial .66

Figure 3.9: Relationship between number of blades per container and average new blade production per container in the Browns Bay trial 67

Figure 3 10: Relationship between number of blades per container and epiphyte biomass in the Elsdon trial. 67

Figure A3.1: Tank positioning for the Browns Bay trial 110

Figure A3.2: Tank positioning in the Elsdon trial 110 


\section{List of Tables}

Table 2.1: Results of PERMANOVA examining effects of season, site and tidal height on seagrass above-ground biomass $\left(\mathrm{g} \mathrm{DW}^{-1} \mathrm{~m}^{-2}\right)$ in the Porirua Harbour .29

Table 2.2: Results of PERMANOVA examining effects of season, site and tidal height on blade area in the Porirua Harbour . .30

Table 2.3: Results of PERMANOVA examining effects of season, site and tidal height on density of Potamopyrgus estuarinus in the Porirua Harbour

Table 2.4: Results of PERMANOVA examining effects of season, site and tidal height on density of Notoacmea scapha in the Porirua Harbour .34

Table 2.5: Results of PERMANOVA examining effects of season, site and tidal height on density of Diloma spp. in the Porirua Harbour .35

Table 2.6: Results of PERMANOVA examining effects of season and site on Diloma subrostrata densities in the Porirua Harbour

Table 2.7: Results of PERMANOVA examining effects of season and site on Diloma arida densities in the Porirua Harbour

Table 2.8: Results of PERMANOVA examining effects of season and site on Diloma zelandica densities in the Porirua Harbour

Table 2.9: Results of PERMANOVA examining effects of season, site and tidal height on density of Micrelenchus spp. in the Porirua Harbour

Table 2.10: Results of PERMANOVA examining effects of season, site and tidal height on density of all gastropods in the Porirua Harbour

Table 2.11: Summary of selected previous studies on seagrass above-ground biomass blade width and blade length around New Zealand

Table 3.1: The full factorial design to test the effects of nutrient addition and gastropod presence on seagrass growth and epiphyte biomass

Table 3.2: Results of two-way PERMANOVA examining the effects of nutrient addition and gastropods on new blade production in the Browns Bay trial .60 Table 3.3: Results of two-way PERMANOVA examining the effects of nutrient addition and gastropods on new blade production in the Elsdon trial 60

Table 3.4: Results of two-way PERMANOVA examining the effects of nutrient addition and gastropods on blade growth in the Browns Bay trial 
Table 3.5: Results of two-way PERMANOVA examining the effects of nutrient addition and gastropods on blade growth in the Elsdon trial

Table 3.6: Results of two-way PERMANOVA examining the effects of nutrient addition and gastropods on epiphyte biomass in the Browns Bay trial

Table 3.7: Results of two-way PERMANOVA examining the effects of nutrient addition and gastropods on epiphyte biomass in the Elsdon trial 63

Table 3.8: Results of two-way ANOVA examining the effects of nutrient addition and gastropods on $\Delta$ shoot density in the Browns Bay trial

Table 3.9: Results of two-way ANOVA examining the effects of nutrient addition and gastropods on $\Delta$ shoot density in the Elsdon trial .65

Table A2.1: Summary of species collected during 2016 .......................................... 108

Table A3. 1: Treatments for the Browns Bay trial .................................................... 110

Table A3.2: Treatments for the Elsdon trial................................................................ 110 


\section{General Introduction}

Seagrass meadows, along with salt marshes and mangroves, are ecologically significant coastal ecosystems, where the foundational species are angiosperms (Duarte, 2002). They provide habitat and feeding grounds for many commercially and ecologically important marine species at some point in their life cycle (Connolly, 1994; De Angelo et al., 2014; Flaherty et al., 2014). Seagrass meadows provide vital 'ecosystem services' such as sediment stabilisation and prevention of coastal erosion (Bryan et al., 2007; Gacia and Duarte, 2001). Seagrass usually grows in sheltered lagoons or estuaries with soft sediment and low wave energy, but can also be found on rocky shores. Depending on the species and local water clarity, seagrass can grow intertidally or subtidally.

Seagrasses are clonal organisms, expanding meadows through asexual reproduction until they reach inhospitable conditions. Sexual reproduction, via buoyant seeds, facilitates long distance dispersal and colonization. The root/rhizome portion of seagrass is important for anchoring the plant, drawing nutrients and stabilising sediment. Meadows are disturbed or destroyed by both natural and anthropogenic impacts, such as changes in temperature or salinity, light limitation and/or abrasion from increased turbidity, pollutants, or disruption of the seabed (e.g. dredging) (reviewed by Short and Wyllie-Echeverria 1996). Like coral reef and mangrove systems, seagrass meadows are also threatened by anthropogenic inputs and climate change associated phenomena (Duarte, 2002).

Seagrasses occur worldwide in both temperate and tropical systems, and include several genera, including Zostera, Thalassia, Halodule, Halophila and Posidonia. These genera, and the species within, differ in morphology, physiological adaptations, and resilience to stressors. For example, Halodule spp. are shallow-water species (<10 m) often with short blades (e.g. to $20 \mathrm{~cm}$ for $\mathrm{H}$. wrightii (Creed, 1997)), whereas Posidonia oceanica can grow at depths of up to $80 \mathrm{~m}$ (depending on light conditions) and have blades up to $120 \mathrm{~cm}$ long (reviewed by Gobert et al. 2007). P. oceanica blade pigments also absorb more light (88.5\%) than other seagrass species (e.g. $H$. wrightii 49.8\%, Thalassia testudinum $60.2 \%$, or Z. noltii 71.1\% (Enríquez et al., 1992)), enabling greater light utilisation. 
Seagrass blades play a large role in sediment retention, facilitating sediment settlement and changing the depth profile of currents (Bryan et al., 2007). For example, Posidonia oceanica meadows can retain $300 \%$ more sediment than unvegetated areas (Gacia and Duarte, 2001). In an otherwise bare mud flat system, seagrass blades provide above-ground, three-dimensional habitat for many invertebrates and substrate for microalgal and diatom growth. Gastropods (e.g. Jujubinus striatus ), amphipods (e.g. Gammarus spp.) and isopods (e.g. Erichsonella spp.) graze microalgae that grow on the blades (Gacia et al., 2009; Jeong et al., 2012; Olsen et al., 2011). Some whelks and mud snails (such as Bittium spp. or Smaragdia spp.) consume living or dead blades and other detritus (Gacia et al., 2009; Holzer et al., 2011). Other whelks and crabs prey upon these invertebrates, and are in turn consumed by fish (e.g. flounder) which live in and around the meadows. Megaherbivores such as swans, manatees, turtles and herbivorous fish also consume seagrass tissues and may cause extensive damage to the beds, though the severity of this is debated (Christianen et al., 2012; Dos Santos et al., 2012, 2013; Tulipani and Lipcius, 2014).

The complex habitat created by seagrass supports substantially more species than unvegetated areas (Connolly, 1994; De Angelo et al., 2014; Heck et al., 1995), and provides a refuge which reduces predation of invertebrates by many predators (Carr and Boyer, 2014; Farina et al., 2009; Peterson, 1982; Young et al., 1976). Seagrass meadow degradation is strongly correlated with declines in associated species abundance, diversity, and richness (Bloomfield and Gillanders, 2005), which can have severe consequences for the entire system (Gartner et al., 2010). Highly diverse communities have more connections within trophic groups, so the loss of species due to changes in environmental conditions results in a weakening of overall trophic stability (Blake and Duffy, 2012).

\section{Seagrass - Algae Interactions}

There are two types of algae in seagrass meadows: Macroalgae, such as Enteromorpha or Gracilaria, which grow amongst the seagrass in the mud, and epiphytic algae (diatoms and small algae) which grow on seagrass blades, gastropod shells, etc. Algal epiphytes are a common and natural occurrence on seagrass blades, and can even 
provide seagrass with some protection against ultraviolet radiation (UV) and desiccation (Boese et al., 2003). One of the primary interactions between seagrass and algae is competition for light, as both seagrass and algae rely on photosynthesis for their energetic requirements (Thomsen et al., 2012). Grazing reduces this competition, but also presents another constraint when the density of one promotes increased grazer biomass that results in elevated consumption of the other (i.e. apparent competition) (e.g. Whalen et al.,, 2013). However, algae are capable of colonising smaller spaces - such as the shell of a bivalve, whelk or limpet as well as seagrass blades. This ability to colonise smaller areas opportunistically is balanced by the lower structural complexity of algae compared to seagrass, which makes algae more palatable to certain invertebrate grazers (reviewed by Valentine et al., 2002).

Epiphytic algae growing directly on the seagrass blades can severely hinder seagrass growth and survival by absorbing light before it reaches the seagrass, as both utilise similar light wavelengths (reviewed by Orth and Van Montfrans 1984). The effects of these epiphytic algae can be mitigated by grazers that consume them (e.g. amphipods, isopods and gastropods). However, the presence of these grazers can cause grazerresistant algae to become the dominant form which further increases shading of seagrass blades (Duffy et al., 2003; Norberg, 2000). Herbivorous detritivores (e.g. Bittium varium) which prefer epiphytic algae and diatoms to detached seagrass blades will increase in density during periods of high blade loss, and significantly increase epiphyte removal (Whalen et al., 2013). The 'winner' in these situations is determined by a combination of stochasticity and the differing life history strategies employed by these species. Algae are opportunistic and fast growing, whereas seagrass is slower growing and therefore slower to respond to ideal conditions. However, as stated above, algae are a highly palatable, easily consumed, and easily digested food source, whereas the greater structural complexity of seagrass produces a better defence against generalist herbivores.

\section{Invertebrate Grazers}

Despite their seemingly innocuous size, small invertebrates are known to play important roles in seagrass systems (Cook et al., 2011; Duffy et al., 2003; Ebrahim et al., 2014; Gacia et al., 2009; Whalen et al., 2013). For example, amphipod exclusion 
substantially increases epiphyte loads on seagrass blades (Cook et al., 2011; Ebrahim et al., 2014; Whalen et al., 2013). The removal of epiphytes from seagrass blades is the most common interaction between seagrass and invertebrates, indirectly benefiting seagrass health. Amphipod community composition has been used as an indicator of seagrass health in Eastern Tunisia (Zakhama-Sraieb et al., 2006). While some invertebrates can also graze directly on attached (i.e. living) or dead (as detritus) seagrass blades, this usually occurs when epiphyte biomass is low (Hay et al., 2004). Amphipods and isopods (Phylum: Arthropoda, Subphylum: Crustacea) are common representatives of epiphytic herbivores, and have been relatively well-studied. This is due to their importance and abundance in seagrass meadows worldwide, their position near the base of the food chain, and the ease of excluding them without using cages (e.g. Poore et al., 2009). One of the consequences of multiple amphipod species occurring within seagrass beds is niche partitioning of resources. For example, some amphipods consume detritus and epiphytes (Gammaropsis japonicas and Jassa slatteryi), while others consume mesozooplankton and detritus (Pontogeneia rostrata and Monocorophium acherusicum) (Jeong et al., 2012). Such differences in trophic roles contribute to stronger trophic dynamics within the seagrass bed (Duffy, 2006). Little is known about the trophic interactions between invertebrates and their competitors and predators within seagrass beds. The best studied interaction occurred after the invasive amphipod Amphithoe valida devastated seagrass meadows of San Francisco Bay, consuming both reproductive and vegetative seagrass tissue instead of algae as it does in its native range (Douglass et al., 2011). It was concluded that the combination of lower epiphytic algae on seagrass blades and the absence of predators specialised to prey upon $A$. valida had resulted in the high rates of direct seagrass herbivory observed in the non-native range (Carr and Boyer, 2014; Reynolds et al., 2012).

As stated previously, gastropods have been observed to consume seagrass or algae, depending on resource availability and gastropod species. For example, the gastropod Smaragdia viridis can damage up to $50 \%$ of the daily leaf production of Thalassia testudinum, while the co-occurring snail Modulus modulus consumes epiphytes and periphyton (a mixture of bacteria, algae and diatoms) associated with the seagrass 
blades (Holzer et al., 2011). Gastropod grazers are understudied in seagrass systems despite previous studies demonstrating their ability to play a large role in epiphyte regulation. In Australian P. sinuosa meadows, Jernakoff and Nielsen (1997) found a $44 \%$ reduction in epiphyte biomass due to gastropod grazing, where amphipods altered only epiphyte assemblage composition. Reynolds et al. (2015) reported epiphytic control by a grazer community dominated by the turret shell Bittiolum alternatum in West Falmouth Harbour, Massachusetts. Furthermore, Hily et al. (2004) found a positive indirect effect of gastropod grazers on seagrass biomass via epiphyte removal. The two gastropod species investigated (Jujubinus stratius and Gibbula umbillicalis) concentrated their feeding effort on the tips of blades, an area prone to colonization by long filamentous algae. The removal of this algae reduced shading, which increased seagrass biomass. A review of seagrass, epiphyte and micro-grazers by Orth and Van Montfrans (1984) highlights the importance of gastropod grazers in removing epiphytes from both seagrass and saltmarsh blades, though research was recognised to be lacking.

Declines in the seagrass meadows (Z. noltii) of Southern Portugal from nutrient addition and increasing temperatures have sparked a great deal of research to aid monitoring and management efforts, including surveys of the associated grazers. Most research on gastropod grazers comes from this region, including information on community composition, basic ecology of the dominant species (Hydrobia ulvae), and the interactions between grazers and epiphytes (Cardoso et al., 2002; Cardoso et al., 2004; Lillebo et al., 1999). While gastropods may not be as important in global seagrass systems as crustaceans, it is surprising that so little is known about these often numerically abundant grazers.

Epiphyte removal can have negative effects on the wider system, as epiphytes contribute to nutrient cycling (e.g. nitrogen and phosphorus) (Reynolds et al., 2015). However, the effectiveness of epiphyte removal by invertebrates is spatially and seasonally variable, as demonstrated by the often conflicting results of studies investigating the driving forces behind epiphyte abundance (Bourque and Fourqurean, 2014; Hily et al., 2004). A study by Whalen et al. (2013) goes some way towards addressing this in a Z. marina bed, with a factorial design of nutrient addition (through 
slow release fertilizer) and grazer presence (using slow release carbyl insecticide to exclude amphipods and isopods). The authors suggested that feedback loops alternate between top-down and bottom-up forcing between seasons, finding evidence of amphipod decline in autumn enabling an increase in epiphyte biomass and decline in seagrass cover. A similar occurrence was observed the following summer, when slowrelease insecticide excluded amphipods, and led to a $447 \%$ increase in epiphyte loading, with subsequent declines in seagrass cover. However, their estimates of epiphyte biomass were based on "a single eelgrass shoot from the periphery of each plot" which fails to take into account the potential spatial heterogeneity in epiphyte cover, as well as failing to account for any edge effects of treatments. Furthermore, by excluding only amphipods and isopods, the team did not account for the myriad of impacts that other invertebrates may have on the system.

\section{The Complications of Eutrophication}

Eutrophication, the addition of nutrients such as nitrogen and phosphorus to the marine environment, is a widespread problem that seagrass meadows face, with cascading effects for the associated community. Even under non-eutrophic conditions, loss of seagrass and epiphytes due to reduced light conditions (as may occur with high sediment suspension or floating diatom mats) can lead to a substantial decrease in herbivorous amphipods, isopods and gastropods, such as in an Amphibolis griffithii meadow in Western Australia (Gartner et al., 2010). In nutrient-limited systems, short term nutrient input via eutrophication can increase seagrass production (Irlandi et al., 2004), whereas prolonged exposure can increase algal biomass, which shades seagrass (Deegan et al., 2002). Both short and long term exposure can therefore exacerbate natural seasonal variations in seagrass cover, which fluctuates due to variations in UV exposure during low tide and light penetration while submerged (Turner and Schwarz, 2006; Wong et al., 2013).

Species abundance and community structure of invertebrates associated with seagrass blades can decrease under eutrophic conditions, even when the seagrass itself remains unaffected (Daudi et al., 2012). This can cause cascading effects throughout the system, such as those observed in a Tanzanian estuary polluted by sewage: when compared to a nearby estuary without sewage inputs, there was a significant decrease 
in blade-associated invertebrates and diatoms in the polluted estuary (Daudi et al., 2012). However, the authors acknowledged that the effects of the currents created by the sewage outfall, as well as the possible presence of heavy metals, could not be separated from those of the nutrient addition alone. These invertebrates are at the base of the food chain, and their loss could have significant effects for higher taxa (Bloomfield and Gillanders, 2005; Daudi et al., 2012; Gacia et al., 2009).

There is conflicting evidence of whether micro- and meso- grazers have any effect on increased epiphyte loads under eutrophic conditions: For example, turtle grazing in tropical seagrass systems can reduce the effects of eutrophication by stimulating plant growth, resulting in increased nutrient uptake by the plant to facilitate growth (Christianen et al., 2012). Jorgensen et al. (2007) utilised a naturally occurring nutrient gradient across three adjacent Z. marina meadows in San Quinten Bay (Mexico), finding high mesograzer (i.e. gastropod, amphipod, isopod) abundance associated with low epiphyte biomass in both summer and winter at three sites (high, mid and low nutrient concentrations.) They also found, however, that at the site with the lowest nutrient concentrations, direct consumption of seagrass blades likely plays a large role in system dynamics.

In contrast, Blake and Duffy (2012) factorially manipulated water temperature, eutrophication and grazer diversity (two amphipods (Gammarus mucronatus and Elasmopus levis) and an isopod (Erichsonella attenuata)), concluding that while increased grazer diversity significantly reduced epiphyte loading, it did not affect seagrass or macroalgal biomasses. Gacia et al. (2009) also demonstrated this, finding no effect of high epiphyte-grazing intensity by amphipods, isopods or gastropods on seagrass in high nutrient conditions. However, both of these studies used lab-based experiments, so grazers may have had sufficient access to epiphytic material, or the species used may simply not change from epiphyte to seagrass consumption and therefore did not switch to blade consumption. There is very little research on the trophic dynamics of such switching, such as the effects further up the food chain, or whether non-predatory species interactions influence the change. 


\section{Seagrass in New Zealand}

Due to their phenotypic plasticity, some of the species in these genera are being consolidated as genetic analyses reveal them to be genotypically similar. One such example is the single seagrass species of New Zealand, formerly known as Zostera novozelandica. It was reclassified in 2003 as belonging to the Australasian species $Z$. capricorni (Les et al., 2002). Though debateable, the taxon has subsequently been classified as a sub-species of the Australian Z. muelleri (reviewed by Moore \& Short, 2007). Z. capricorni and Z. muelleri are genetically synonymous (Les et al., 2002), but there is an ongoing debate as to which to use when referring to New Zealand versus Australian seagrass (i.e. both Z. muelleri, or New Zealand's seagrass being $Z$. capricorni). This thesis will refer to both as Z. muelleri.

Z. muelleri occurs along coasts throughout New Zealand, including Stewart Island (the species' southern-most range extent) (Green and Short, 2003). The majority of reported studies have been conducted in the upper North Island, particularly down the east coast (Matapouri to Tauranga). 12 to $23 \%$ of total area in the Whangamata, Wharekawa, Whangapoua and Tauranga Harbours (east coast of upper North Island) are covered in seagrass (Park, 2016; van Houte-Howes et al., 2004). The Papanui Inlet and Kaikoura Peninsula have also been studied, but there seem no definitive reports on cover in these southern sites. Most seagrass meadows in New Zealand occur in the intertidal. Zostera is a small bladed genus, occurring at depths of up to $5 \mathrm{~m}$ below chart datum in the subtidal Slipper Island meadows (Schwarz et al., 2006).

There appears no previous reported research on effects of epiphytic algae or invertebrates at these New Zealand sites. Most studies on seagrass since the year 2000 have focused on the effects of light, temperature and sediment characteristics on seagrass growth and recovery (e.g. Bulmer et al., 2016; Kohlmeier et al., 2014; Matheson and Schwarz, 2007; Schwarz, 2004; Turner, 2007; Turner and Schwarz, 2006), reproduction and genetic diversity (e.g. Cabaco and Santos, 2012; Jones et al., 2008; Les et al., 2002) and the importance as a habitat for fish (e.g. Morrison et al., 2002; Parsons et al., 2013, 2014, 2015, 2016). There have also been several studies on invertebrate assemblages (Alfaro, 2006a; Battley et al., 2011), with a focus on edge effects and/or seagrass density on these communities (Leduc and Probert, 2011; Mills 
and Berkenbusch, 2009; van Houte-Howes et al., 2004) and isotopic analyses on grazer diets (Alfaro et al., 2006; Leduc et al., 2009; Leduc et al., 2006).

Te Awarua-o-Porirua Harbour (the Porirua Harbour) is one of New Zealand's largest estuaries, located in the south of the North Island of New Zealand (Figure 1.1). The harbour consists of two arms, the Onepoto Arm near the industrial city centre, and the Pauatahanui Arm surrounded by farm land and ongoing suburb development. Both arms contain seagrass (Z. muelleri), with a total of 18 ha of seagrass meadow in the Onepoto Arm (6\% of area), and 27.7 ha in the Pauatahanui Arm (5\% area) (Stevens and Robertson, 2013). Similar to other meadows around the world, seagrass in the Porirua Harbour is impacted by anthropogenic inputs, as are the fauna associated with them. While there have been several surveys of the seagrass itself and abiotic influences in recent years (Duncan, 2015; Matheson and Wadha, 2012; Stevens and Robertson, 2013, 2014; Stevens and Robertson, 2016), none have been conducted on any of the associated grazers. The Greater Wellington Regional Council and the Porirua City Council have ongoing management strategies to improve the health of the Porirua Harbour, with emphasis on the seagrass.

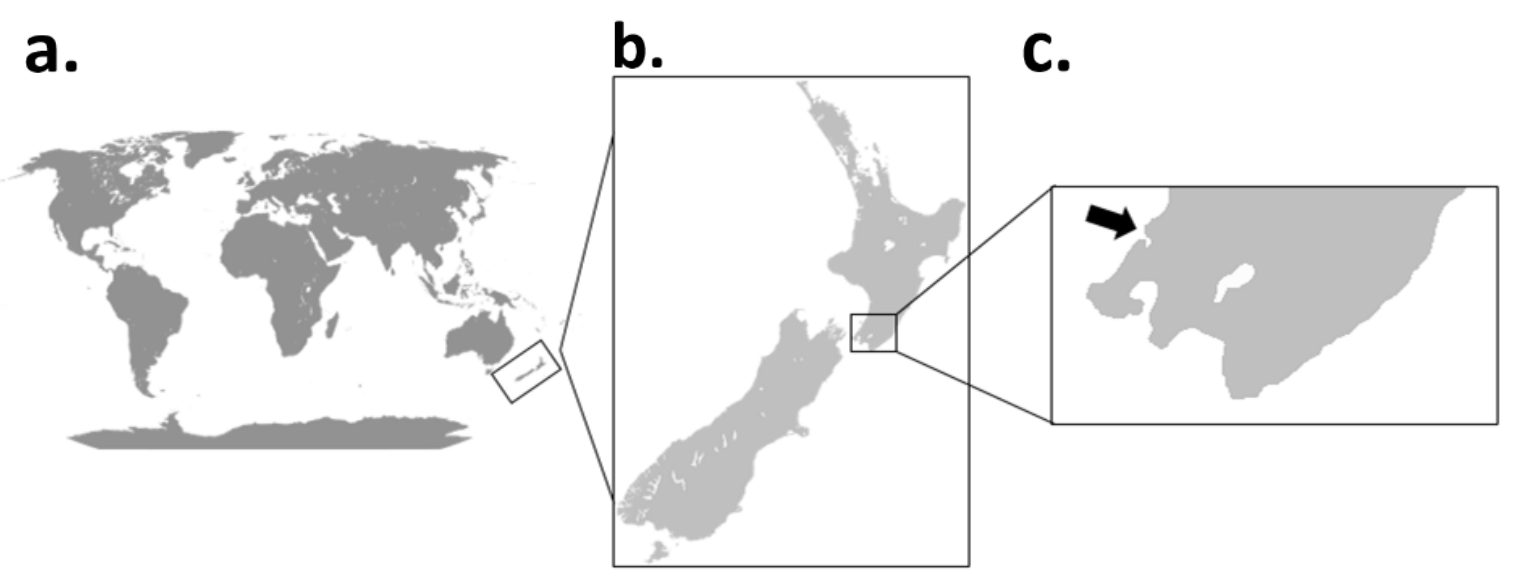

Figure 1.1: Location of the Porirua Harbour. (a) The map of the world shows the location of (b) New Zealand, with (c) arrow indicating the Porirua Harbour.

\section{Conclusion and Aims of Research}

Seagrass beds are recognised as an important marine habitat, providing food sources and reducing predation threats, as well as providing ecologically important services such as sediment stabilisation and nutrient cycling. The health and structure of these beds can be significantly altered by the often complex direct and indirect interactions between invertebrates, epiphytes and the seagrass itself. Herbivorous gastropods are 
often overlooked in favour of amphipods and isopods, despite their demonstrated importance (Alfaro, 2006a; Cardoso et al., 2002; Cardoso et al., 2004; Gacia et al., 2009; Hily et al., 2004; Jernakoff and Nielsen, 1997; Kharlamenko et al., 2001; Lillebo et al., 1999). These crustaceans are arguably the most important invertebrate grazers in many seagrass ecosystems, but the bias may also be due to the changeable nature of gastropod interactions with seagrass. For example, while the behaviour of $A$. valida in consuming epiphytes in one area and seagrass in another is novel for the species, gastropods may consume algae or seagrass depending on the gastropod species and the availability of either food source.

Most of the references in this review have been taken from international studies (particularly Australia and the USA), due to the lack of comparable information on these interactions in New Zealand. While New Zealand's seagrass species (Z. muelleri) also occurs in Australia, seagrass has extremely high phenotypic flexibility, and the invertebrate, epiphyte, and seagrass assemblages will differ drastically between the two countries. More research is required to tease these interactions of seagrass, grazing species and epiphytic algae apart and gain a fuller understanding of the dynamic interactions within seagrass systems in New Zealand environments, and to design more accurate lab studies. Inputs to the marine environment (such as eutrophication) confound trends and observations from field-based studies, hindering our ability to understand the processes occurring. Laboratory-based studies allow more control over influences, but in doing so can over-simplify the system, and may remove important influences which alter the patterns observed.

There has been little research into the interactions between biotic and abiotic components of seagrass communities, particularly in the context of anthropogenic impacts, in the Southern Hemisphere. This thesis explores the interactions between seagrass and associated gastropod communities over spatial and seasonal scales in a large estuary, as well as under controlled eutrophic conditions in the laboratory. The first chapter examines the spatio-temporal variability in associated gastropods and relationships with seagrass and epiphyte biomass, in a large, temperate estuary. The second chapter details the experimental study of seagrass and epiphyte responses to nutrient addition and gastropod grazers, using plots of seagrass transported from 
polluted and non-polluted sites. Such knowledge should also improve conservation and management efforts to keep seagrass beds healthy in the face of increasing anthropogenic inputs. 


\title{
2. Temporal and Spatial Variation in Seagrass Associated Gastropod Communities of
}

\author{
the Porirua Harbour.
}

\section{Abstract}

The aim of this chapter is to examine seagrass-associated gastropod communities across spatial and temporal scales in a large tidal New Zealand estuary that has several smaller bays within it that vary in abiotic conditions and seagrass attributes. Field surveys were conducted in 2016 at three sites (Browns Bay, Paremata Station, Elsdon) in the Porirua Harbour, across two seasons (summer and winter), and at two tidal heights (high and low). Seagrass blades were clipped at the mud surface within eight $0.25 \mathrm{~m}^{2}$ quadrats per tidal height to determine above-ground biomass. A sub-sample of blades was taken to estimate average blade area and epiphyte presence. Invertebrates present on the blades were also collected and identified. Potamopyrgus estuarinus, Notoacmea scapha, Diloma spp. and Micrelenchus spp. were the numerically dominant gastropod grazers in the harbour. Gastropod densities were spatially and temporally variable, but densities of almost all species peaked in summer. $N$. scapha and P. estuarinus were the most numerically abundant gastropods. The latter dominated Paremata Station in both summer and winter, but occurred at low densities elsewhere. N. scapha peaked at Browns Bay in summer, but occurred in similar densities between sites during winter. The winter decrease of gastropod density corresponded with increased epiphyte presence. Blade area increased in winter at all three sites, suggesting a response to reduced light availability. Sites showed inconsistent trends in biomass between seasons, with above-ground biomass at Elsdon significantly decreased in winter, while Paremata Station slightly decreased, and Browns Bay showed an even smaller increase. This study has demonstrated the high variability in seasonal seagrass characteristics as well as the associated epiphyte and gastropod communities at relatively small spatial scales (i.e. within sites and among sites a few kilometres apart), and improved knowledge of intra-annual variations in the Porirua Harbour. 


\section{Introduction}

Seagrass is a dynamic living habitat that varies spatially and temporally, often in response to abiotic factors (Clausen et al., 2014; Gacia and Duarte, 2001; Hasegawa et al., 2008; Kim et al., 2012; Nelson and Waaland, 1997; Wong et al., 2013). One major spatial gradient in physical stress is tidal height. Variation across tidal height is primarily driven by physical stress at the terrestrial margin from UV/light intensity, desiccation and temperatures, and possibly interactions with macrograzers like waterfowl (Dos Santos et al., 2012). Nutrients, sedimentation and other environmental variables are important drivers of variability at larger scales. Even between relatively close bays, magnitudes and types of inputs can vary (e.g. Eldridge and Morse, 2000; Miller et al., 2005; Thormar et al., 2016). In terms of temporal variability, seasonal changes in light, temperature, and nutrient availability will play an important role in driving growth and mortality. Changes in blade size and/or density often reflect on-going environmental conditions, such as turbidity and blade abrasion (Miller et al., 2005) or nutrient availability and corresponding epiphyte densities (Cabaço et al., 2013).

Meadows are home to many organisms, providing food, refuge and nursery grounds to fish and crustaceans (Attrill et al., 2000; Bloomfield and Gillanders, 2005; Connolly, 1994; Heck et al., 1995; Heck et al., 2003; Parsons et al., 2013; Parsons et al., 2016). Avian, reptilian, mammal and invertebrate species are known to directly consume seagrass tissues (Dos Santos et al., 2012, 2013; Skilleter et al., 2007; Tulipani and Lipcius, 2014; Zimmerman et al., 2001), or associated detritus (Jeong et al., 2012; Leduc et al., 2009). Other grazers, typically crustaceans and gastropods, consume epiphytic algae growing on the blades (Hily et al., 2004; Jernakoff and Nielsen, 1997). Epiphytic communities follow a predictable colonization pathway, beginning with diatoms and foraminifera priming the surface for larger algal and sessile invertebrate species (e.g. bryozoans) (Piazzi et al., 2016). While epiphytic algae often reduce light availability to seagrass blades, they are an important link in the food web of seagrass systems.

One important group of understudied grazers associated with seagrass are microgastropods (limpets and snails $<10 \mathrm{~mm}$ ) living on the blades. Although they can be 
numerous little research has been conducted on them, with the exception of some studies in Europe (e.g. Almeida et al., 2008; Blanchet et al., 2004; Dolbeth et al., 2003; Malaquias and Sprung, 2005; Sprung, 1994). This lack of attention is largely due to the view that, compared to amphipods, their lower densities and consumption rates have a limited impact on epiphyte control.

Southern Hemisphere micro-grazer communities have been poorly characterized, and nothing is known of their spatial and temporal variability. Due to the dynamic nature of seagrass habitats, including the epiphytes (e.g. Clausen et al., 2014; Hily et al., 2004), invertebrate communities may be dynamic as well. There is little knowledge on what scales they will vary, or how tightly linked they are to changes in the seagrass itself, even in the Northern Hemisphere literature. For example, in addition to the seagrass itself, micro-grazer community structure may be due to biotic interactions such as competition or predation (competition: Brenchley, 1982; Edgar, 1990; predation: Ollivier et al., 2015; both: McCloskey and Unsworth, 2015), tolerance to abiotic/physical stress (Ahrens and Hickey, 2002; Winterbourn, 2016) and the role that seagrass may play in ameliorating some of those physical stresses (such as providing shade or reducing desiccation (Penhale and Smith, 1977)).

The Porirua Harbour is one of New Zealand's largest estuaries. Several of the bays contain seagrass meadows, which vary in morphology and cover (Duncan, 2015; Matheson and Wadha, 2012). The topography and magnitudes of inputs also vary between these bays (Figure 2.1). Elsdon, located at the mouth of the Porirua Stream, is exposed to greater nutrient loads, lower salinities and higher turbidity than the other sites (Matheson and Wadha, 2012). Surprisingly, this site also had high light levels, likely due to the variability of inputs from the Porirua Stream, where changes in water movement allow suspended solids to settle, thereby reducing turbidity (Matheson and Wadha, 2012). Paremata Station has high light availability and greater water exchange via tidal movement than the other sites, and Browns Bay appears to experience low to intermediate light availability with nutrient levels intermediate between Elsdon and Paremata Station (Matheson and Wadha, 2012).

The aim of this chapter is to characterize the invertebrates associated with seagrass, with a focus on micro-gastropods, and to examine how this community varies in 
species composition and abundance over two spatial scales (across tidal heights and across sites with different environmental and seagrass characteristics), and within a year (across summer and winter). I hypothesized that Elsdon, the most polluted site, would have the lowest gastropod densities. Also, that epiphyte growth would exceed grazer control in winter due to seasonal influences such as increased nutrient inputs from terrestrial run-off and the presence of worn blades. 


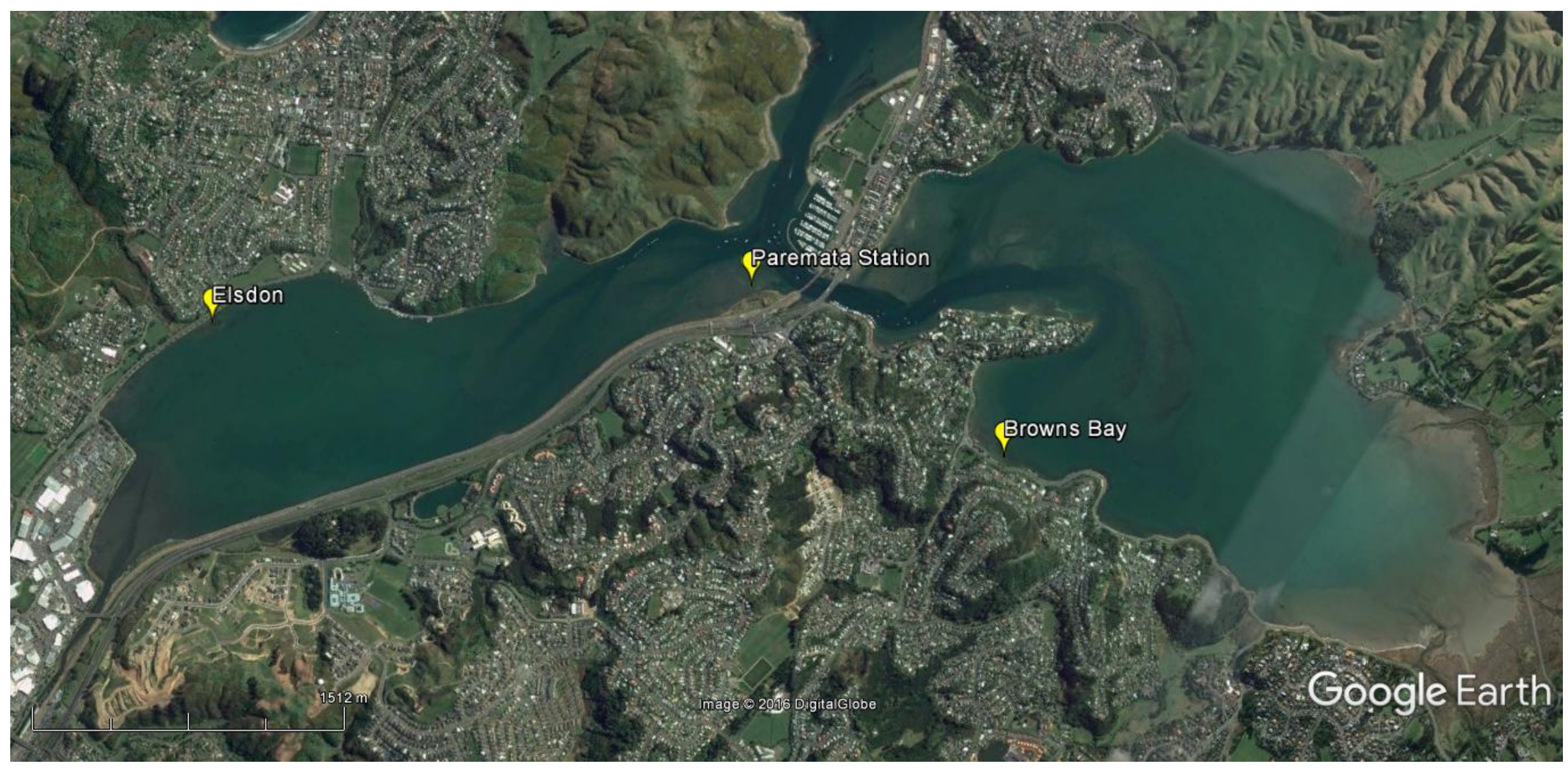

Figure 2.1: Map of sites sampled within the Porirua Harbour: Browns Bay (in the Pauatahanui Arm), Paremata Station and Elsdon (in the Onepoto Arm). Retrieved from Google Earth 17/08/2016. 


\section{Methods}

\section{Sampling from the field}

Seagrass was collected from three sites in the Porirua Harbour (Browns Bay, Paremata

Station and Elsdon) over three to four days in each of summer (22 to 25 January) and winter (18 July to 21 July) 2016, using the same methods each season. At each site, a 50m transect was placed parallel to the shore in the upper area of the meadow near the higher tidal height border, and another in the lower area of the meadow near the low tide mark. The upper transect was positioned at least $0.5 \mathrm{~m}$ down shore of the edge of the meadow to reduce edge effects. Once the transect was positioned, randomly generated numbers were used to determine the point at which a harvester stood. With his or her back to the water, the harvester dropped a quadrat over their shoulder. Eight quadrats $(25 \times 25 \mathrm{~cm})$ were sampled per transect. Quadrats were re-dropped if more than half of the area within it was bare or in a puddle. Photos were taken of each quadrat to record the environmental context. To avoid re-sampling seagrass that had been harvested in summer, and to maintain independence of samples, winter transects were laid slightly down shore of summer positions. While the 5 -month period between sampling events would likely have been sufficient time for harvested patches to re-grow, re-sampling was avoided to maintain independence of samples.

Each quadrat was sampled in two ways (described in detail in following section). First, a sub-sample of 10 blades was taken at random from the quadrat and stored in a ziplock bag for subsequent assessment of morphology and epiphyte presence in the laboratory. Second, all remaining seagrass blades in the quadrat were harvested at mud-level and stored in a separate ziplock bag to assess the associated invertebrate community and seagrass biomass. All invertebrates on the blades were collected, including any that had fallen off during the sampling.

\section{Assessment of seagrass blade traits and epiphytes}

The 10-blade sub-samples for each quadrat were stored in a refrigerator in the laboratory prior to processing. Within 7 days of collection, the sub-sampled blades were rinsed, any invertebrates removed, and the blade lengths and widths measured to $0.01 \mathrm{~mm}$ using Vernier Callipers. Blades were rinsed by soaking them in freshwater for 20 to 30 minutes in 
the bags (causing most invertebrates to fall off), and then tipping these contents over a $1 \mathrm{~mm}$ mesh sieve. Blades were removed from the sieve before it was inverted over a tray and tapped to dislodge any invertebrates. The sieve was then thoroughly checked for any remaining invertebrates. Invertebrates were stored in labelled specimen containers in $70 \%$ ethanol for subsequent identification. Notes on blade condition (i.e. colour and epiphyte presence) were also made, and the presence of any epiphytes noted.

\section{Assessment of seagrass biomass and invertebrates}

Immediately following collection in field, the whole-quadrat samples were rinsed in freshwater over a $1 \mathrm{~mm}$ mesh sieve to remove sediment. Sample bags were also rinsed over the sieve to remove sediment. Blades (in sieve) were shaken to remove excess water before being returned to the appropriate bag and frozen for later processing. Frozen samples were removed from the freezer, filled with tap water, and left to soak for 30 to 40 minutes. Invertebrates were removed and stored in labelled specimen containers with $70 \%$ ethanol. The blades from the whole-quadrat samples were dried in an $80^{\circ} \mathrm{C}$ oven for 48 hours and weighed to determine above-ground dry biomass.

Invertebrates were identified to the species level where possible. Juvenile gastropods in Diloma and Micrelenchus genera are difficult to identify to the species level, so were not included in species-level counts. Diloma and Micrelenchus individuals were classed as juveniles if they were $<5 \mathrm{~mm}$ diameter, as these shells did not have obvious morphological traits and/or colouring to classify to species level. Juvenile and adult counts were recorded separately for Cominella glandiformis, Zeacumantus lutulentus and Haminoea zelandiae. These juveniles were small $(<1 \mathrm{~cm})$, with easily identifiable morphology and/or colouring similar to adults.

Collection methods were not designed to provide representative samples of crustaceans, particularly isopods and amphipods. These crustaceans were more likely to be collected as the tide returned, or if water was retained by dense blades (as was observed at Elsdon and Browns Bay). As crabs were found in almost every sample, they were identified to species level. All species counts are recorded in Table A2.1. Statistical analyses focused on gastropod grazers, as these species live directly on seagrass, and graze biofilm from the blades, thereby slowing epiphyte colonisation (Piazzi et al., 2016). 
Notoacmea species are cryptic, but according to genetic studies, $N$. scapha is the only species to occur on the leaves of Z. muelleri, and also on Diloma subrostrata and Austrovenus stutchburyi shells (Nakano et al., 2009; Nakano and Spencer, 2007). For this reason, all limpets in this study are considered to be N. scapha. Similarly, Potamopyrus estuarinus and $P$. antipodarum are best distinguished by habitat $-P$. antipodarum occurs in freshwater, and $P$. estuarinus in brackish environs. $P$. estuarinus is a detritivore, consuming plant and animal material in sediment, including biofilm. These snails are inactive during exposure at low tide, so their presence on seagrass blades during sampling indicates that they commonly occur on seagrass while submerged (Winterbourn, 2016).

\section{Statistical Analyses}

All analyses were conducted in R V3.3.1 (R Core Team 2016) using RStudio v0.09.99.903 (RStudio Team 2015). Chi-square tests were used to test epiphyte presence/absence on sub-sampled blades, only using those that were classified as $>50 \%$ green. These tests utilized the chisq.test function from the MASS package (Venables and Ripley, 2002).

Permutation ANOVA (PERMANOVA) was used to test whole-quadrat samples using aovp function within the ImPerm package (Wheeler and Torchiano, 2016). Tests were conducted for season, site and tidal height effects (upper and lower transects) on the densities of selected invertebrate species associated with the seagrass blades ( $P$. estuarinus, $N$. scapha, Diloma spp., Micrelenchus spp. and the total number of gastropods (herbivorous and otherwise)) across all three sites. These densities were standardised to count per g of dry seagrass per $\mathrm{m}^{2}\left(\mathrm{~g} \mathrm{DW}^{-1} \mathrm{~m}^{-2}\right)$. PERMANOVA tests were also used to examine effects of site and season on whole-quadrat samples of above-ground biomass and sub-samples of blade area. Post-hoc tests were run using the TukeyHSD function in the multcomp package (Hothorn et al., 2008). Permutation tests run multiple iterations of the model, generating many pseudo-F values which are tested for similarity across iterations (presented as a $p$ value). There are therefore no F-values associated with PERMANOVA tests. Instead a probability that the F-value of any one iteration will fall within the distribution of combined F-values is reported as Pr. This Pr value is interpreted similarly as a p-value, with a 0.05 cut off. The number of iterations that the model runs depends on how many it takes to reach the 'stopping rule'. 
This is based on Anscombe's criterion (Anscombe, 1953), and is reached when:

$$
\text { s.e. } \widehat{p-v a l u e}<0.1<p \text {-value. }
$$

\section{Results}

\section{Seagrass}

Mean above-ground biomass was influenced by tidal height, site and season, as well as a significant interaction between site and season (Table 2.1). Biomass was greater at lower tidal heights (Figure 2.2). Average above-ground biomass tended to be similar between Paremata Station and Browns Bay across seasons and tidal heights (Figure 2.2). In contrast, values at Elsdon were up to 2 times higher in summer than in winter in both tidal heights, likely the main cause of the interaction (Figure 2.2).

Table 2.1: Results of PERMANOVA examining effects of season (summer and winter) and site (Browns Bay, Paremata Station and Elsdon) and tidal height (upper and lower) on seagrass above-ground biomass $\left(\mathrm{g} \mathrm{DW}^{-1} \mathrm{~m}^{-2}\right)$ in the Porirua Harbour.

\begin{tabular}{|l|l|l|l|l|}
\hline Source of Variation & df & Resid. SS & Iterations & $\operatorname{Pr(Prob)~}$ \\
\hline Season & 1 & 1870.6 & 5000 & $<0.0001$ \\
\hline Site & 2 & 15347.5 & 5000 & $<0.0001$ \\
\hline Tidal height & 1 & 10.73 .6 & 5000 & $<0.0001$ \\
\hline Season*Site & 2 & 2552.9 & 5000 & $<0.0001$ \\
\hline Season* Tidal height & 1 & 33.8 & 81 & 0.5556 \\
\hline Site* Tidal height & 2 & 111.5 & 207 & 0.4783 \\
\hline Season*Site* Tidal height & 2 & 20.5 & 51 & 0.9216 \\
\hline Residuals & 84 & 7505.3 & & \\
\hline
\end{tabular}
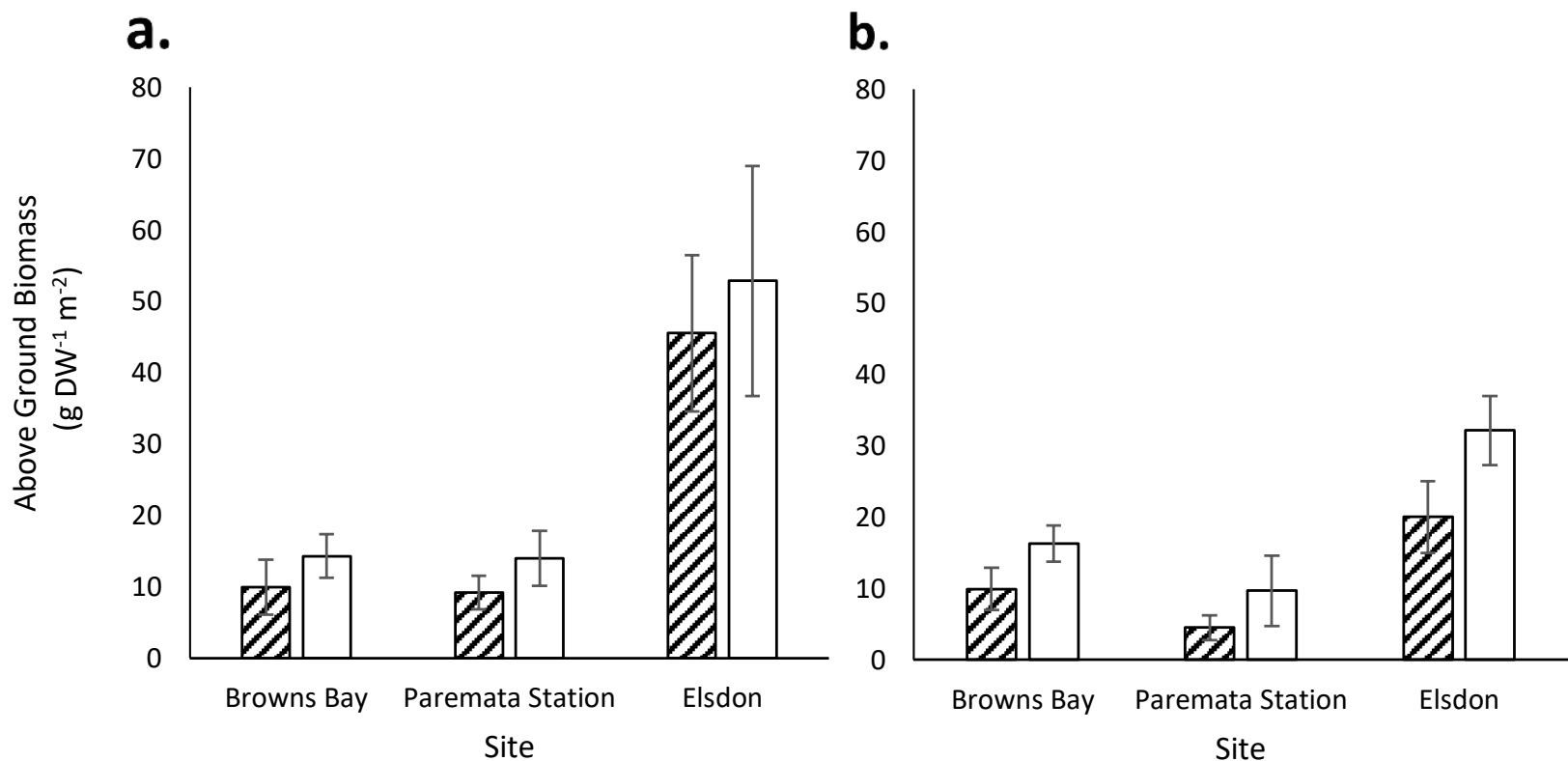

Figure 2.2: Average (+/- $95 \%$ confidence intervals) above-ground biomass of seagrass from sites in Porirua Harbour in (a) summer and (b) winter. Patterned bars represent upper tidal heights; open bars represent lower. $\mathrm{n}=8$ quadrats per tidal height. 
Blade area also had a significant interaction between site and season, season and tidal height, and site, season and tidal height, as well as individual effects of site, season and tidal height (Table 2.2). Blade area tended to increase between summer and winter in the lower tidal heights of Browns Bay and Paremata Station (Figure 2.3). Elsdon had similarly high blade areas in both summer and winter (Figure 2.3). Paremata Station had the lowest blade area of all sites (Figure 2.3). The effect of tidal height varied across sites and seasons. For example, although blade area was greater at all sites in the winter at the lower tidal height compared to higher, in summer blade area was similar across all tidal heights at Browns Bay and Paremata Station (Figure 2.3).

Table 2.2: Results of PERMANOVA examining effects of season (summer and winter) and site (Browns Bay, Paremata Station and Elsdon) and tidal height (upper and lower) on blade area $\left(\mathrm{mm}^{2}\right)$ in the Porirua Harbour.

\begin{tabular}{|l|l|l|l|l|}
\hline Source of Variation & df & Resid. SS & Iterations & $\operatorname{Pr}$ (Prob) \\
\hline Season & 1 & 114290 & 5000 & $<0.0001$ \\
\hline Site & 2 & 2708140 & 5000 & $<0.0001$ \\
\hline Tidal height & 1 & 116627 & 5000 & $<0.0001$ \\
\hline Season*Site & 2 & 26109 & 5000 & $<0.0001$ \\
\hline Season* Tidal height & 1 & 23873 & 5000 & $<0.0001$ \\
\hline Site* Tidal height & 2 & 6667 & 2232 & 0.0632 \\
\hline Season*Site* Tidal height & 2 & 48773 & 5000 & $<0.0001$ \\
\hline Residuals & 938 & 2801910 & & \\
\hline
\end{tabular}

a.

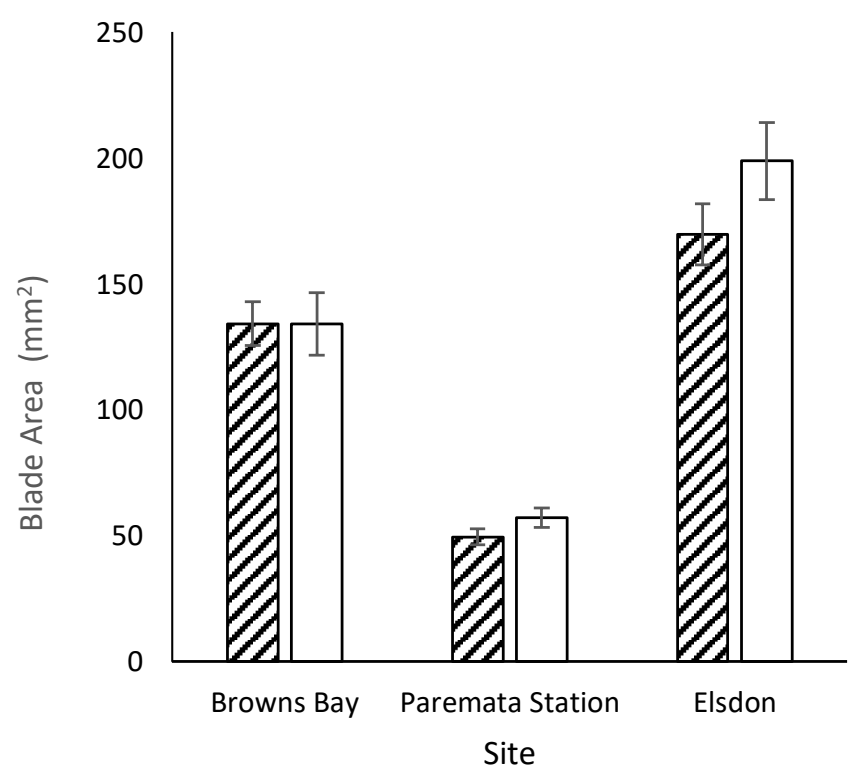

b.

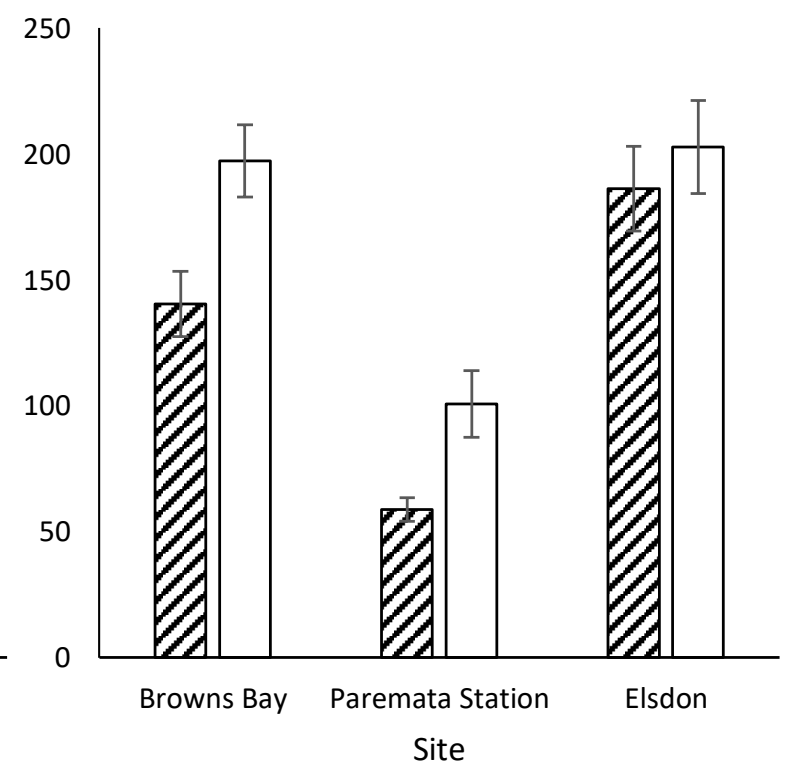

Figure 2.3: Average (+/- 95\% confidence intervals) blade area of seagrass from sites in Porirua Harbour in (a) summer and (b) winter. Patterned bars represent upper tidal heights; open bars represent lower. $n=80$ blades per tidal height. 
When sub-samples were pooled across sites, epiphyte presence was significantly greater in winter ( $62 \%$ of sub-samples) than in summer ( $28 \%$ of sub-samples, Chi-Square test: $\chi^{2}=$ $13.31, \mathrm{df}=1, \mathrm{n}=127, \mathrm{p}$-value $=0.0003$ ). Similarly, $90 \%$ of sub-sample blades collected in winter were more than half green, compared to $74 \%$ in summer (Figure 2.4). Chi-Square tests support a significant difference in predominant blade colour between seasons $\left(\chi^{2}=\right.$ 47.27, $\mathrm{df}=1, \mathrm{n}=127, \mathrm{p}$-value $<0.0001)$.

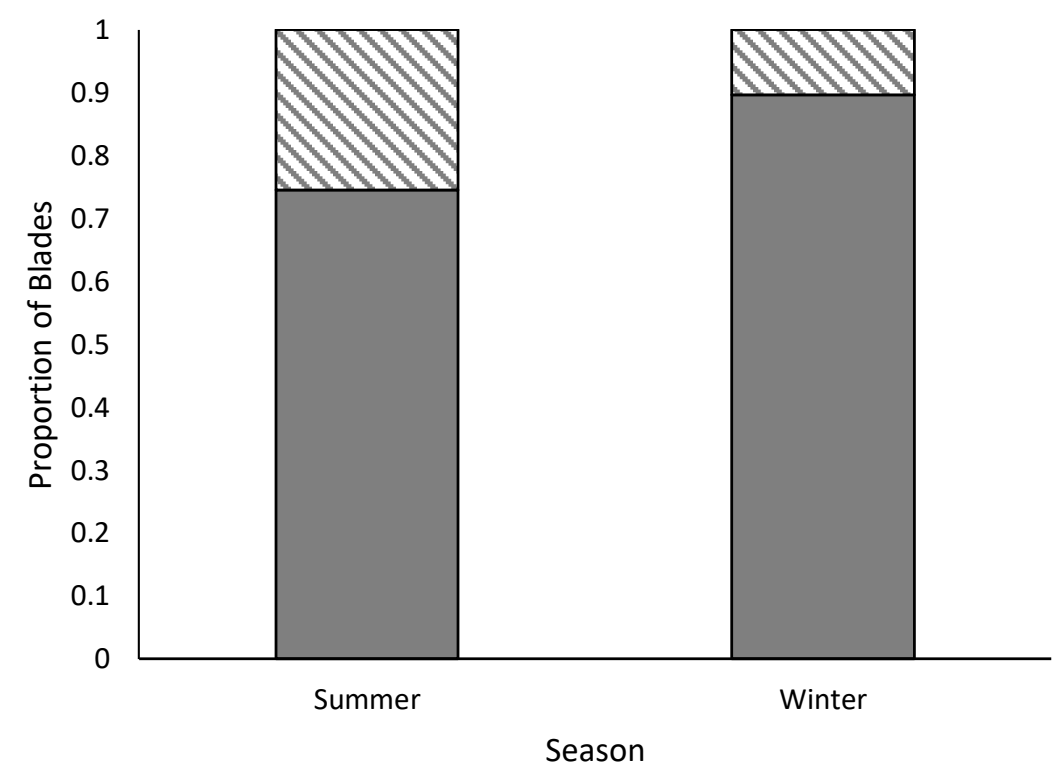

Figure 2.4: Proportion of mostly ( $>50 \%$ ) green blades in summer and winter. Data is pooled across sites. Grey boxes represent 'mostly green' blades, while patterned boxes represent blades which were mostly ( $>50 \%$ ) brown or clear. $n=640$ for summer, $\mathrm{n}=630$ for winter. 


\section{Invertebrates}

A total of 2662 individual organisms from 28 species across 3 phyla were identified over the course of this study (Table A2.1). Many of these species occurred infrequently, or very patchily, or are not grazers (e.g. bivalves). Therefore, analyses focused on the total number of gastropods (herbivorous and otherwise, a total of 15 species), as well as the herbivorous species considered to be numerically dominant ( $>50$ individuals per $\mathrm{g}$ dry seagrass per $\mathrm{m}^{2}$ across both seasons at two or more sites, a total of 4 genera) (Figure 2.5).
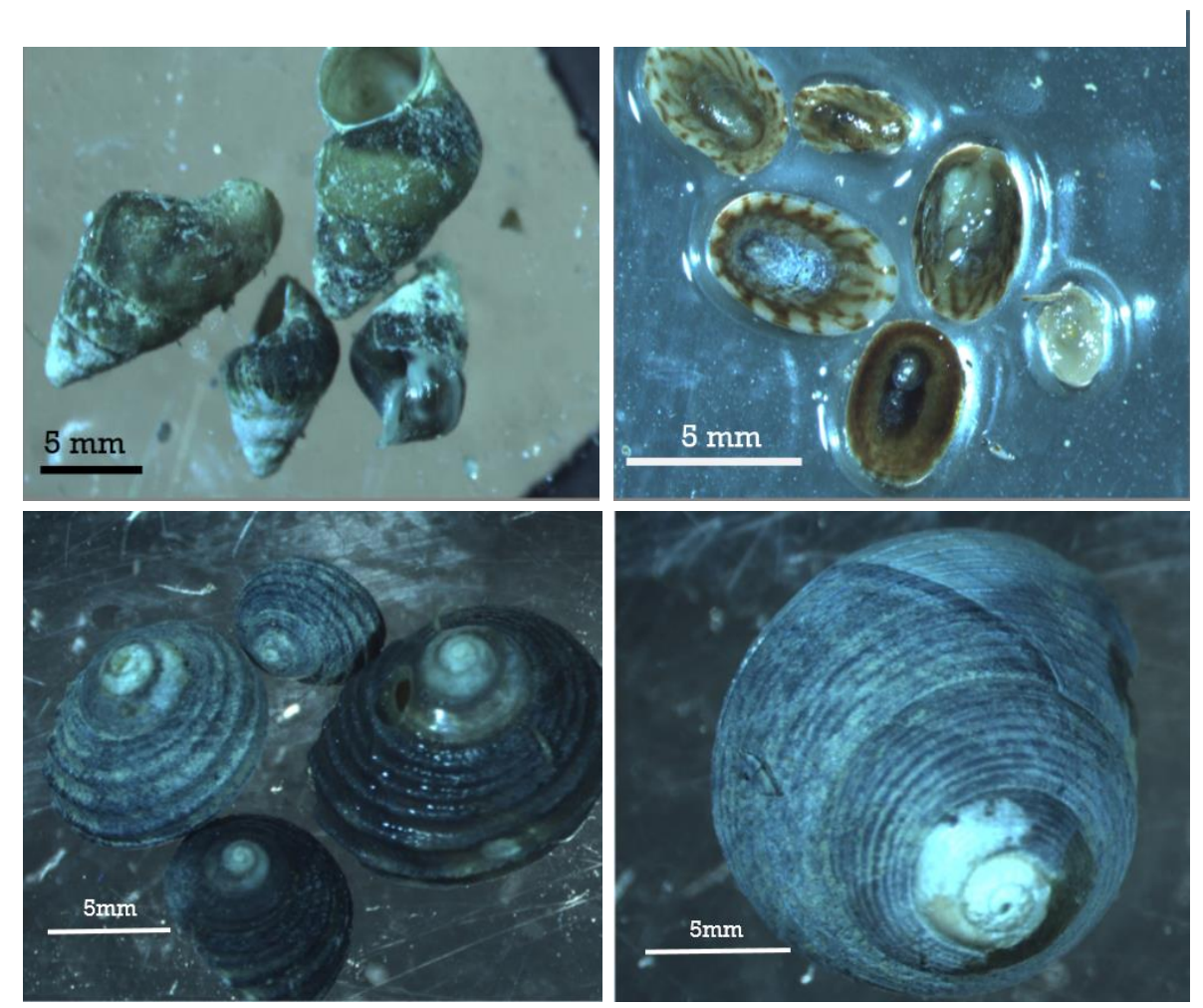

Figure 2.5: Representatives of the four main gastropod genera. Clockwise: Potamopyrgus estuarinus, Notoacmea scapha, Micrelenchus spp., Diloma spp. 


\section{Potamopyrgus estuarinus}

Mean densities of the snail Potamopyrgus estuarinus were highly variable and were significantly affected by site and tidal height and the interactions of all factors, including the three-way interaction (Table 2.3). Densities at Paremata Station were higher than the other sites across seasons and tidal heights, but the lower shore in summer at Paremata Station had much greater densities compared to all other tidal heights (Figure 2.6), with 497 individuals $\mathrm{g} \mathrm{DW}^{-1} \mathrm{~m}^{-2}$. Upper and lower tidal heights at Elsdon and Browns Bay had very low densities ( $<55$ individuals) in both seasons, also there was a slight increase in density at Elson in the lower shore in winter compared to summer.

Table 2.3: Results of PERMANOVA examining effects of season (summer and winter) and site (Browns Bay, Paremata Station and Elsdon) and tidal height (upper and lower) on density of Potamopyrgus estuarinus $\left(\mathrm{g} \mathrm{DW}^{-1} \mathrm{~m}^{-2}\right)$ in the Porirua Harbour.

\begin{tabular}{|l|l|l|l|l|}
\hline Source of Variation & df & Resid. SS & Iterations & $\operatorname{Pr}(\operatorname{Prob})$ \\
\hline Season & 1 & 37453 & 1006 & 0.0905 \\
\hline Site & 2 & 928580 & 5000 & $<0.0001$ \\
\hline Tidal height & 1 & 105616 & 3731 & 0.0263 \\
\hline Season*Site & 2 & 136371 & 2857 & 0.0340 \\
\hline Season*Tidal height & 1 & 112957 & 5000 & 0.0072 \\
\hline Site*Tidal height & 2 & 301705 & 5000 & $<0.0001$ \\
\hline Season*Site*Tidal height & 2 & 167937 & 5000 & 0.0048 \\
\hline Residuals & 84 & 1407246 & & \\
\hline
\end{tabular}
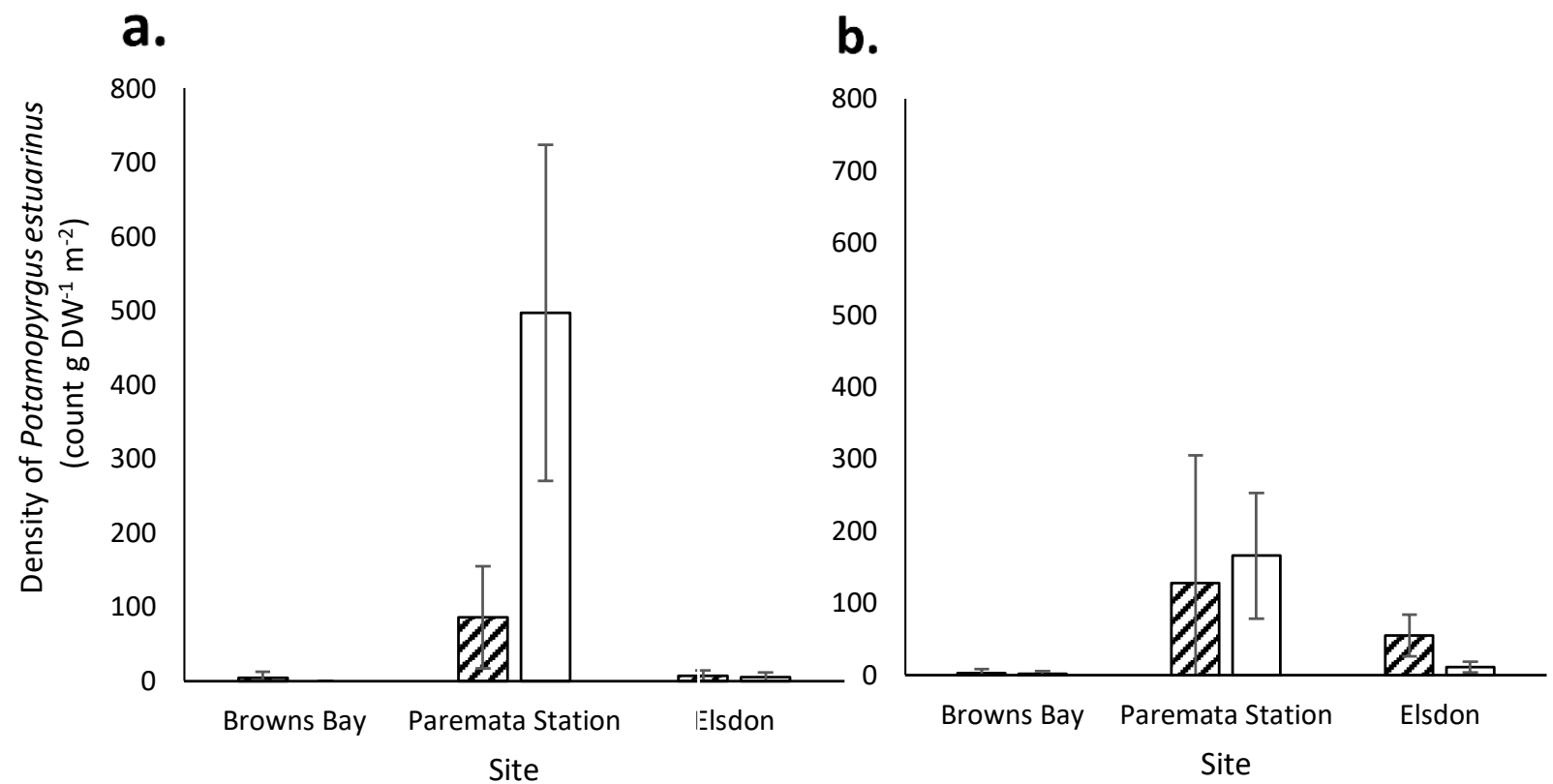

Figure 2.6: Average (+/- 95\% confidence intervals) density of Potamopyrgus estuarinus on seagrass from sites in Porirua Harbour in (a) summer and (b) winter. Patterned bars represent upper tidal heights; open bars represent lower. $\mathrm{n}=8$ quadrats per tidal height. 


\section{Notoacmea scapha}

Densities of the limpet Notoacmea scapha were significantly different at the site and season levels, as well as interactions between all factors, including the three-way interaction (Table 2.4). The summer density at the upper shore of Browns Bay was, on average, 3 to 41 times higher than all other tidal heights (Figure 2.7). Densities of the lower shore in summer and winter, and the high shore in winter, were all similar. N. scapha densities at Elsdon were similar across tidal heights and seasons, whereas densities at Paremata Station were similar across tidal heights but higher in summer than winter.

Table 2.4: Results of PERMANOVA examining effects of season (summer and winter) and site (Browns Bay, Paremata Station and Elsdon) and tidal height (upper and lower) on density of Notoacmea scapha $\left(\mathrm{g} \mathrm{DW}^{-1} \mathrm{~m}^{-2}\right)$ in the Porirua Harbour.

\begin{tabular}{|l|l|l|l|l|}
\hline Source of Variation & df & Resid. SS & Iterations & $\operatorname{Pr}(\operatorname{Prob})$ \\
\hline Season & 1 & 136582 & 5000 & $<0.0001$ \\
\hline Site & 2 & 585438 & 5000 & $<0.0001$ \\
\hline Tidal height & 1 & 77669 & 5000 & $<0.0001$ \\
\hline Season*Site & 2 & 145035 & 5000 & $<0.0001$ \\
\hline Season*Tidal height & 1 & 90428 & 5000 & $<0.0001$ \\
\hline Site*Tidal height & 2 & 352845 & 5000 & $<0.0001$ \\
\hline Season*Site*Tidal height & 2 & 226384 & 5000 & $<0.0001$ \\
\hline Residuals & 84 & 471192 & & \\
\hline
\end{tabular}
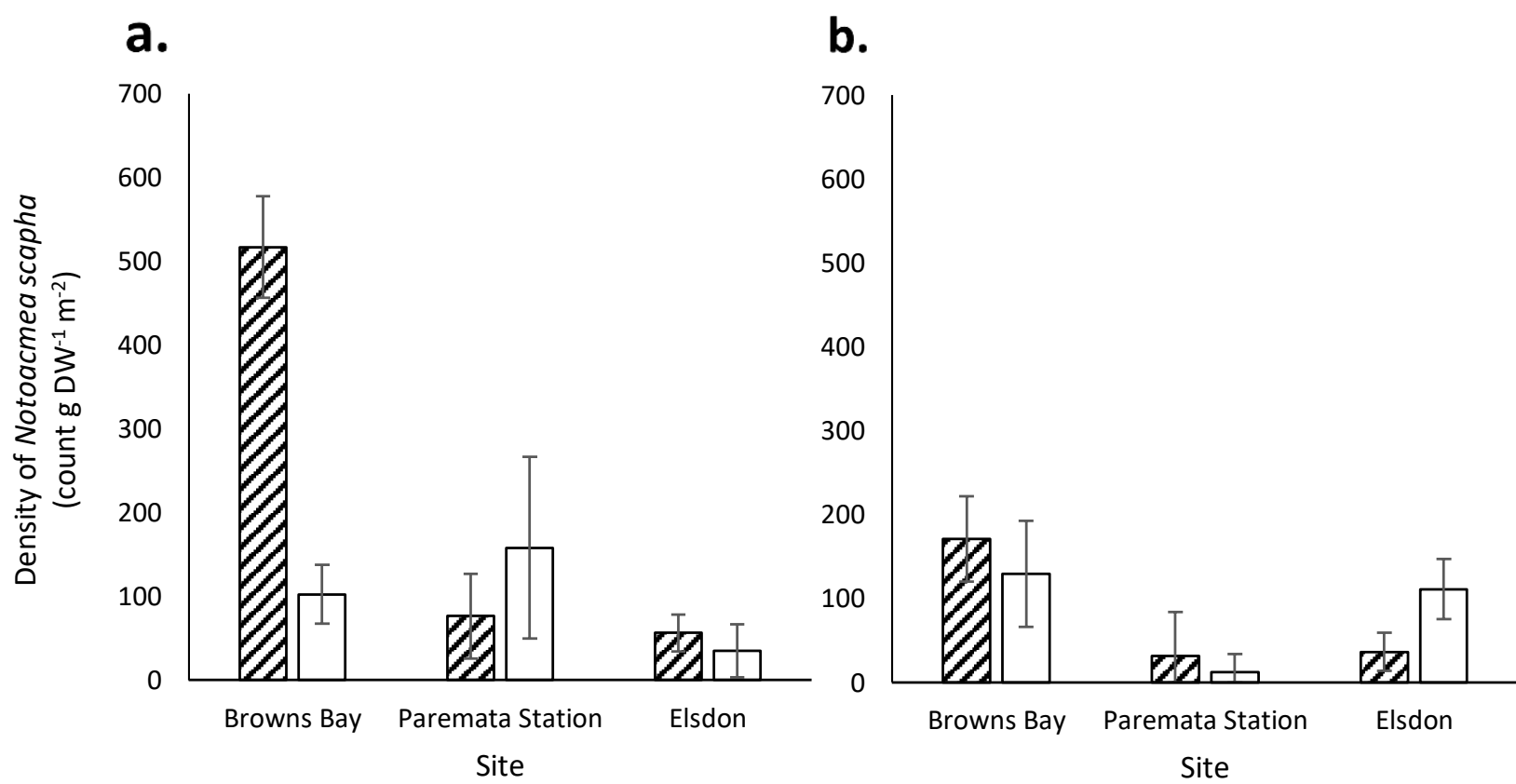

Figure 2.7: Average (+/- $95 \%$ confidence intervals) density of Notoacmea scapha on seagrass from sites in Porirua Harbour in (a) summer and (b) winter. Patterned bars represent upper tidal heights; open bars represent lower. $\mathrm{n}=8$ quadrats per tidal height. 


\section{Diloma spp.}

Significant site and season effects and an interaction between the two were observed for the topshell Diloma spp. densities (Table 2.5 ), which were highly variable even among replicate quadrats. Although there were no effects of tidal height, each site had different seasonal abundance of this species. For example, the greatest average density occurred at Elsdon in summer, with an average of 33.5 individuals $\mathrm{g} \mathrm{DW}^{-1} \mathrm{~m}^{-2}$, but winter densities were extremely low (Figure 2.8). Browns Bay had similar intermediate densities in summer and winter, whereas Diloma spp. were virtually absent at Paremata Station in summer, and completely absent in winter (Figure 2.8). There were few Diloma juveniles in either season, averaging $<3$ individuals $\mathrm{g} \mathrm{DW}^{-1} \mathrm{~m}^{-2}$ in upper Browns Bay during winter.

Table 2.5: Results of PERMANOVA examining effects of season (summer and winter) and site (Browns Bay, Paremata Station and Elsdon) and tidal height (upper and lower) on density of Diloma spp. ( $\left.\mathrm{g} \mathrm{DW}^{-1} \mathrm{~m}^{-2}\right)$ in the Porirua Harbour.

\begin{tabular}{|l|l|l|l|l|}
\hline Source of Variation & df & Resid. SS & Iterations & $\operatorname{Pr(Prob)~}$ \\
\hline Season & 1 & 3697 & 5000 & 0.0044 \\
\hline Site & 2 & 3662 & 5000 & 0.0048 \\
\hline Tidal height & 1 & 5 & 51 & 1.0 \\
\hline Season*Site & 2 & 3708 & 5000 & 0.0066 \\
\hline Season*Tidal height & 1 & 477 & 155 & 0.3935 \\
\hline Site*Tidal height & 2 & 465 & 303 & 0.3003 \\
\hline Season*Site*Tidal height & 2 & 1247 & 847 & 0.1842 \\
\hline Residuals & 84 & 34818 & & \\
\hline
\end{tabular}




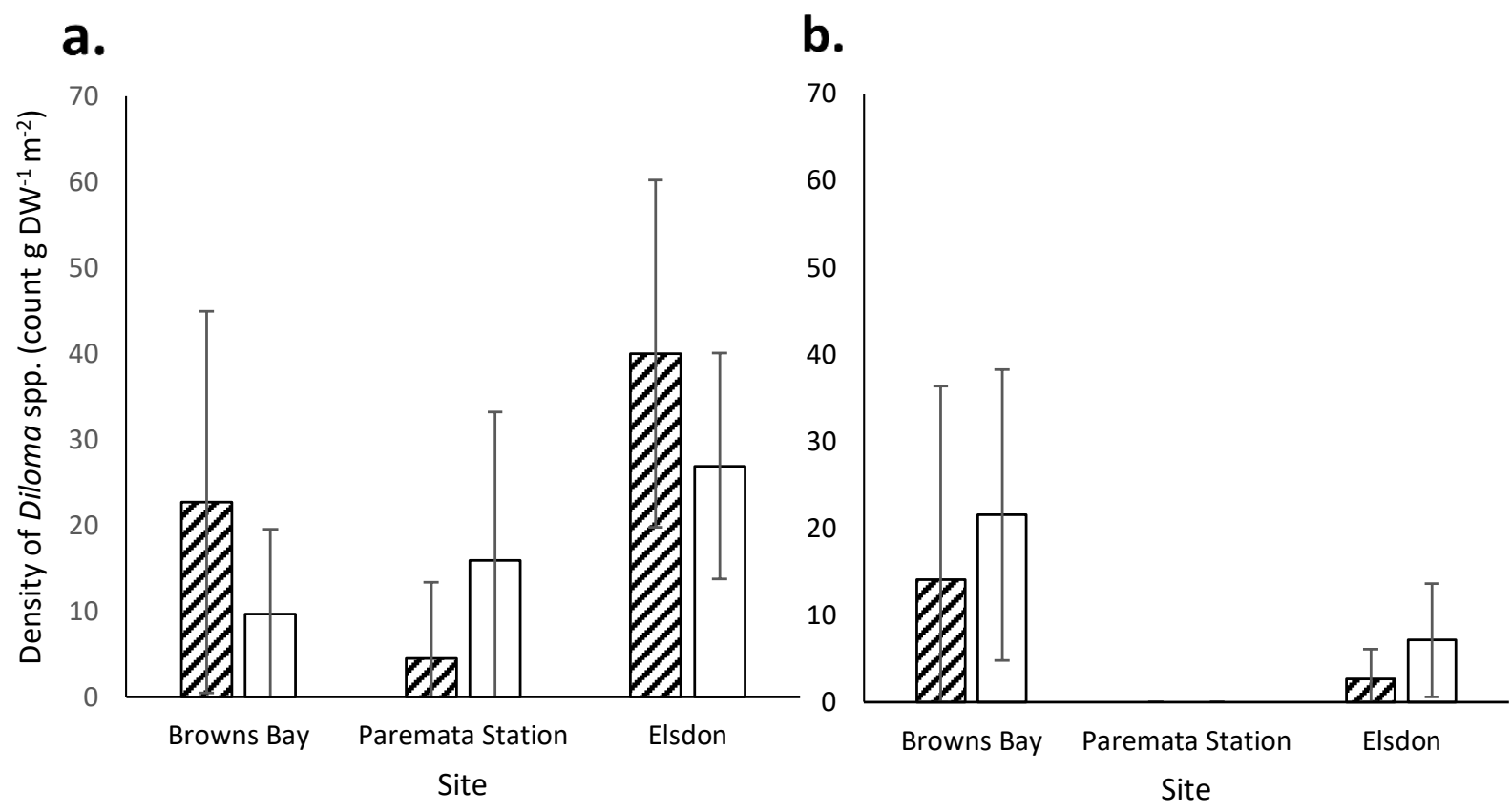

Figure 2.8: Average (+/- $95 \%$ confidence intervals) density of Diloma spp. on seagrass from sites in Porirua Harbour in (a) summer and (b) winter. Patterned bars represent upper tidal heights; open bars represent lower. $\mathrm{n}=8$ quadrats per tidal height.

The individual Diloma species also showed interesting trends. Densities of Diloma subrostrata differed between sites and seasons (Table 2.6). Pooled across seasons, Browns Bay had 3 to 6 times greater densities than Elsdon or Paremata Station, respectively (Figure 2.9). Summer densities were 5 times higher than those of winter, when pooled across sites (Figure 2.9). Diloma arida densities were influenced by site and the interaction of site and season (Table 2.7). Once again, Browns Bay contained the greatest density, though this time in winter, peaking at an average of 15 individuals $\mathrm{g} \mathrm{DW}^{-1} \mathrm{~m}^{-2}$ (Figure 2.9). Densities at Browns Bay increased between summer and winter, while those at Paremata Station and Elsdon decreased over the same period (Figure 2.9). Diloma zelandica densities were influenced by season, site and the interaction of the two (Table 2.8). D. zelandica were absent in winter across all three sites. Average density peaked at 20 individuals $\mathrm{g} \mathrm{DW}^{-1} \mathrm{~m}^{-2}$ at Elsdon in summer (Figure 2.9). This likely drives the corresponding peak in Diloma spp. densities at this site. Browns Bay and Paremata Station tended to have similar D. zelandica densities (Figure 2.9). 
Table 2.6: Results of PERMANOVA examining effects of season (summer and winter) and site (Browns Bay, Paremata Station and Elsdon) on Diloma subrostrata densities $\left(\mathrm{g} \mathrm{DW}^{-1} \mathrm{~m}^{-2}\right.$ ) in the Porirua Harbour.

\begin{tabular}{|l|l|l|l|l|}
\hline Source of Variation & $\mathrm{df}$ & Res. SS & Iterations & $\operatorname{Pr}(\operatorname{Prob})$ \\
\hline Site & 2 & 1221.5 & 5000 & 0.0018 \\
\hline Season & 1 & 950.7 & 5000 & 0.0082 \\
\hline Site*Season & 2 & 225.9 & 303 & 0.3465 \\
\hline Residuals & 122 & 12687.3 & & \\
\hline
\end{tabular}

Table 2.7: Results of PERMANOVA examining effects of season (summer and winter) and site (Browns Bay, Paremata Station and Elsdon) on Diloma arida densities $\left(\mathrm{g} \mathrm{DW}^{-1} \mathrm{~m}^{-2}\right.$ ) in the Porirua Harbour.

\begin{tabular}{|l|l|l|l|l|}
\hline Source of Variation & $\mathrm{df}$ & Res. SS & Iterations & $\operatorname{Pr}(\operatorname{Prob})$ \\
\hline Site & 2 & 2114.6 & 5000 & 0.0008 \\
\hline Season & 1 & 2.7 & 51 & 0.9804 \\
\hline Site*Season & 2 & 1325.6 & 5000 & 0.0092 \\
\hline Residuals & 122 & 19708.4 & & \\
\hline
\end{tabular}

Table 2.8: Results of PERMANOVA examining effects of season (summer and winter) and site (Browns Bay, Paremata Station and Elsdon) on Diloma zelandica densities $\left(\mathrm{g} \mathrm{DW}^{-1} \mathrm{~m}^{-2}\right)$ in the Porirua Harbour.

\begin{tabular}{|l|l|l|l|l|}
\hline Source of Variation & df & Res. SS & Iterations & $\operatorname{Pr}$ (Prob) \\
\hline Site & 2 & 1538.3 & 5000 & 0.0020 \\
\hline Season & 1 & 1803.3 & 5000 & $<0.0001$ \\
\hline Site*Season & 2 & 1538.3 & 5000 & 0.0040 \\
\hline Residuals & 122 & 15058.0 & & \\
\hline
\end{tabular}
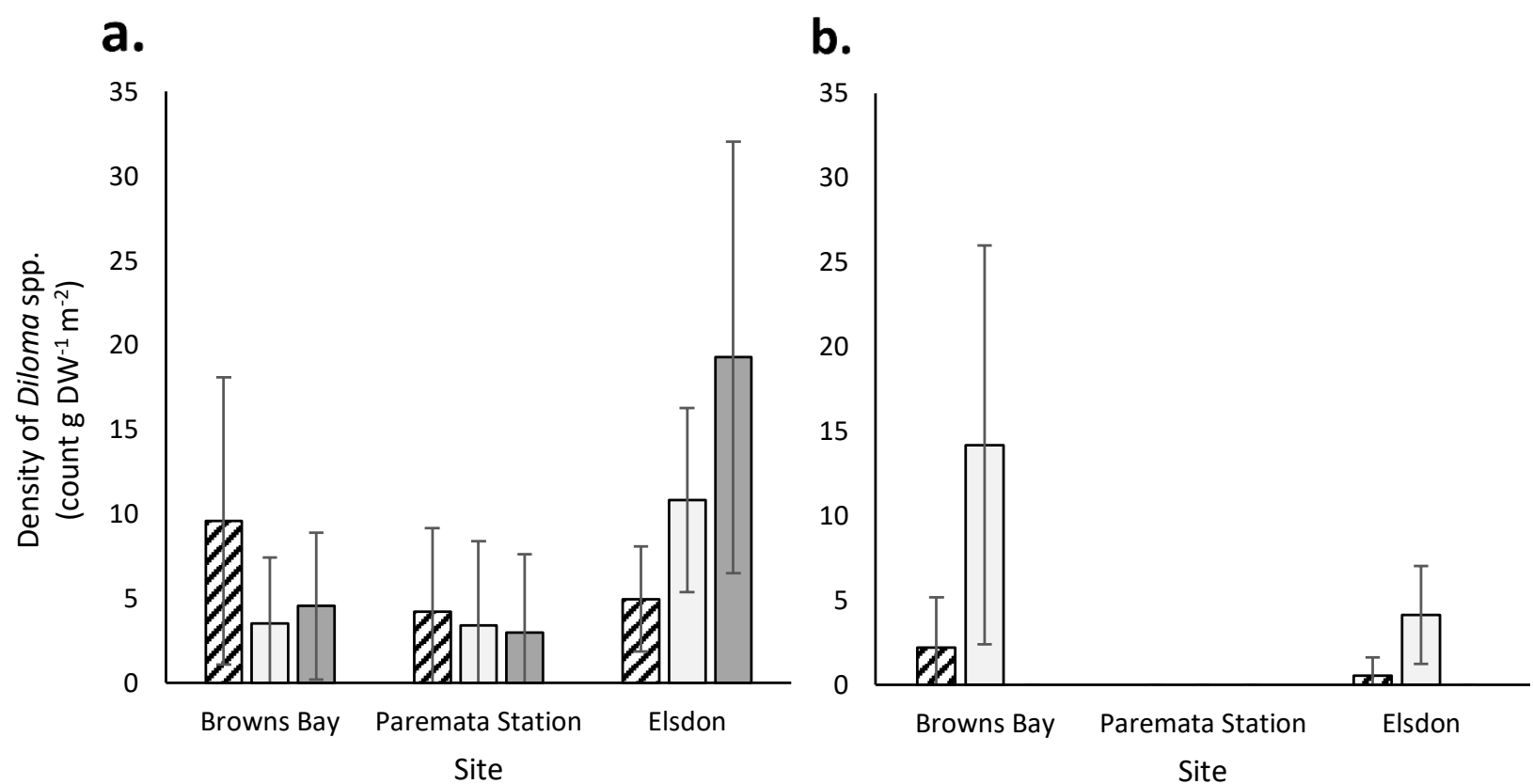

Figure 2.9: Average (+/- $95 \%$ confidence interval) density of Diloma spp. associated with seagrass in Porirua Harbour in (a) summer and (b) winter, with data pooled across tidal height. Patterned bars represent $D$. subrostrata; opened bars $D$. arida; grey bars represent $D$. zelandica. $\mathrm{n}=16$ quadrats per site. 


\section{Micrelenchus spp.}

Densities of another topshell, in the genus Micrelenchus spp., showed less variability than the other micro-gastropods, and were influenced by site and tidal height only (Table 2.9).

Average densities were greatest at Browns Bay, about double that of Paremata Station and Elsdon, and they were also greater at the lower tidal height (Figure 2.10). Juvenile

Micrelenchus were consistently high across both summer and winter, with densities at least 2 times greater than adults at lower and upper Browns Bay (summer and winter respectively).

Table 2.9: Results of PERMANOVA examining effects of season (summer and winter) and site (Browns Bay, Paremata Station and Elsdon) and tidal height (upper and lower) on density of Micrelenchus spp. $\left(\mathrm{g} \mathrm{DW}^{-1} \mathrm{~m}^{-2}\right)$ in the Porirua Harbour.

\begin{tabular}{|l|l|l|l|l|}
\hline Source of Variation & df & Resid. SS & Iterations & Pr(Prob) \\
\hline Season & 1 & 6 & 51 & 0.9608 \\
\hline Site & 2 & 5245 & 5000 & 0.0096 \\
\hline Tidal height & 1 & 2048 & 2040 & 0.0471 \\
\hline Season*Site & 2 & 1514 & 464 & 0.3341 \\
\hline Season*Tidal height & 1 & 576 & 510 & 0.1647 \\
\hline Site*Tidal height & 2 & 2030 & 334 & 0.2305 \\
\hline Season*Site*Tidal height & 2 & 264 & 68 & 0.8235 \\
\hline Residuals & 84 & 51887 & & \\
\hline
\end{tabular}
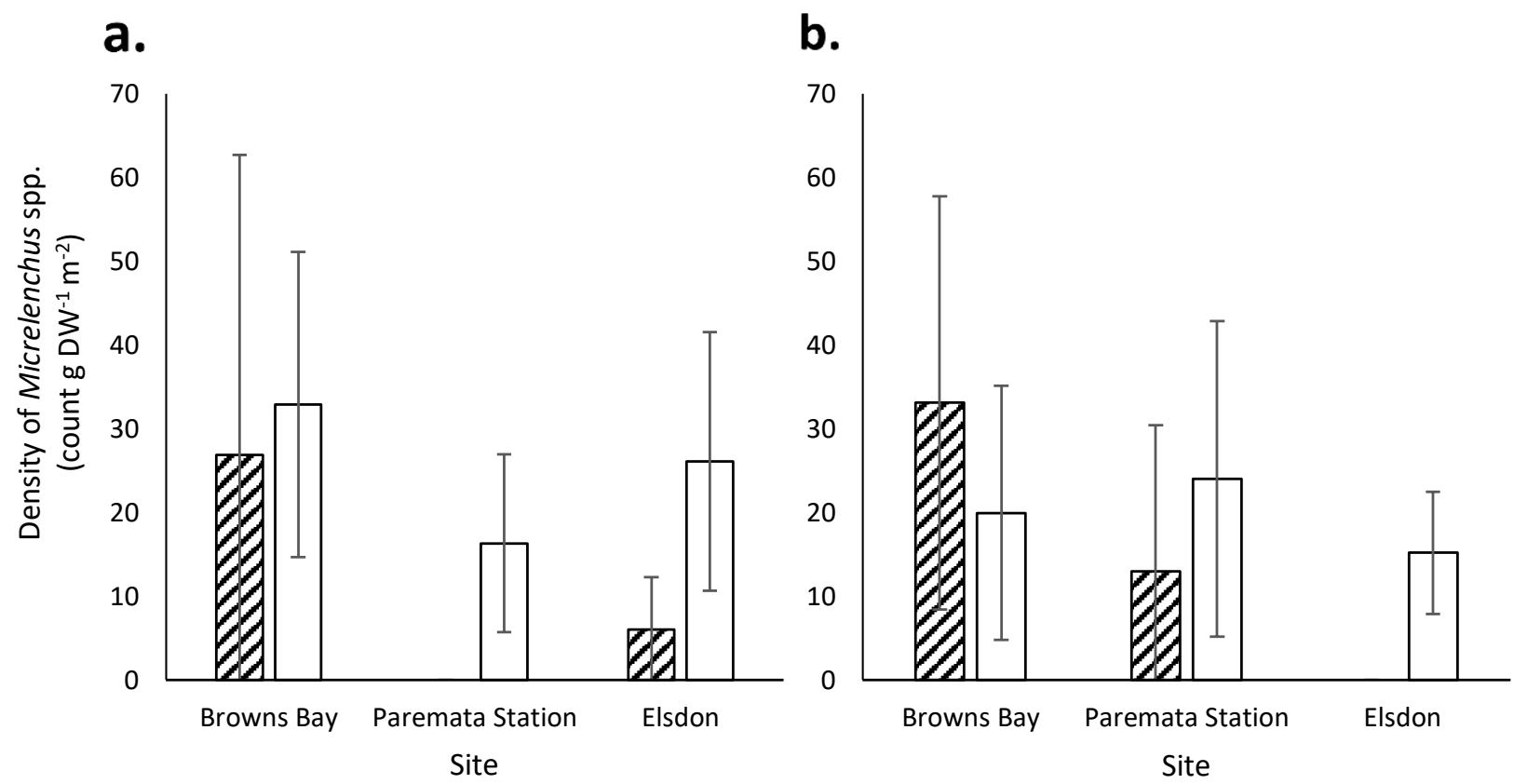

Figure 2.10: Average (+/- 95\% confidence intervals) total density of Micrelenchus spp. associated with seagrass from sites in Porirua Harbour in (a) summer and (b) winter. Patterned bars represent upper tidal heights; open bars represent lower. $n=8$ quadrats per tidal height 


\section{Total Gastropods (all trophic levels)}

Total gastropod density varied by tidal height, site and season, and the interactions of season and tidal height, site and tidal height, and season, site and tidal height (Table 2.10).

Densities were more similar across tidal heights and sites in winter, compared to summer (Figure 2.11). The upper shores of Browns Bay and Paremata Station in the summer had much higher densities than almost all other tidal heights (Figure 2.11). Densities in the lower shore of all three sites were similar across all three seasons (Figure 2.11).

Table 2.10: Results of PERMANOVA examining effects of season (summer and winter) and site (Browns Bay, Paremata Station and Elsdon) and tidal height (upper and lower) on density of all gastropods $\left(\mathrm{g} \mathrm{DW}^{-1} \mathrm{~m}^{-2}\right)$ in the Porirua Harbour.

\begin{tabular}{|l|l|l|l|l|}
\hline Source of Variation & df & Resid. SS & Iterations & $\operatorname{Pr}$ (Prob) \\
\hline Season & 1 & 476245 & 5000 & $<0.0001$ \\
\hline Site & 2 & 747594 & 5000 & $<0.0001$ \\
\hline Tidal height & 1 & 484018 & 5000 & $<0.0001$ \\
\hline Season*Site & 2 & 190872 & 2238 & 0.1278 \\
\hline Season*Tidal height & 1 & 438689 & 5000 & $<0.0001$ \\
\hline Site*Tidal height & 2 & 847668 & 5000 & $<0.0001$ \\
\hline Season*Site*Tidal height & 2 & 500433 & 5000 & 0.0056 \\
\hline Residuals & 84 & 4308553 & & \\
\hline
\end{tabular}

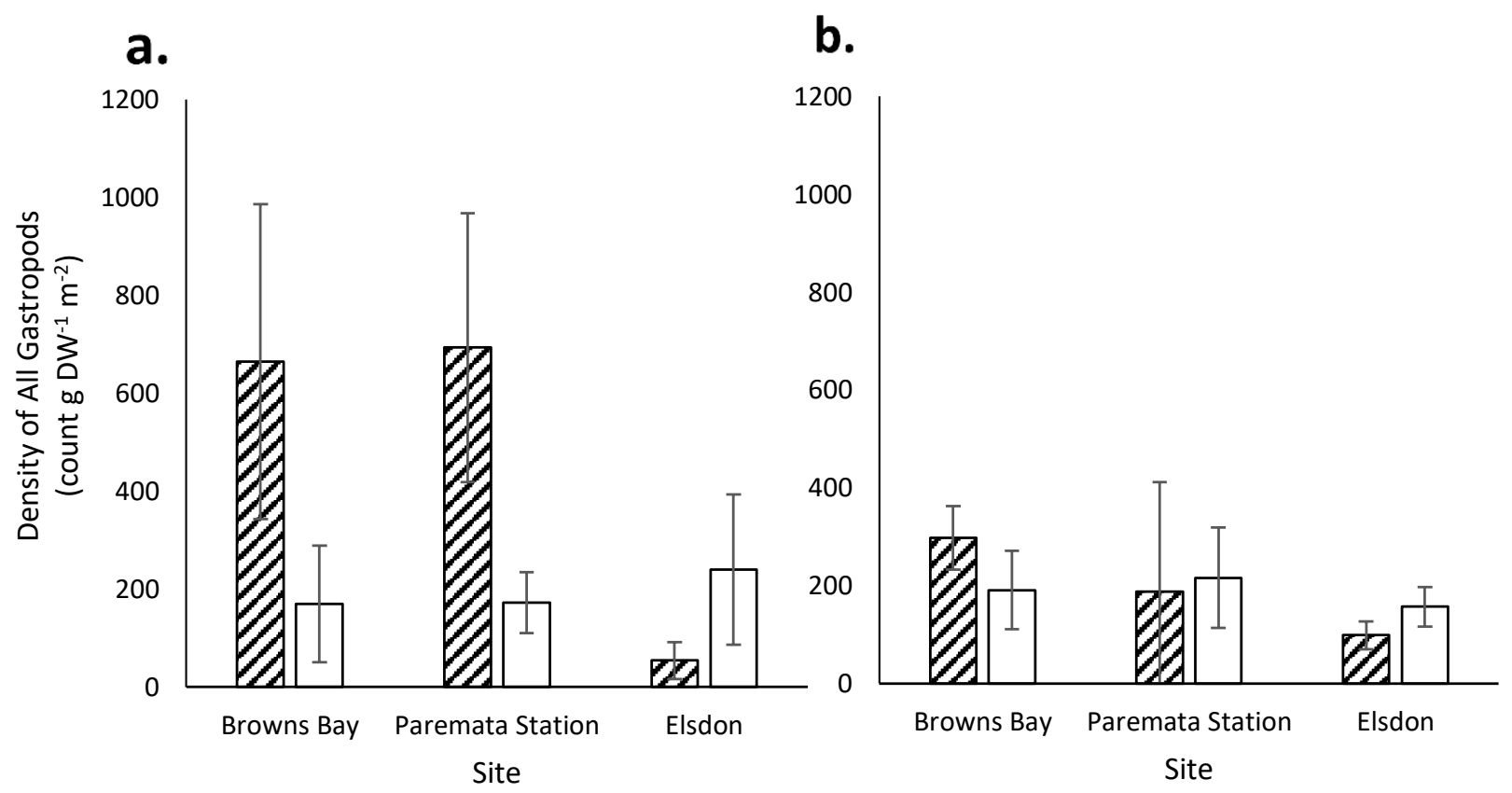

Figure 2.11: Average (+/- $95 \%$ confidence intervals) total density of all gastropods associated with seagrass from sites in Porirua Harbour in (a) summer and (b) winter. Patterned bars represent upper tidal heights; open bars represent lower. $n=8$ quadrats per tidal height 


\section{Other Gastropods}

Total Cominella glandiformis and Zeacumantus lutulentus densities were sufficiently high across sites and seasons that they qualified numerically for statistical examination, however, as predators/scavengers were not directly associated with seagrass blades, they are likely to be misrepresented due to sampling methods, so were not analysed statistically. Overall, $Z$. lutulentus densities were greatest at Paremata Station in summer, and in Browns Bay in winter. These peaks were driven by juvenile density at Paremata Station and adult density at Browns Bay. Elsdon consistently had the lowest Z. lutulentus and C. glandiformis densities.

Cominella spp. egg capsules and C. glandiformis juveniles showed different distributions from adults. Egg capsules were abundant on blades at Browns Bay in summer, and were also present in Elsdon in the same season. However, C. glandiformis adults predominantly occurred at Paremata Station in summer with intermediate densities at Browns Bay and in low densities at Elsdon, where they were absent in winter. Juveniles were found at Elsdon in winter and Browns Bay in winter. Juveniles emerged from egg capsules collected during summer within two weeks of collection, so it is surprising that juveniles were collected in winter. Whelks are not directly associated with seagrass blades, so it is likely that collection methods did not provide an accurate representation of their distribution. 


\section{Discussion}

This study found a high degree of spatial and temporal variation in seagrass characteristics and the associated gastropod assemblage, both within and among the three sampled sites of the Porirua Harbour. As hypothesized, Elsdon had the lowest total gastropod densities, though this was less obvious in winter. Furthermore, epiphyte biomass appeared to exceed grazer control in winter, as hypothesized, though seagrass blades were not as worn in this season as in summer. Seagrass at all sites appear to undergo self-thinning in the winter, as evidenced by a reduction of above-ground biomass. This seasonal biomass change was only slight at Paremata Station and Browns Bay, likely due to the increased blade area associated with winter. However, Elsdon experienced a dramatic decline in biomass when blade area remained constant between seasons. Within each site, the lower shore had greater biomass than upper shore in both seasons. Blade area in the lower shore was greater than upper shore in winter, but similar in summer.

Overall, gastropod densities were highest in summer, with the greatest densities occurring in the upper shore of Paremata Station and Browns Bay (Figure 2.11). Interestingly, Elsdon densities were highest in lower shore and showed little seasonal change. Of the individual taxa examined, the micro-gastropods $N$. scapha and $P$. estuarinus attained much higher densities than the other species, and were also the only species to show large variation in abundance across sites (Browns Bay and Paremata Station, respectively), although these patterns were mostly driven by high densities in summer and at a single tidal height. Densities of Diloma spp., were much lower, and were greatest at Elsdon in summer and did not vary over tidal height. The lack of green blades in summer indicates damage by UV or desiccation. These damaged blades will have been replaced, reducing the presence of epiphytes, as only diatoms would have colonised the blades (Piazzi et al., 2016). These diatoms were likely controlled by the gastropods, further reducing epiphyte presence (Miller and Poulin, 2001; Nakano and Spencer, 2007; Winterbourn and Fegley, 1989). Winter reductions in gastropod densities coincided with increases in epiphyte presence, suggesting release of algae from grazer control. 


\section{Spatial Variation in Seagrass}

Seagrass has the ability to change its physiology in response to ongoing environmental conditions such as light or nutrient availability, turbidity and sedimentation. For example, Korean seagrass inhabiting the lower intertidal is often larger with denser shoots compared to higher tidal heights (Kim et al., 2013). A similar trend is seen in the Porirua Harbour, where the lower tidal height showed greater above-ground biomass in both seasons and larger blade area in winter. Self-thinning and changes in blade area are common responses to reduced light availability (reviewed by Ralph et al., 2007). Reduced solar radiation in winter, coupled with increased algal presence, is the most likely cause of light limitation in the Porirua Harbour in winter (Bulmer et al., 2016; Matheson and Wadha, 2012; Moore and Wetzel, 2000). While summer is recognised as the 'growth season' world-wide (Clausen et al., 2014; Turner and Schwarz, 2006; Wong et al., 2013), the benign climate in New Zealand's North Island may extend the growing season through winter (Turner and Schwarz, 2006).

Desiccation stresses can be reduced by sediment grain size, due to increased water retention by smaller grains. Grain size can therefore influence seagrass morphology more than shore position (Azevedo et al., 2016). Ongoing monitoring of sediment size in the Porirua Harbour indicates that of the three study sites, Elsdon has the highest mud (i.e. small grain-size) content (9.4\% mud) (Stevens and Robertson, 2016). However, Elsdon is also a very short site $(<70 \mathrm{~m})$, so increased water retention by sediments is unlikely to play a large role, since tidal exposure is shorter than other sites. Grain size is also a factor influencing the severity of turbidity in an area, with smaller grains becoming more easily suspended in the water column. Seagrass responds to ongoing turbidity and blade abrasion by reducing shoot density and blade size (Miller et al., 2005).

\section{New Zealand Meadows}

A survey of Coromandel Peninsula seagrass found that sites with the longest tidal exposure (i.e. where low tide lasted longest) produced the lowest above-ground biomass (Turner and Schwarz, 2006) This same trend can be seen at Paremata Station in both seasons, but is especially prominent during winter self-thinning. Paremata Station is the largest of the three sites $(>160 \mathrm{~m})$, with seagrass in the upper shore exposed for much longer than that of Browns Bay $(<110 \mathrm{~m})$ or Elsdon $(<70 \mathrm{~m})$. Sampling at Browns Bay and Elsdon was time 
pressured by the returning tide, where Paremata Station was not. Surveys of upper North Island harbours revealed average above-ground biomass ranging from 13 to $170 \mathrm{~g}^{-1} \mathrm{DW} \mathrm{m}^{-2}$ (Matheson and Schwarz, 2007). The average biomass measured in this study, 7-49 g DW-1 $\mathrm{m}^{-2}$, is lower than the northern estimation, as well as previous biomass estimates at the same sites (Table 2.11; Duncan, 2015). The present study is the third to investigate seagrass in the Porirua Harbour since 2012, all of which suggest southern seagrass meadows may be naturally less dense than northern meadows. Biomass and blade size in the Porirua Harbour were relatively low in the winter of 2012 (Table 2.11; Matheson and Wadha, 2012) compared to the summer of 2015 (Table 2.11; Duncan, 2015), except for Ivey Bay which decreased in blade area and above-ground biomass between studies. In the present study, the greatest above-ground biomass occurred in summer at Elsdon. Elsdon was not surveyed by Matheson and Wadha (2012) as it was deemed to have too little seagrass for collection, suggesting that this site has expanded between 2011 and 2016. In the present study, average blade lengths were similar to those reported for northern harbours (Turner and Schwarz, 2006), but blade width was more variable. Blade length and width was greater in this study than in previous Porirua Harbour studies (Table 2.11). 
Table 2.11: Summary of selected previous studies on seagrass above-ground biomass, blade width and blade length around New Zealand. Turner and Schwarz (2006) investigated 4 sites over 2 seasons, but presented average data in a graph, making estimation of values difficult. Data is presented as averages with standard error in brackets, except for data from Turner and Schwarz (2006) and Matheson and Schwarz (2007) as the data presented is the range of averages across sites/seasons (Turner and Schwarz) and sub-sites (Matheson and Schwarz). Matheson and Schwarz (2007) did not investigate blade morphometrics. * Elsdon Two in Duncan (2015) is the same site as Elsdon in the present study.

\begin{tabular}{|c|c|c|c|c|}
\hline Authors & Site & $\begin{array}{l}\text { Above-Ground Biomass } \\
\mathrm{g} \mathrm{DW}^{-1} \mathrm{~m}^{-2}\end{array}$ & $\begin{array}{l}\text { Blade Width } \\
\text { mm }\end{array}$ & $\begin{array}{l}\text { Blade Length } \\
\mathrm{mm}\end{array}$ \\
\hline Turner and Schwarz (2006) & Coromandel Peninsula (4 sites) & $46-81$ & $1.1-1.8$ & $55-90$ \\
\hline \multirow{3}{*}{ Matheson and Schwarz (2007) } & Raglan Harbour & $15-85$ & $\mathrm{n} / \mathrm{a}$ & $\mathrm{n} / \mathrm{a}$ \\
\hline & Tauranga Harbour & $13-84$ & $\mathrm{n} / \mathrm{a}$ & $\mathrm{n} / \mathrm{a}$ \\
\hline & Whangapoua Harbour & $60-170$ & $\mathrm{n} / \mathrm{a}$ & $\mathrm{n} / \mathrm{a}$ \\
\hline \multirow{3}{*}{ Matheson and Wadha (2012) } & Bradeys Bay, Porirua & $7(3)$ & $1.7(0.2)$ & $46(14)$ \\
\hline & Ivey Bay, Porirua & $60(26)$ & $2.1(0.0)$ & $66(3)$ \\
\hline & Paremata Station, Porirua & $6(2)$ & $0.9(0.1)$ & $45(3)$ \\
\hline \multirow{7}{*}{ Duncan (2015) } & Bradeys Bay, Porirua & $36(40)$ & $1.7(0.4)$ & $59(24)$ \\
\hline & Browns Bay, Porirua & $17(11)$ & $1.5(0.3)$ & $54(23)$ \\
\hline & Ivey Bay, Porirua & $50(18)$ & $1.4(0.3)$ & $42(22)$ \\
\hline & Mana, Porirua & $40(20)$ & $1.5(0.4)$ & $60(28)$ \\
\hline & Paremata Station, Porirua & $18(16)$ & $0.8(0.4)$ & $35(18)$ \\
\hline & Elsdon One, Porirua & $35(17)$ & $1.7(0.5)$ & $66(27)$ \\
\hline & Elsdon Two*, Porirua & $53(30)$ & $1.7(0.4)$ & $62(29)$ \\
\hline \multirow{3}{*}{ Present Study } & $\begin{array}{c}\text { Browns Bay, Summer: } \\
\text { Winter }\end{array}$ & $\begin{array}{l}12(5) \\
13(5)\end{array}$ & $\begin{array}{l}1.9(0.4) \\
2.1(0.4)\end{array}$ & $\begin{array}{l}71(15) \\
80(22)\end{array}$ \\
\hline & $\begin{array}{c}\text { Paremata Station, Summer: } \\
\text { Winter }\end{array}$ & $\begin{array}{l}10(5) \\
7(5)\end{array}$ & $\begin{array}{l}1.0(0.1) \\
1.0(0.2)\end{array}$ & $\begin{array}{l}57(13) \\
66(19)\end{array}$ \\
\hline & $\begin{array}{l}\text { Elsdon, Summer: } \\
\text { Winter }\end{array}$ & $\begin{array}{l}49(20) \\
26(9)\end{array}$ & $\begin{array}{l}2.2(0.3) \\
2.2(0.4)\end{array}$ & $\begin{array}{l}81(21) \\
85(27)\end{array}$ \\
\hline
\end{tabular}

$\dot{f}$ 


\section{Spatial Variation in Gastropods}

The topography of seagrass meadows within the Porirua Harbour appears relatively homogenous, so it is surprising to find such differences in the dominant gastropod species at sites less than 4 kilometres apart. While the gastropods are small ( $P$. estuarinus and $N$. scapha $<7 \mathrm{~mm}$, Diloma spp. and Micrelenchus spp. approx. $1.5 \mathrm{~cm}$ ), they are also mobile. For example, Hydrobidae (the family of Hydrobia and Potamopyrgus) drift via mucous nets or air bubbles at the shell opening, or crawling along the sediment (reviewed by Cardoso et al., 2002; Sola, 1996) at up to $40 \mathrm{~cm}$ per hour while submerged (Orvain and Sauriau, 2002). It seems likely, therefore, that $P$. estuarinus in the present study migrate between and within seagrass meadows. There has been little research into the movement of gastropods on soft shores outside of Hydrobia spp. Interestingly, where movement of rocky shore gastropods is influenced by habitat complexity, soft-shore gastropods are not (Bishop et al., 2007; Crowe, 1996). Either way, it appears that the ability to drift is the most likely method for moving between sites, but within-site movement is achievable by crawling.

There is also little available information on the tolerance of grazers to abiotic variables other than epiphyte and seagrass metrics (e.g. Gartner et al., 2010; Nelson and Waaland, 1997). As in the present study, Blanchet et al. (2004) found high variation between communities within French Z. noltii beds, with highly variable community richness, species/phylum dominance, and invertebrate biomass. Hydrobia ulvae was almost always the dominant gastropod, with average densities of 7,404 to 14,377 individuals $\mathrm{m}^{-2}$, exceeding all gastropod densities in the Porirua Harbour, including the similar P. estuarinus. They concluded that variation in salinity and tidal exposure where major structuring influences on community composition. H. ulvae in the Mondego Estuary (Portugal), have four recruitment events per year in spring, autumn and summer (Cardoso et al., 2002; Lillebo et al., 1999). Water temperature appears to influence the life span in this species. Summer recruits had the shortest life spans (16 month) (Cardoso et al., 2002), and H. ulvae in the colder Dovey Estuary (Wales) are recorded to live for up to 30 months (Fish and Fish, 1974). The seasonal differences in grazer densities of the Porirua Harbour may be driven by cohort recruitment success, as was recorded in a saltmarsh for the periwinkle Littoraria irrorata (Schindler et al., 1994). On this note, while 'seasonal differences' are discussed here, this study only 
surveyed two seasons within a single year. To obtain an accurate estimate of seasonal trends, surveys over multiple years would be required.

The inclusion of gastropods in seagrass surveys is uncommon, making comparisons of Porirua results difficult, especially due to the endemic status of the dominant grazers. A survey conducted in a Z. noltii meadow in Southern Portugal identified the dominant gastropod as a grazer (Bittium reticulatum), with an average density 7 times that of the second most dominant gastropod (the micro-snail Rissoa membranacea) (Almeida et al., 2008). In a similar study, Hydrobia ulvae occurred in high densities and accounted for $>75 \%$ of total yearly secondary production in a mixed Zostera meadow (Dolbeth et al., 2003). Their dominance was suggested to be caused by high reproductive output, due to the high food availability and beneficial physical variables (e.g. temperatures, microhabitats) of the estuary. This appears to also be the case for $P$. estuarinus in the lower tidal height of Paremata Station in summer, where less variation in salinity during low tide and beneficial abiotic factors appear to be at play. However, its preference for Paremata Station over the fresh-water influenced Elsdon is surprising, since $P$. estuarinus prefers lower salinities.

Macroalgae (mostly Ulva spp. and Gracilaria spp.) were observed to grow amongst seagrass shoots at all sites in both summer and winter, an occurrence known to boost grazer densities overseas (Whalen et al., 2013). This macroalgal presence may explain how Micrelenchus spp. and Diloma spp. could both occur at fairly high densities across sites and seasons. The apparent partitioning of the three Diloma species between the three sites is also interesting, though reasons for the preferences are not clear. D. subrostrata in Company Bay (Otago, New Zealand) were recorded 50m from the low tide mark (Miller and Poulin, 2001). This distance falls between tidal heights at Paremata Station and Browns Bay, and at the upper tidal height for Elsdon. The Otago densities were only reached in Porirua when all Diloma species and tidal heights were pooled in summer at Elsdon, suggesting that the $50 \mathrm{~m}$ peak either occurred at a different tidal height in this estuary, or wasn't sampled. Distributions of Micrelenchus spp. and Diloma spp. were very patchy, possibly due to their movement patterns in response to tidal inundation, or abiotic influences. Diloma especially has been observed to migrate to small puddles, or under empty cockle shells when the tide recedes (Leigh Stevens pers. comm.). 
While rocky shore gastropods exhibit distinct 'vertical zonation' driven by adaptations to desiccation and predator avoidance (reviewed by Connell, 1972; Fawcett, 1984; McMahon, 1990), the importance of desiccation within seagrass meadows is unclear. For example, seagrass blades lay flat during low tide, trapping water beneath them, and may therefore provide an escape from desiccation, as observed with mangrove litter (Tavares et al., 2015). In the present study, gastropod densities varied between tidal heights within the Porirua Harbour, but there was no evidence of vertical zonation.

N. scapha is restricted to protected estuaries, and is found predominantly on Z. muelleri, but also on living $D$. subrostrata (Nakano and Spencer, 2007). The predominance of $D$. subrostrata at Browns Bay in summer may help to explain the peak in N. scapha at this site and season. In an almost opposing trend to $P$. estuarinus, $N$. scapha densities may be negatively influenced by the large, dense blades of Elsdon. A probable further reason for their differing distributions is direct competition between the two gastropods, as they both prefer to consume epiphytic algae (Nakano and Spencer, 2007; Winterbourn and Fegley, 1989).

\section{Temporal Variation}

When comparing seasonal trends in total gastropod density to epiphyte presence, the ongoing debate of top-down versus bottom-up control in seagrass systems is unavoidable. Top-down control in seagrass systems relates to the ability of grazers to control epiphyte loads, while bottom-up control occurs when epiphytes outcompete seagrass, usually due to eutrophication. Most studies support top-down control of epiphytic algae (e.g. Heck and Valentine, 2007; Jorgensen et al., 2007; Ruesink, 2016). However, as demonstrated by Whalen et al. (2013), top-down and bottom-up influences are spatially and temporally variable. Therefore, single surveys (effectively 'snap-shots' of an environment) and short term experiments are unlikely to capture the shift from a greater influence of one factor to another (Cabaço et al., 2013). Long-term, frequent surveys would be required to elucidate this. The decline in gastropod grazer densities during winter in the present study likely contributes to the increased epiphyte presence, though no single factor alone will be responsible (Edgar, 1990). Increased rainfall in winter will likely increase nutrient levels, which may increase seagrass growth by removing nutrient limitations (Irlandi et al., 2004) or may give epiphytes a competitive advantage (Hughes et al., 2004). While seasonal 
predation has not been investigated in the present study, predation by fish has been linked to reductions in crustacean and gastropod grazers (e.g. Cardoso et al., 2002; Carr and Boyer, 2014). This study is one of the first to directly study the importance of micro-grazers, such as Potamopyrgus or Notoacmea, which are more closely associated with seagrass blades than the more commonly studied crustaceans. 


\section{Effects of Nutrient Addition and Gastropod Grazers on Seagrass from Different Sites.}

\section{Abstract}

In New Zealand, seagrass meadows in the two arms of the Porirua Harbour experience different levels of eutrophication. The industrial area (Elsdon, Onepoto Arm) has high nutrient levels, where Browns Bay (Pauatahanui Arm) is relatively pristine. This study aimed to test the simultaneous effects of elevated nutrients and gastropod grazers on growth and epiphyte loads of seagrass obtained from these two different sites.

A factorial laboratory experiment was conducted with seagrass from Browns Bay (in autumn), and Elsdon (in early winter) where the factors were elevated nutrients (2 levels plus a control) and gastropods (present or absent). Nutrient levels in the two elevated treatments were a High level, similar to those of Elsdon (143 $\mathrm{mg} \mathrm{m}^{-3} \mathrm{NO}_{3}-\mathrm{N}$ and $9 \mathrm{mg} \mathrm{m}^{-3}$ dissolved reactive phosphate (DRP)), and a High+ treatment testing the effects of a $20 \%$ increase. Grazers in the Gastropod Present treatment included 1 Diloma arida and 3 each of Potamopyrgus estuarinus and Notoacmea scapha. The blade growth, new blade production, epiphyte biomass, and $\Delta$ shoot density were measured after three weeks in experimental conditions.

Browns Bay and Elsdon seagrass responded differently, and inconsistently, to nutrient addition and gastropod presence. The only significant effect of grazers occurred in seagrass from Elsdon, where blade production was higher in the presence of gastropods. Overall, Elsdon seagrass was unaffected by nutrient addition. In the Browns Bay trial, however, blade growth was affected by nutrient treatments, and new blade production by the interaction of nutrient and gastropod treatments. The number of blades per container was positively correlated with average blade production and average blade growth in the Browns Bay trial, and with epiphyte biomass in the Elsdon trial. These site-specific responses suggest that seagrass meadows within a harbour can adapt to highly localised abiotic stressors, and that management and monitoring efforts should incorporate sitespecific factors, rather than at the broader harbour scale. 


\section{Introduction}

For many years it was thought that epiphyte growth in seagrass meadows was driven by nutrient availability (i.e. by 'bottom-up' forces), where increased water column nutrient availability allowed increased epiphyte growth rates and biomass, thereby smothering seagrass (see review by Valentine and Duffy, 2007). However, studies conducted during this time did not manipulate or include grazers (see review by Heck and Valentine, 2007). A paradigm shift occurred (and is arguably ongoing) within seagrass ecology once researchers began including grazer effects in field and mesocosm experiments (Heck and Valentine, 2006). Top-down and bottom-up processes are now generally recognised as similarly important, though a lot of recent research has found that top-down control (removal of epiphytes by grazers) is the stronger force in many systems (Christianen et al., 2012; Duffy et al., 2015; Heck and Valentine, 2007; Jorgensen et al., 2007), though this can be temporally variable (Whalen et al., 2013). This may be due to a combination of the surprisingly low light levels that seagrass can tolerate (Abal et al., 1994; Ebrahim et al., 2014) and that seagrass can access nutrients in sediment pore water, or carbohydrates stored in rhizomes, which epiphytes cannot (Burkholder et al., 2007; Ott, 1980).

Increasing coastal urbanisation and use of fertilisers has led to world-wide issues with eutrophication in coastal systems (reviewed by Duarte, 2002; reviewed by Heck and Valentine, 2007). In seagrass systems, this can reduce the strength of top-down effects, leading to an increase in epiphytic, macrophytic, and/or microalgae in the water column, which can smother seagrass and alter system functioning (Burkholder et al., 2007; Hauxwell et al., 2001; Smyth et al., 2013). Zostera species are adapted to low-nutrient conditions, storing nitrates during the day (like all seagrasses) and night (Alexandre et al., 2016; Rubio et al., 2007). Lengthened exposure to high nutrient concentrations can therefore cause carbon limitation (due to the increased rates of carbon uptake through photosynthesis during the day) or ammonium toxicity (Armitage et al., 2005; Burkholder et al., 2007; van Katwijk et al., 1997). For example, Z. noltii growing $270 \mathrm{~m}$ from a sewerage treatment discharge pipe in Southern Portugal showed symptoms of toxicity, with much lower biomass and leaf or internode lengths than meadows further from the pipe (Cabaço et al., 2008). Eutrophication also indirectly reduces grazer richness and density, via habitat loss (less seagrass or increased presence of less palatable algae) and oxygen depletion by increased 
bacterial biomass (Burkholder et al., 2007; Daudi et al., 2012; Gartner et al., 2010), thereby further reducing epiphyte control, and affecting the energy dynamics of the wider system.

Abiotic factors such as temperature and salinity alter the magnitude of eutrophication effects on seagrass (Blake and Duffy, 2012; reviewed by Burkholder et al., 2007; van Katwijk et al., 1997). However, few studies specifically test the effect of grazers under multiple conditions. Two examples of such are Blake and Duffy 2010 and 2012. Functional redundancy in crustacean grazers increased resilience of the simulated system to fresh water input and higher temperatures (Blake and Duffy, 2010), and to increased eutrophication and temperature (Blake and Duffy, 2012). Other studies have also demonstrated the importance of multiple grazer species in maintaining stability (Duffy et al., 2003; Duffy et al., 2015; Tagliapietra et al., 2016), including one examining two gastropods (Jujubinus striatus and Bittium reticulatum) (Gacia et al., 2009). Little research has been conducted in New Zealand to determine the importance and roles of crustacean or gastropod grazers, despite several of New Zealand's important estuaries containing seagrass.

In central New Zealand, seagrass in the Porirua Harbour has ongoing issues with macroalgal smothering due to high nutrient inputs (Matheson and Wadha, 2012; Stevens and Robertson, 2013, 2014), but nutrient loads in the Harbour vary across sites. The most enriched site is Elsdon (near the industrial city centre) with monthly averages of $510 \mathrm{mg} \mathrm{m}^{-3}$ total nitrogen and $59 \mathrm{mg} \mathrm{m}^{-3}$ total phosphate (Matheson and Wadha, 2012), levels that are toxic to the congeneric seagrass species Z. marina (Burkholder et al., 1994). Browns Bay represents a less enriched site, with about half the nutrients of Elsdon: approximately 290 $\mathrm{mg} \mathrm{m}^{-3}$ total nitrogen and $26 \mathrm{mg} \mathrm{m}^{-3}$ total phosphate per month. In addition to the nutrient environment, the seagrass and gastropod assemblage also varies across these two sites (see Chapter 2). Nevertheless, although in different arms of the harbour, because these sites are only $4 \mathrm{~km}$ apart, aside from the nutrient and light levels they are likely exposed to similar other abiotic conditions (e.g. weather, water temperature, salinity) (see Matheson and Wadha, 2012). This study aimed to test the simultaneous effects of elevated nutrients and gastropod grazers on seagrass obtained from these two different locations and address the following questions: do epiphytes respond to enhanced nutrients and does this negatively impact seagrass growth? Can grazers control epiphytes and benefit seagrass? Does the role 
of grazers change under elevated nutrient regimes? Is seagrass from a site with consistently elevated nutrients more tolerant of extreme levels than a site with low ambient nutrient levels? 


\section{Methods}

A fully factorial laboratory experiment was used to investigate the effects of nutrient addition and gastropod presence on seagrass growth and epiphyte biomass (Table 3.1). The experiment was run twice; experiments were conducted in autumn with seagrass from Browns Bay and early winter with seagrass from Elsdon. The overall design of the experiment was to create the nutrient addition treatments in $50 \mathrm{~L}$ tanks of seawater (see treatment details below). Each tank was partitioned in halves by a mesh panel; one side would receive gastropods and the other would not. The mesh was small enough to contain the gastropods ( $1 \mathrm{~mm}$ mesh). On each side of the tank a $2 \mathrm{~L}$ container was placed into which seagrass had been transplanted (details below) (Figure 3.1). There were 3 replicate tanks per nutrient treatment, all held in an outdoor seatable.

Table 3.1: The full factorial design to test the effects of nutrient addition and gastropod presence on seagrass growth and epiphyte biomass. Control = ambient low nutrient seawater concentration, High $=143 \mathrm{mg} \mathrm{m}^{-3} \mathrm{NO}_{3}-\mathrm{N}$ and $9 \mathrm{mg} \mathrm{m}^{-3} \mathrm{DRP}$, $\mathrm{High}+=172 \mathrm{mg} \mathrm{m}^{-3} \mathrm{NO}_{3}-\mathrm{N}$ and $11 \mathrm{mg} \mathrm{m}^{-3}$ DRP.

\begin{tabular}{|l|l|l|}
\hline Treatment \# & Nutrient Treatment & Gastropod Treatment \\
\hline 1 & Control & Present \\
\hline 2 & Control & Absent \\
\hline 3 & High & Present \\
\hline 4 & High & Absent \\
\hline 5 & High + & Present \\
\hline 6 & High + & Absent \\
\hline
\end{tabular}




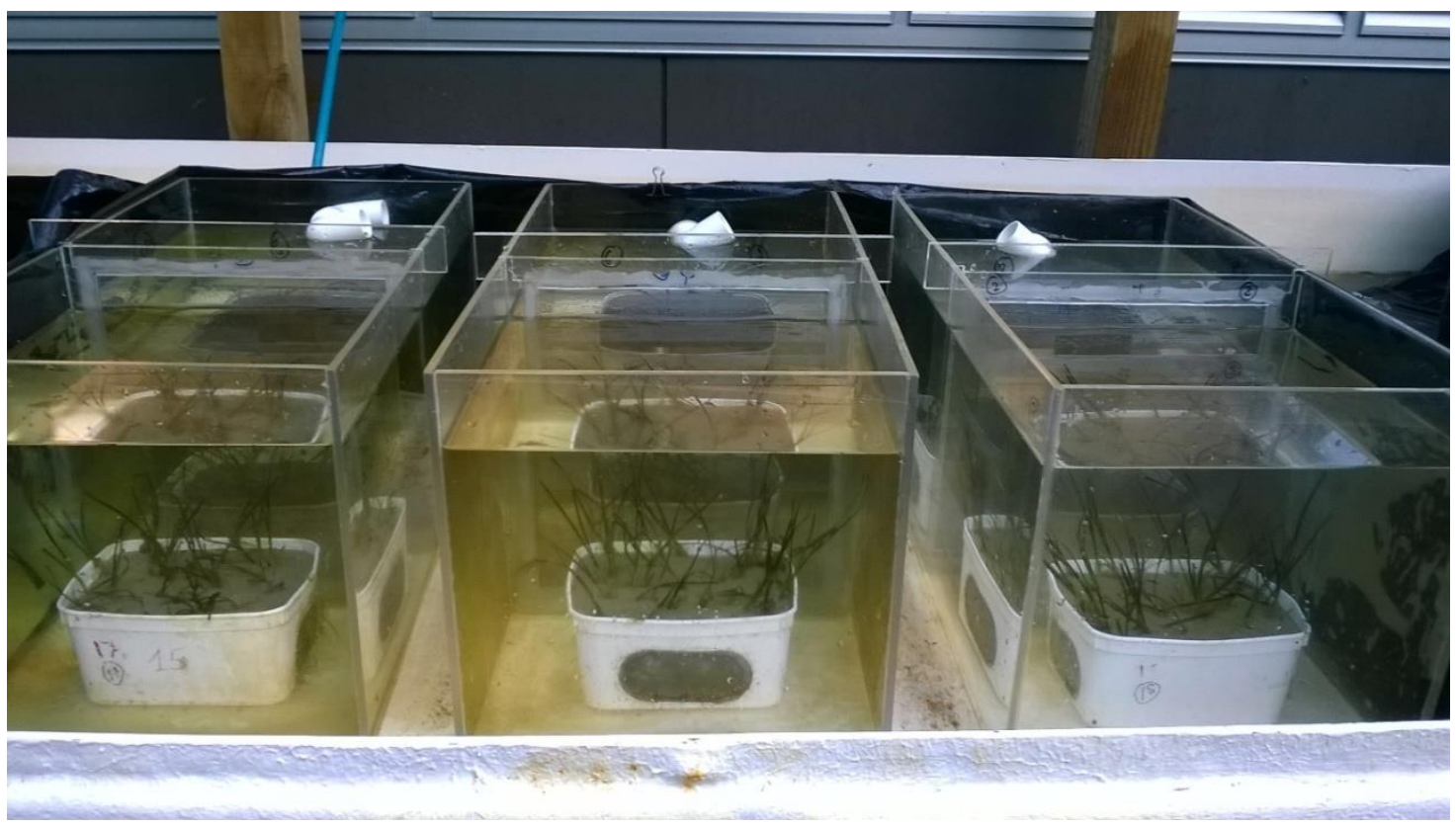

Figure 3.1: Examples of tanks of Browns Bay seagrass. Each tank contains two containers, separated by a divider secured by a brace. Black plastic can be seen wrapped around the sides and back of the tanks. Shade cloth was removed for the photo.

All treatments used as a base filtered, low nutrient seawater $(<6 \mu \mathrm{mol} / \mathrm{L}$ total inorganic nitrate, $<0.4 \mu \mathrm{mol} / \mathrm{L}$ phosphate, (Morelissen, 2012)) from Wellington's South Coast that is available at the Victoria University Coastal Ecology Laboratory (VUCEL). The High treatment nutrient levels were similar to those observed in Elsdon (143 $\mathrm{mg} \mathrm{m}^{-3} \mathrm{NO}_{3}-\mathrm{N}$ and $9 \mathrm{mg} \mathrm{m}^{-3}$ dissolved reactive phosphate (DRP); Matheson and Wadha, 2012). The treatment High+ was intended to test an extreme, but ecologically realistic, level of nutrients, so was $20 \%$ higher than the High treatment ( $172 \mathrm{mg} \mathrm{m}^{-3} \mathrm{NO}_{3}-\mathrm{N}$ and $11 \mathrm{mg} \mathrm{m}^{-3} \mathrm{DRP}$ ). Different amounts of stock solutions of $429.2 \mathrm{mg} \mathrm{L}^{-1} \mathrm{NaNO}_{3}$ and $19.8 \mathrm{mg} \mathrm{L}^{-1} \mathrm{KH}_{2} \mathrm{PO}_{4}$ were added to tanks to achieve the correct final concentrations for High and High+ treatments. The same volume of distilled water $(126 \mathrm{ml})$ was added to Control treatments so that the only difference between control and treatment tanks was the addition of nutrients.

\section{Collection and Acclimation of Seagrass from Low Nutrient Input Site (Browns Bay)}

Seagrass sods and additional sediment were collected from Browns Bay on 10 and 14 March, 2016, and transferred to VUCEL in $10 \mathrm{~L}$ buckets. Seagrass was maintained in the buckets with seawater until planting, 1-2 days after collection. Planting involved filling 18 square, two-litre containers (97x97×80 mm, with two $700 \mu \mathrm{m}$ mesh side panels) with sediment from Browns Bay and another Wellington site, Lyall Bay (in approximately 2:1 
ratio) and adding seagrass. The combination of sediments was selected as a compromise between the characteristics that the seagrass had previously grown in, and sediment uninfluenced by recent nutrient conditions in the Porirua Harbour. Prior to planting, seagrass roots were carefully rinsed of most sediment in a bucket of seawater although some sediment was intentionally retained in roots to prevent root damage. To approximate field densities, 30 to 35 shoots per container were planted using rhizomes with two to five shoots. Each tank (H: $30.5 \mathrm{~cm}, \mathrm{~L}: 60.5 \mathrm{~cm}, \mathrm{~W}: 29.6 \mathrm{~cm})$ had an attached hose delivering filtered seawater to a final volume of $40 \mathrm{~L}$. As the outdoor seatable was in full or partial sunlight for most of the day, tanks were wrapped in black plastic to reduce reflected light from the seatable (Figure 3.2). A shade cloth was used to reduce direct overhead sunlight from above tank and mimic natural conditions of submerged seagrass.

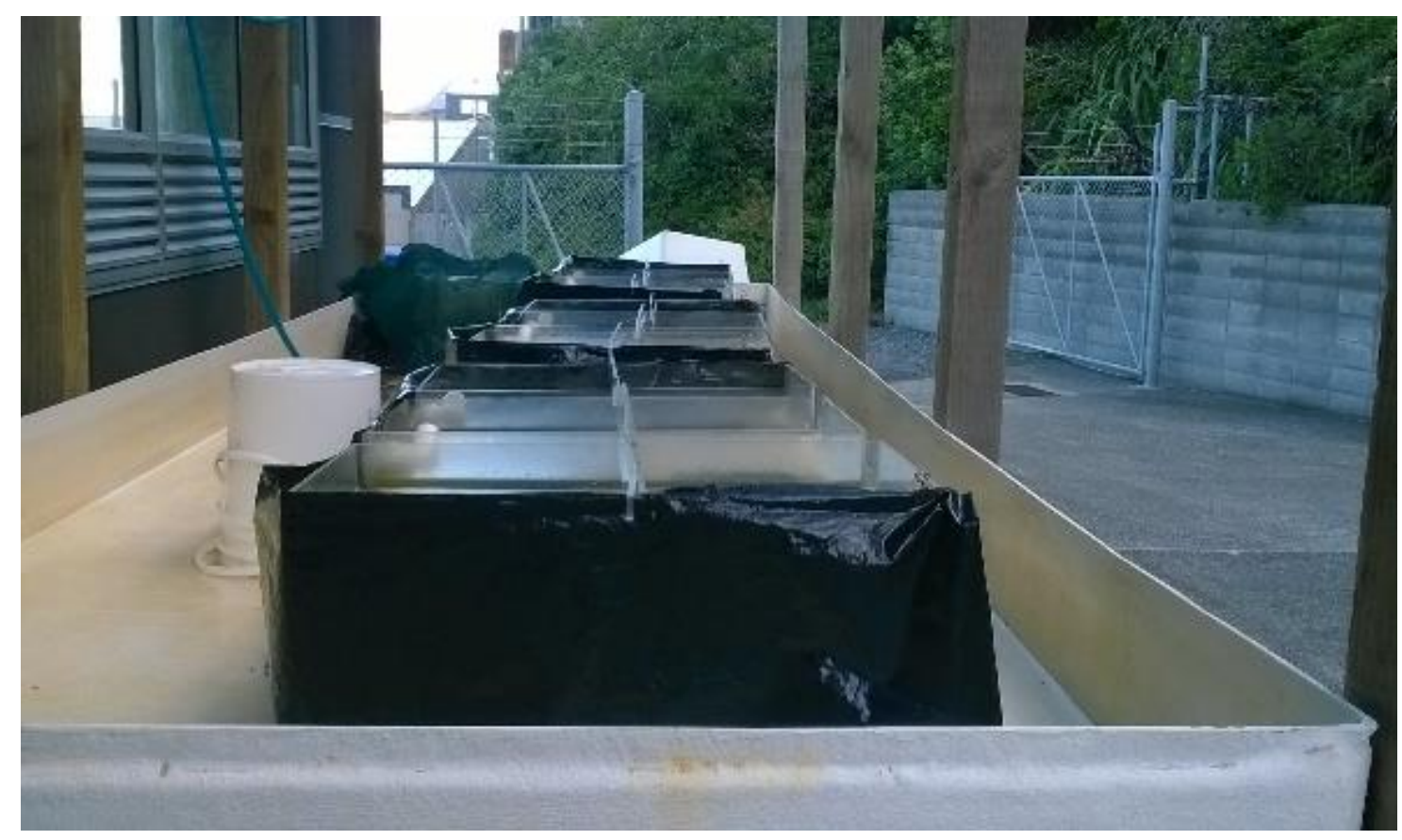

Figure 3.2: Outdoor seatable with the nine Browns Bay tanks wrapped in black plastic. Shade cloth was removed for the photo, but it shaded both the top and front of tanks. The laboratory can be seen to the left.

A three-week acclimation period ran from 14 March to 4 April. The acclimation period allowed time for seagrass to recover from any transplantation stress, or recent nutrient fluxes prior to collection. Epiphytes were removed from seagrass blades, containers and tanks once a week. The alga Polysiphonia spp. was growing on the upper third of blades from this site at the time of collection, and began trapping diatoms. The Polysiphonia 
increased the surface area available for epiphytes to colonise, creating a potential bias for greater epiphyte biomass in containers with greater Polysiphonia loads. Infected tips were fragile and prone to breaking so were removed during the second cleaning on 21 March. Blades were checked for further Polysiphonia growth every day to 25 March to ensure that removal had been effective.

On 4 April, seagrass and containers were cleaned by wiping them with paper towel, and then submerged in an indoor seatable (Figure 3.3). Blades were punctured with a 20-gauge hypodermic needle $1 \mathrm{~cm}$ above the sheath, and the number of shoots per container were counted. As the seagrass grew over the course of the experiment, the puncture mark moved further from the sheath, allowing an estimation of growth by final height of puncture from sheath (e.g. $2 \mathrm{~cm})$ from original height $(1 \mathrm{~cm})$. Similarly, new shoot production was estimated by subtracting the final number of shoots from the initial number. Containers were returned to the indoor seatable until the start of the experiment on 6 April 2016.

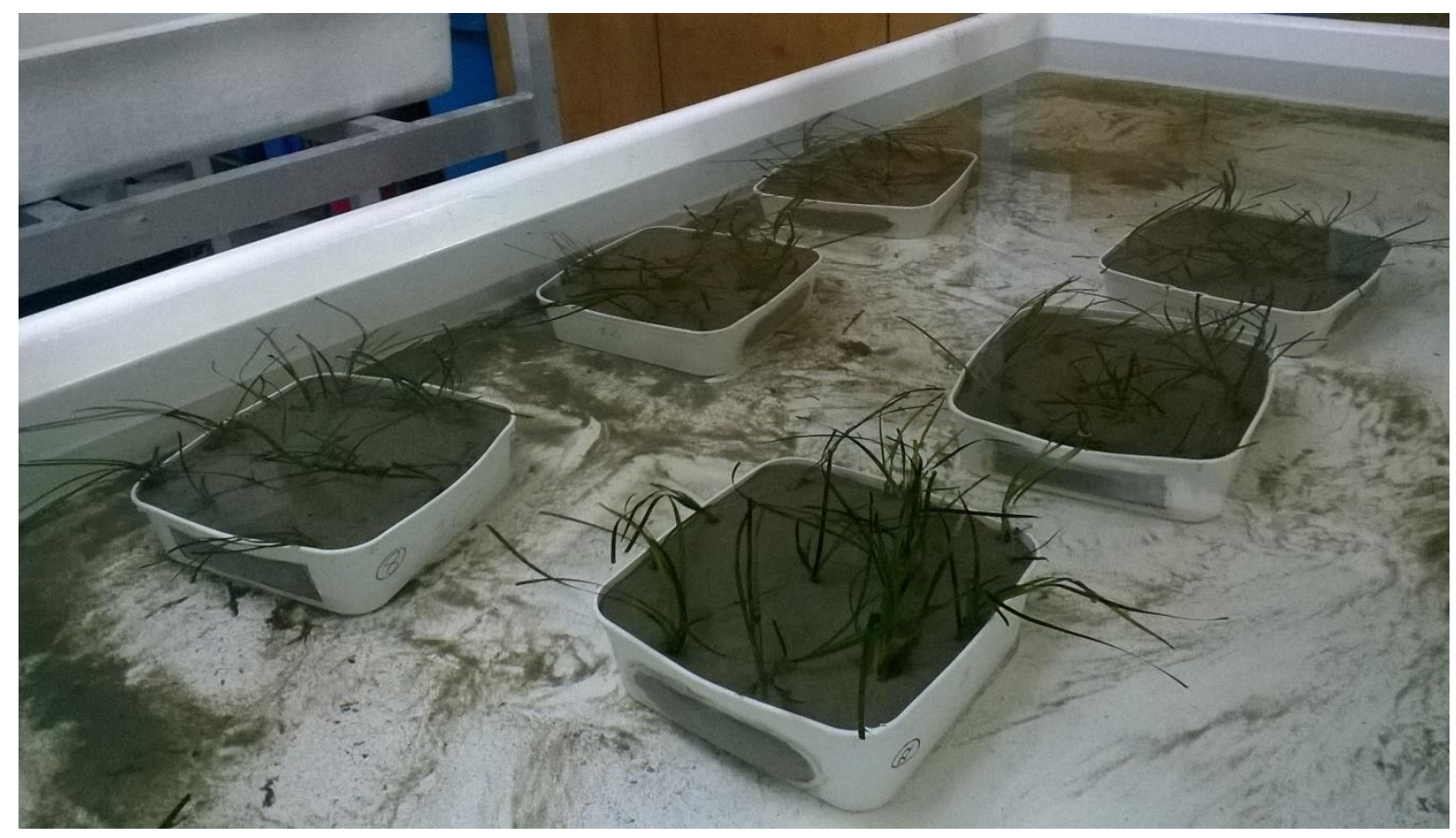

Figure 3.3: Browns Bay seagrass submerged in indoor seatable during transition between threeweek acclimation period and full factorial experiment.

\section{Collection and Acclimation of Seagrass from High Nutrient Input Site (Elsdon)}

All methods for the second run of the experiment using seagrass from Elsdon were largely the same as described above. It was not logistically possible to run the experiments for 
seagrass from the two sites simultaneously, therefore there was a two-month lag between the two runs. The two sites cannot be directly compared and it is possible that any differences in responses of the two sites to experimental treatments might be due to the experiments on seagrass from Elsdon done slightly later in the year. To observe whether seagrass from Browns Bay performed differently in control conditions at this later time, compared to the earlier experimental period, a tenth tank of Browns Bay seagrass (the Reference Tank) was added to the experimental set up. Seagrass was collected from Elsdon and Browns Bay on 5 May. Fresh sediment from Browns Bay and Lyall Bay was collected on 9 May.

Seagrass was kept in tanks with flowing water until planting on 10 and 11 May. Similar shoot densities were used as in the Browns Bay trial, 30 to 35 shoots per container. However, due to the common occurrence of single, healthy shoots attached to a rhizome, planted rhizomes had one to five shoots attached. No black plastic wrap was used in the setup, as there is little direct sunlight on or around the seatable at this slightly later time of year. The shade cloth, however, was still used.

The three-week acclimation period ran from 12 May to 5 June. The seagrass blades, containers and tanks were cleaned of epiphytes once a week. Elsdon seagrass had little to no Polysiphonia spp., or other epiphytes, growing on it. However, almost every blade of the seagrass from Browns Bay was again colonized by Polysiphonia spp.. The blades with the greatest cover were removed (as in the Browns Bay trial), but those with low cover were left. Removal of all blades affected by these epiphytes would have biased the comparison to Browns Bay, as young blades may have been colonised by different epiphytes to older blades (Borowitzka et al., 1990), and may have responded differently to nutrient availability. As with the Browns Bay trial, on 5 June, seagrass and containers were cleaned and submerged in an indoor seatable. Seagrass blades were punctured with a 20-gauge hypodermic needle, $1 \mathrm{~cm}$ above the sheath, and the number of shoots counted. Containers were once again kept in the indoor seatable until the experiment commenced on 7 June 2016.

\section{Nutrient and Gastropod Additions}

Tank position and random treatment assignment was recorded for each set of trials (Table A3.1, Table A3.2, Figure A3.1, Figure A3.2). Nutrients were added to appropriate tanks by 
addition of aliquots of standardised solutions, and thoroughly mixed in. Nutrient addition treatments were always added in the order of High (143 $\mathrm{mg} \mathrm{m}^{-3}$ nitrate, $9 \mathrm{mg} \mathrm{m}^{-3}$ phosphate), High+ (171.6 $\mathrm{mg} \mathrm{m}^{-3}$ nitrate and $10.8 \mathrm{mg} \mathrm{m}^{-3}$ phosphate) to avoid contaminating a lower treatment with extra nutrients. After the first nutrient addition, two haphazardly selected seagrass containers were added to each tank within 10 minutes, and remained in these tanks until the conclusion of the experiment. Three each of Notoacmea scapha and Potamopyrgus estuarinus and one Diloma arida (hereafter collectively referred to as the gastropods) were added to one end of each tank, as decided by a coin toss. Gastropod densities approximated those of Paremata Station (where N. scapha and P. estuarinus cooccurred in greatest densities), with $P$. estuarinus collected from Paremata Station and $N$. scapha and D. arida from Browns Bay within 2 days of seagrass collection. Trials ran for 23 days (Browns Bay: 6 to 29 April, Elsdon: 7 June to 1 July). Average water temperatures were $19.5^{\circ} \mathrm{C}$ during Browns Bay trial, and $16.5^{\circ} \mathrm{C}$ during the Elsdon trial. During the first twoweeks of the Browns Bay trial, N. scapha located near the bottom of the container exteriors were often damaged during water changes, and were replaced within two days.

Water (and nutrients, as appropriate) was replaced every second day. For each tank, the containers of seagrass and the mesh divider were lifted out and placed on trays and taken indoors (out of the sun) while the tank was drained and rinsed with filtered seawater. Tanks were drained by siphoning water through a hose into a $1 \mathrm{~mm}$ sieve over a bucket, to ensure gastropods were not lost. Tanks and dividers were carefully checked for gastropods. After returning containers and the dividers to the refilled tanks, nutrients were added to the appropriate levels and mixed in, beginning with the Control tanks and ending with the High+ tanks, thoroughly rinsing stirring implements between working in each tank. Any shading plastic which had been removed during this process was secured to the tanks in Browns Bay, and the shade cloth placed over the tanks in Browns Bay and Elsdon trials.

On the final day of experiments (Browns Bay: 29 May 2016 and Elsdon: 1 July 2016), containers were removed and stored in large, labelled ziplock bags. Any gastropods in the tank were added to the container. Tanks were emptied as per usual and the last of the water was tipped out after checking for remaining gastropods. Seagrass was removed from containers and carefully rinsed of sediment with tap water over a $1 \mathrm{~mm}$ sieve. Seagrass (shoots, roots and rhizome) was then stored in labelled ziplock bags and frozen. Samples 
were removed individually from the freezer as required for subsequent close examination and soaked in tap water until defrosted (20 to 30 minutes). Blade length was measured (base to tip), stab marks were measured (base to mark), the number of shoots was recorded, and epiphytes from all blades were scraped into a single Eppendorf tube for each container of seagrass. Eppendorf tubes were spun in a centrifuge at $3500 \mathrm{rpm}$ for five minutes, excess water was removed, and epiphytes (within Eppendorf) were weighed. Care was taken to minimise blade detachment throughout the process, but any blades that had detached from shoots were counted as 'detached blades'. These were counted in the total number of blades, but were not counted as separate shoots.

\section{Statistical Analyses}

All analyses were conducted in R V3.3.1 (R Core Team, 2016) using RStudio v0.09.99.903 (RStudio Team, 2015). Due to non-normal distribution and heterogeneity of variance among treatments, PERMANOVA was used to test the effects of nutrient and gastropod treatments on new blade production, blade growth and epiphyte biomass using the aovp function in the ImPerm package (Wheeler and Torchiano, 2016). Shoot density changed between the beginning and end of the experiment. Therefore, the effects of nutrient and gastropod treatments on $\Delta$ shoot density (final - initial shoot counts) between the beginning and end of the experiment were analysed with two-way ANOVA (aov function within the stats package (R Core Team, 2016)). If there was no significant influence of gastropod treatment in the above tests, and no interaction between gastropods and nutrients, then data was pooled across gastropod treatments and the effect of nutrient treatments only were tested in a single factor ANOVA (aov function). Post hoc Tukey tests were run for significant results (TukeyHSD function within the stats package). Pearson's Correlation was used to assess relationships between $\Delta$ shoot density, average growth, average number of new blades produced, epiphyte biomass (log-natural transformed) and number of blades per shoot, using the rcorr function within the Hmisc package (Harrell et al., 2016). The Reference tank (seagrass from Browns Bay tested during the Elsdon trial) was excluded from the above statistical tests. However, the Reference tank was compared to the Elsdon Control tanks, and to the Browns Bay Control tanks, using Welch's t-tests for new blade production, blade growth, epiphyte biomass and $\Delta$ shoots. 


\section{Results}

\section{Blade Production}

Approximately $50 \%$ of blades did not have identifiable stab marks at the end of experiments, and are assumed to be new growth. New blade production in the Browns Bay trial was influenced by nutrient treatment and the interaction between nutrient and gastropod treatments (Table 3.2). Blade production was 1.3 times greater in High+/Gastropod Present than High/Gastropod present (Tukey post-hoc test: $p=0.0271$ ). Control and High+ treatments did not differ between Gastropod treatments (Tukey post-hoc test: $p>0.05$ ), where blade production in the High treatment was 1.3 times lower in Gastropod Present than Absent treatments.

Blade production in the Elsdon trial was influenced by gastropod treatment (Table 3.3). Pooling across nutrient treatments, blade production was on average 1.2 times higher when gastropods were present compared to when they were absent (one-way PERMANOVA: $\operatorname{Pr}(\operatorname{Prob})<0.0001 ;$ Figure $3.4 \mathrm{~b})$. Blade production in the Reference tank was similar to Control treatments in the Browns Bay $(t(116.81)=-0.07, p=0.9404)$ and Elsdon $(t(126.21)=$ $-1.77, p=0.0784$ ) trials.

Table 3.2: Results of two-way PERMANOVA examining the effects of nutrient addition (Control, High, High+) and gastropods (Presence/Absence) on new blade production in the Browns Bay trial.

\begin{tabular}{|l|l|l|l|l|}
\hline Source of Variation & $\mathrm{df}$ & Residual SS. & Iterations & $\operatorname{Pr}$ (Prob) \\
\hline Nutrient & 2 & 7.39 & 5000 & $<0.0001$ \\
\hline Gastropod & 1 & 1.24 & 1420 & 0.0662 \\
\hline Nutrient*Gastropod & 2 & 11.73 & 5000 & $<0.0001$ \\
\hline Residuals & 569 & 394.35 & & \\
\hline
\end{tabular}

Table 3.3: Results of two-way PERMANOVA examining the effects of nutrient addition (Control, High, High+) and gastropods (Presence/Absence) on new blade production in the Elsdon Trial.

\begin{tabular}{|l|l|l|l|l|}
\hline Source of Variation & $\mathrm{df}$ & Residual SS. & Iterations & $\operatorname{Pr}(\operatorname{Prob})$ \\
\hline Nutrient & 2 & 3.51 & 5000 & 0.1018 \\
\hline Gastropod & 1 & 10.99 & 5000 & $<0.0001$ \\
\hline Nutrient*Gastropod & 2 & 4.49 & 3666 & 0.0663 \\
\hline Residuals & 704 & 557.09 & & \\
\hline
\end{tabular}



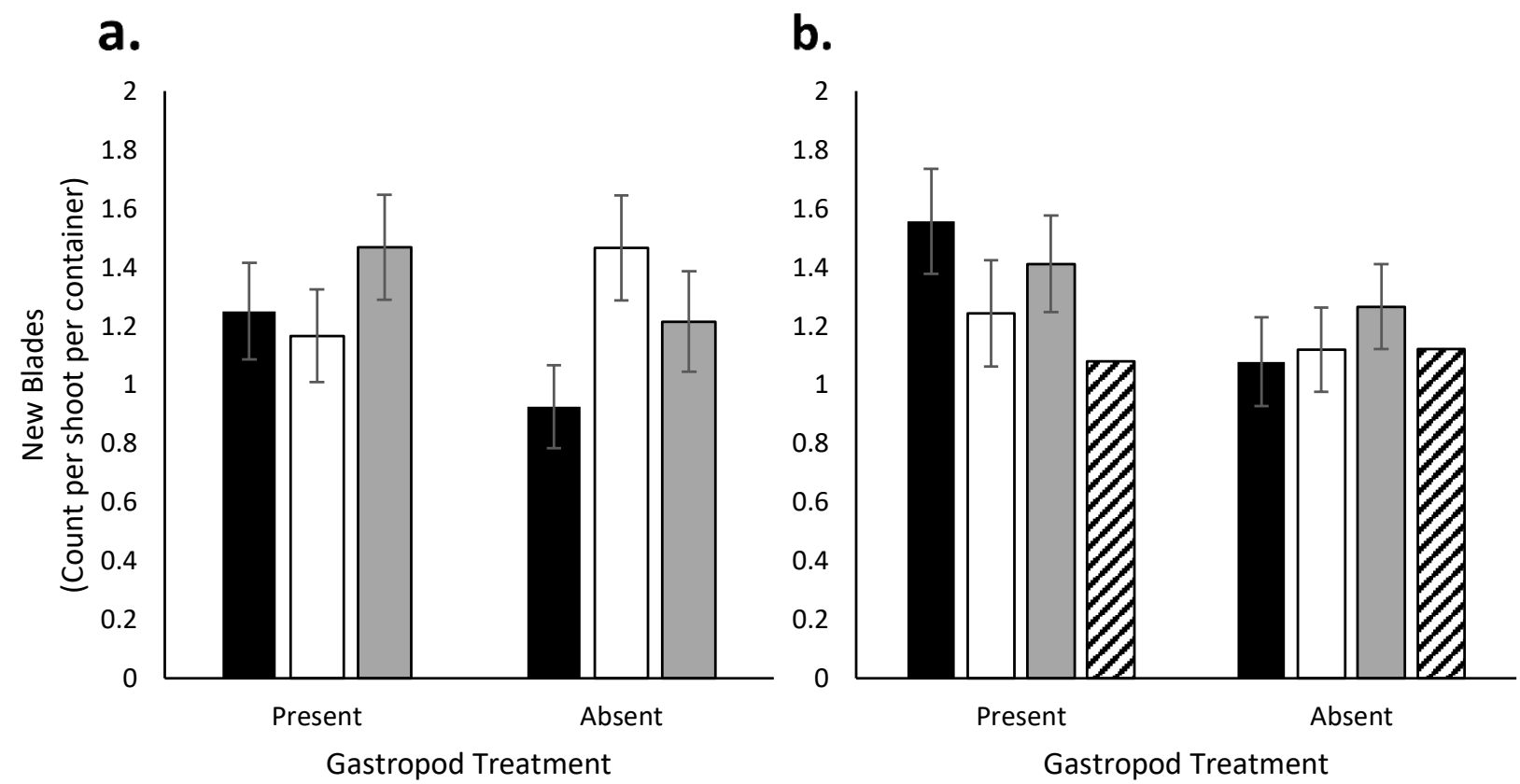

Figure 3.4: Average number of 'new' blades (+/- 95\% confidence intervals) in (a) Browns Bay and (b) Elsdon trials. Black bars represent Control nutrient treatments, open bars represent High, grey bars High+ and the striped bars the Browns Bay Reference tank. $n=6$ for Control, High and High+, $\mathrm{n}=1$ for Browns Bay reference tank (also in control seawater).

\section{Blade Growth}

To analyse blade growth over the 3-week experiment, blades without stab marks were removed before analysing blade growth data, but should be kept in mind, as these new blades may have grown faster or slower than the analysed data. Blade growth was not influenced by gastropod or nutrient treatments in the Browns Bay (Table 3.4) or Elsdon (Table 3.5) trials. Pooling across gastropod treatments, blade growth for Browns Bay was on average $26 \%$ less in High+ compared to Control and High treatments (One-way PERMANOVA: $\operatorname{Pr}($ Prob) $<0.0001 ;$ Tukey post hoc test: $p<0.01$, Figure 3.5a). When pooled across gastropod treatments, Elsdon blade growth remained uninfluenced by nutrient treatments (One-way PERMANOVA: $\operatorname{Pr}(\operatorname{Prob})=0.7399)$. Seagrass in the Control treatments of Browns Bay and Elsdon trials grew at almost twice the rate of Reference tank seagrass (Browns Bay: $\mathrm{t}(151.95)=3.12, \mathrm{p}=0.0022$; Control: $\mathrm{t}(223.67)=5.04, \mathrm{p}<0.0001)$. 
Table 3.4: Results of two-way PERMANOVA examining the effects of nutrient addition (Control, High, High+) and gastropods (Presence/Absence) on blade growth in the Browns Bay trial.

\begin{tabular}{|l|l|l|l|l|}
\hline Source of Variation & $\mathrm{df}$ & Residual SS. & Iterations & $\operatorname{Pr}$ (Exact) \\
\hline Nutrient & 2 & 7043 & 5000 & $<0.0001$ \\
\hline Gastropod (Tank) & 1 & 228 & 114 & 0.4737 \\
\hline Nutrient*Gastropod & 2 & 385 & 319 & 0.3981 \\
\hline Residuals & 671 & 307245 & & \\
\hline
\end{tabular}

Table 3.5: Results of two-way PERMANOVA examining the effects of nutrient addition (Control, High, High+) and gastropods (Presence/Absence) on blade growth in the Elsdon trial.

\begin{tabular}{|l|l|l|l|l|}
\hline Source of Variation & df & Residual SS. & Iterations & $\operatorname{Pr}$ (Exact) \\
\hline Nutrient & 2 & 766 & 576 & 0.2483 \\
\hline Gastropod (Tank) & 1 & 97 & 51 & 0.9804 \\
\hline Nutrient*Gastropod & 2 & 2164 & 311 & 0.2444 \\
\hline Residuals & 999 & 1192932 & & \\
\hline
\end{tabular}

\section{a.}

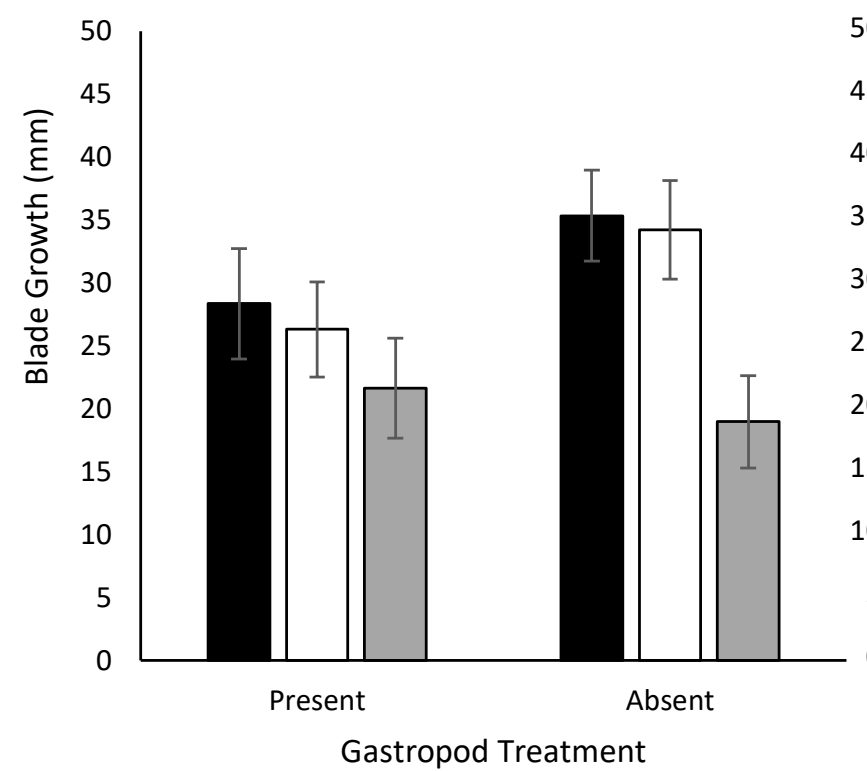

b.

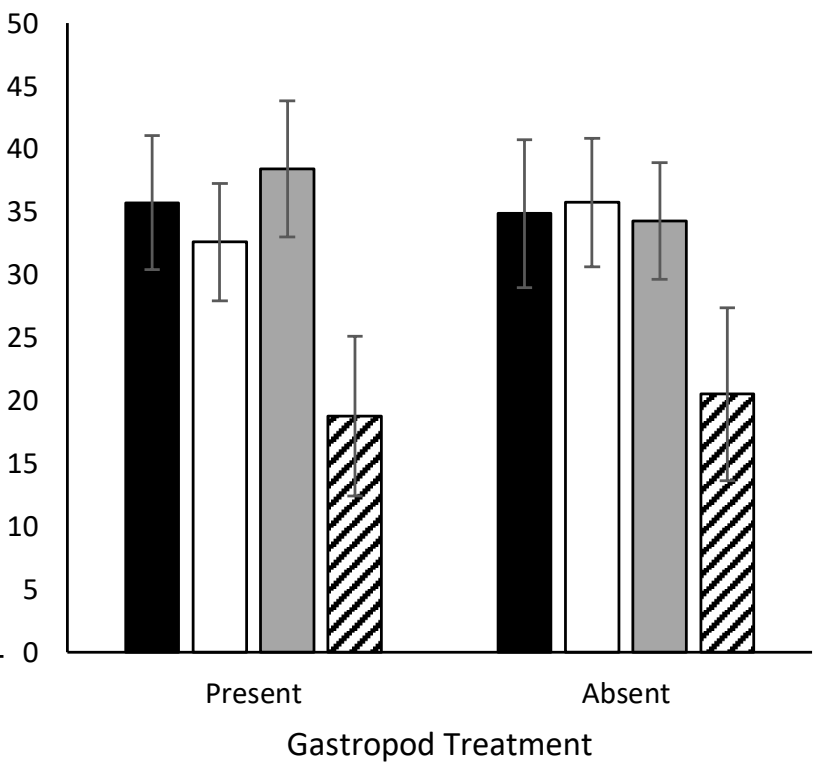

Figure 3.5: Average blade growth over a 3-week period (+/- 95\% confidence intervals) in (a) Browns Bay and (b) Elsdon trials. Black bars represent Control nutrient treatments, open bars represent High, grey bars High+ and the striped bars the Browns Bay Reference tank. $\mathrm{n}=6$ for Control, High and High+, $\mathrm{n}=1$ for Browns Bay reference tank (also in control seawater). 


\section{Epiphyte Biomass}

Epiphyte biomass was not influenced by gastropod or nutrient treatments in the Browns Bay trial (Table 3.6, Figure 3.6a), though epiphyte biomass tended to be greater in the High treatment than Control or High+ when gastropods were present. Removing gastropod effects from the model did not change the non-significance of nutrient treatment effects (one-way PERMANOVA: $\operatorname{Pr}(\operatorname{Prob})=0.078$; Figure 3.6a). Epiphyte biomass was higher and more similar across all treatments in the Elsdon trial (Table 3.7; Figure 3.6b). Pooling across gastropod treatments did not change the non- significant effect of nutrients (one-way PERMANOVA: $\operatorname{Pr}(\operatorname{Prob})=0.8765)$. Pooled across gastropod treatments, the Reference Tank had similar average epiphyte biomass to Elsdon Control $(t(1.24)=-0.0102, p=0.9933)$ and Browns Bay Control $(t(1.12)=-2.10, p=0.2615)$ treatments. The high variation in Browns Bay Control values appears to drive the latter similarity.

Table 3.6: Results of two-way PERMANOVA examining the effects of nutrient addition (Control, High, High+) and gastropods (Presence/Absence) on epiphyte biomass in the Browns Bay trial.

\begin{tabular}{|l|l|l|l|l|}
\hline Source of Variation & df & Residual SS & Iteration & $\operatorname{Pr}(\operatorname{Prob})$ \\
\hline Nutrient & 2 & 168247 & 2384 & 0.0973 \\
\hline Gastropod & 1 & 29 & 51 & 0.9804 \\
\hline Nutrient*Gastropod & 2 & 82939 & 1062 & 0.2316 \\
\hline Residuals & 12 & 369558 & & \\
\hline
\end{tabular}

Table 3.7: Results of two-way PERMANOVA examining the effects of nutrient addition (Control, High, High+) and gastropods (Presence, Absence) on epiphyte biomass in the Elsdon trial.

\begin{tabular}{|l|l|l|l|l|}
\hline Source of Variation & df & Residual SS & Iteration & $\operatorname{Pr}$ (Prob) \\
\hline Nutrient & 2 & 14583 & 172 & 0.7500 \\
\hline Gastropod & 1 & 2813 & 56 & 0.6429 \\
\hline Nutrient*Gastropod & 2 & 129082 & 3277 & 0.1041 \\
\hline Residuals & 12 & 294604 & & \\
\hline
\end{tabular}




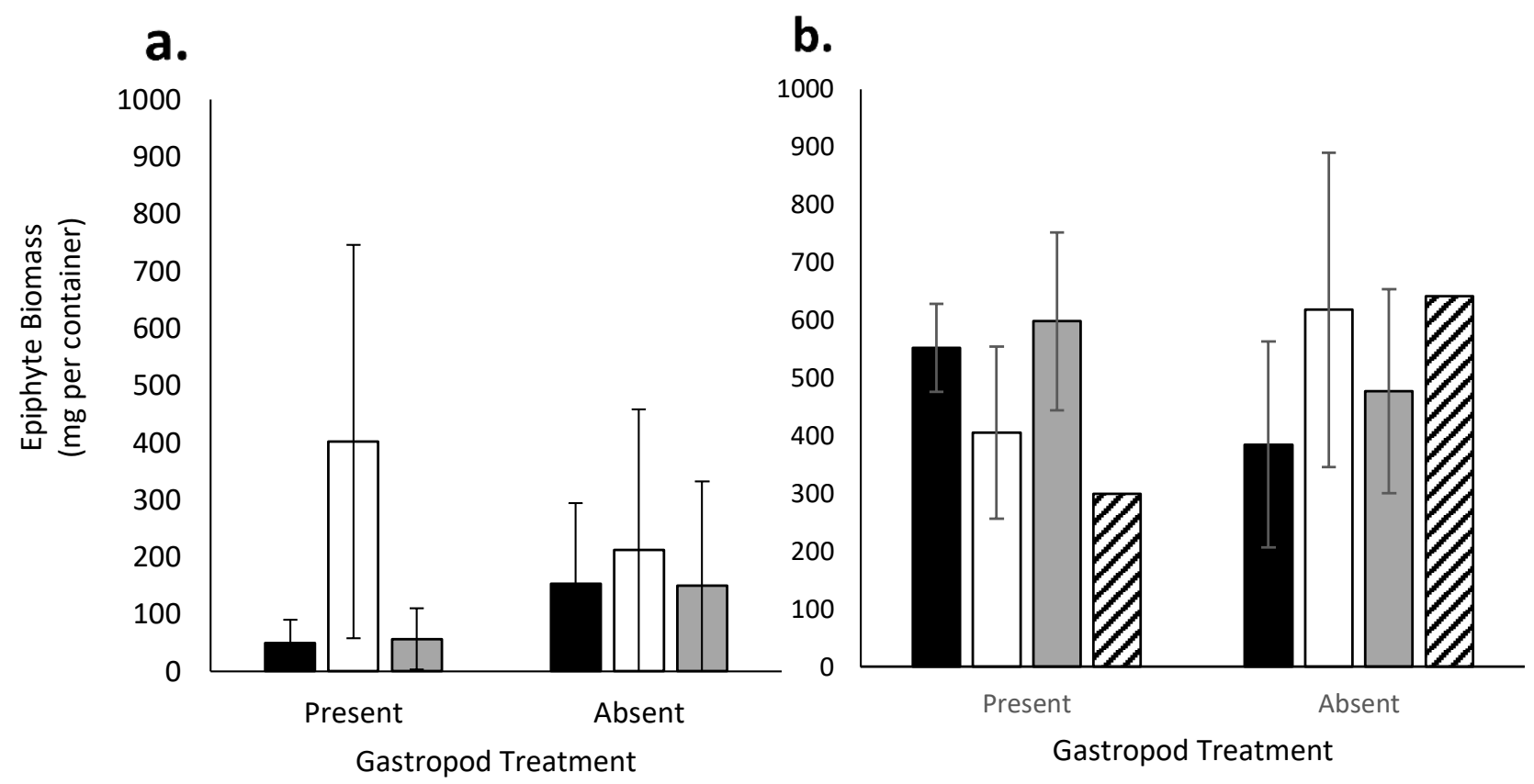

Figure 3.6: Average epiphyte biomass (+/- 95\% confidence intervals) in (a) Browns Bay and (b) Elsdon trials. Black bars represent Control nutrient treatments, open bars represent High, grey bars High+ and the striped bars the Browns Bay reference tank. $n=3$ for Control, High and High,$+ n=1$ for Browns Bay reference tank.

\section{$\underline{\Delta \text { Shoot Density }}$}

In the Browns Bay trial, most containers showed increased $\Delta$ shoot density (range $=-1$ to +16 , mode $=6) . \Delta$ shoot density was highly variable and did not vary significantly between treatments (Table 3.8, Figure 3.7a). Pooling across gastropod treatments made the effects of nutrient addition almost significant, with a trend for reduced shoot density in the highest nutrient treatment (one-way ANOVA: $F_{2,15}=3.4, p$-value $=0.0617$ ). $\Delta$ shoot density in the Elsdon trial included several negative values (i.e. reduced shoot density) (range $=-7$ to +17 , mode $=8$ ). Elsdon shoot density showed an interaction between nutrient and gastropod treatments, with 35 times the average density of High/Gastropods Absent than High/Gastropods Present (Table 3.9, Figure 3.7b). However, Control/Gastropods Present had 8.6 times the average $\Delta$ shoot density of Control/Gastropods Absent (Table 3.9, Figure 3.7b). There were a similar number of shoots at the beginning and end of the experiment in the Reference tank. Likely due to the high variation in Elsdon Control treatment tanks, and few Reference replicates, both showed similar average $\Delta$ shoot densities $(\mathrm{t}(5.14)=1.96, \mathrm{p}=$ 0.1062). However, Browns Bay Control tanks had much greater average shoot changes than the Reference tank $(t(5.83)=5.58, p=0.0015)$. 
Table 3.8: Results of two-way ANOVA examining the effects of nutrient addition (Control, $\mathrm{High}, \mathrm{High+}$ ) and gastropods (Presence/Absence) on $\Delta$ shoot density in the Browns Bay trial.

\begin{tabular}{|l|l|l|l|l|}
\hline Source of Variation & $\mathrm{df}$ & SS & F-value & p-value \\
\hline Nutrient & 2 & 145.33 & 3.042 & 0.0854 \\
\hline Gastropod & 1 & 20.06 & 0.840 & 0.3776 \\
\hline Nutrient*Gastropod & 2 & 16.44 & 0.344 & 0.7156 \\
\hline Residuals & 12 & 286.67 & & \\
\hline
\end{tabular}

Table 3.9: Results of two-way ANOVA examining the effects of nutrient addition (Control, $\mathrm{High}, \mathrm{High+}$ ) and gastropods (Presence/Absence) on $\Delta$ shoot density in the Elsdon trial.

\begin{tabular}{|l|l|l|l|l|}
\hline Source of Variation & df & SS & F-value & -value \\
\hline Nutrient & 2 & 6.3 & 0.090 & 0.9142 \\
\hline Gastropod & 1 & 14.2 & 0.406 & 0.5361 \\
\hline Nutrient*Gastropod & 2 & 280.8 & 4.005 & 0.0465 \\
\hline Residuals & 12 & 420.7 & & \\
\hline
\end{tabular}
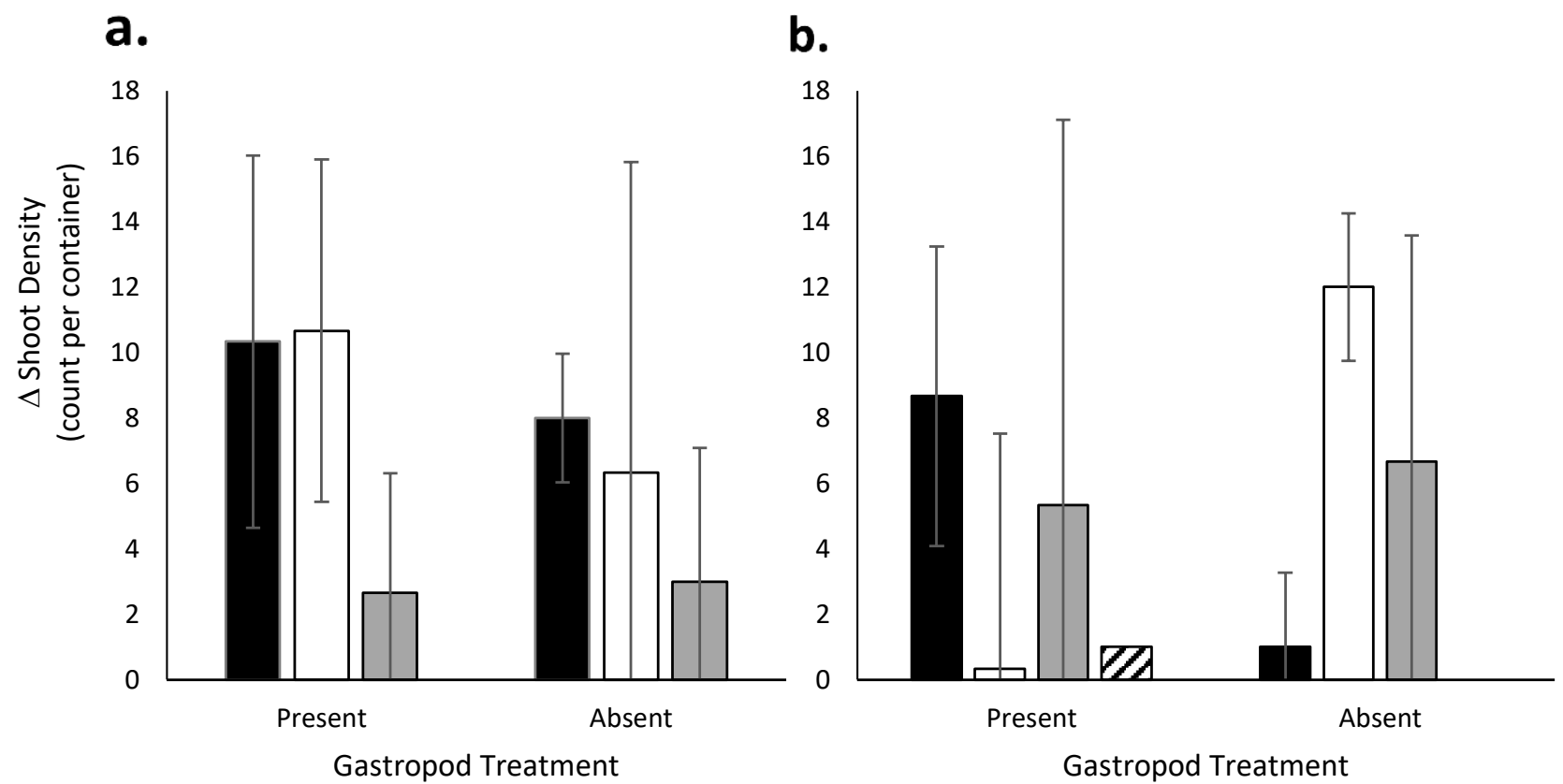

Figure 3.7: Average (+/- 95\% confidence intervals) change in shoot density between the beginning and end of (a) Browns Bay and (b) Elsdon trials. Black bars represent Control nutrient treatments, open bars represent High, grey bars High+ and the striped bars the Browns Bay reference tank. $\mathrm{n}=3$ for Control, High and High+, $\mathrm{n}=1$ for the Reference tank. 


\section{$\underline{\text { Relationship Between Seagrass Attributes }}$}

There were no significant correlations between $\Delta$ shoot density and number of blades, average growth or average blade production in Browns Bay or Elsdon trials. In the Browns Bay trial only, there was a correlation between average growth and number of blades $(r=0.52, n=18, p=0.0275 ;$ Figure 3.8$)$ and average blade production and number of blades $(r=0.47, n=18, p=0.0491 ;$ Figure 3.9). Both average blade growth and average blade production increased with the number of blades per container. There was also a correlation between epiphyte biomass and number of blades in the Elsdon trial $(r=0.51, n=18$, $p=0.0291$; Figure 3.10), where epiphyte biomass increased with the number of blades.

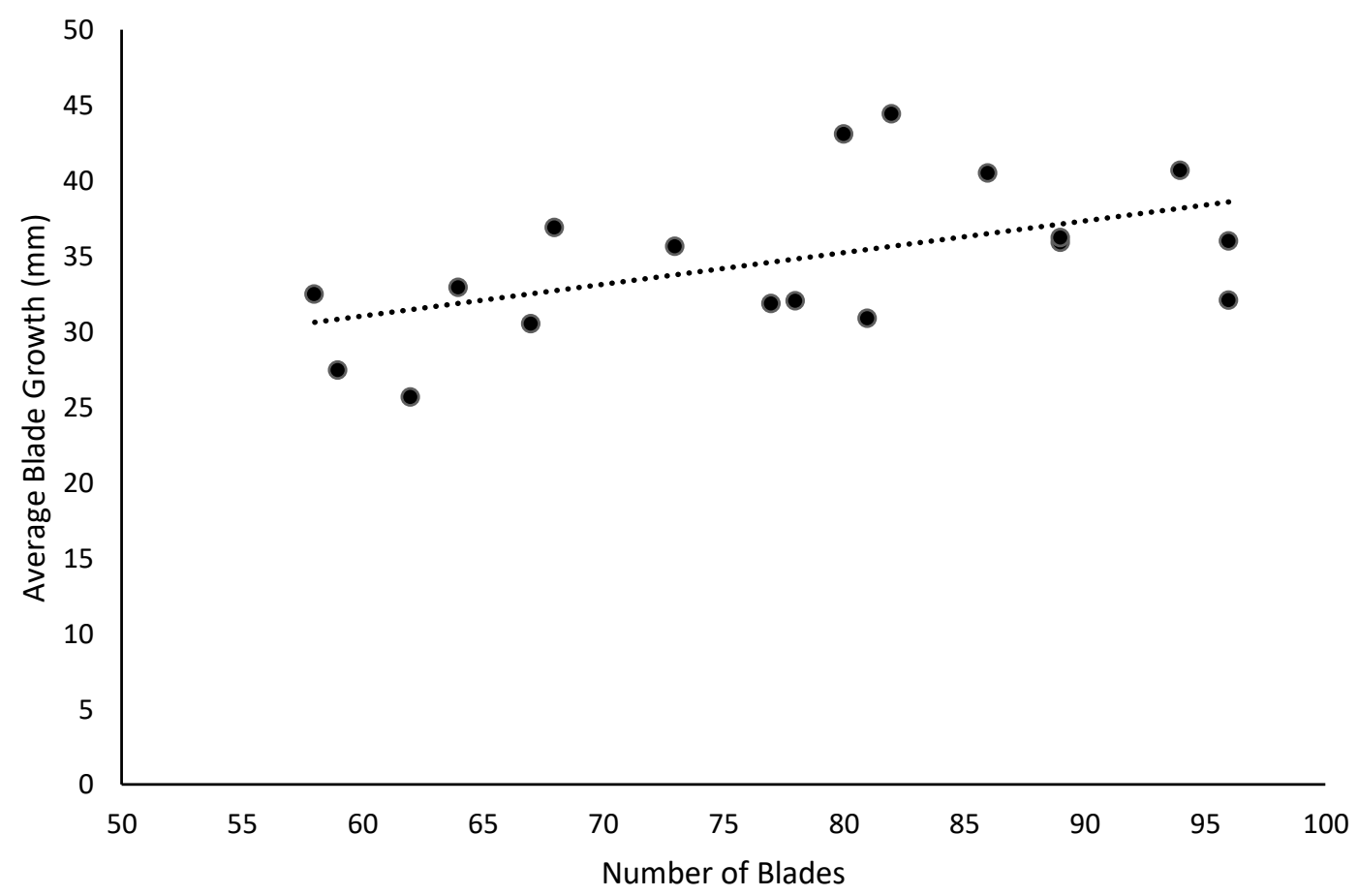

Figure 3.8: Relationship between number of blades per container and average seagrass blade growth $(\mathrm{mm})$ in the Browns Bay trial. $\mathrm{n}=18, \mathrm{y}=0.2099 \mathrm{x}+18.44$. 


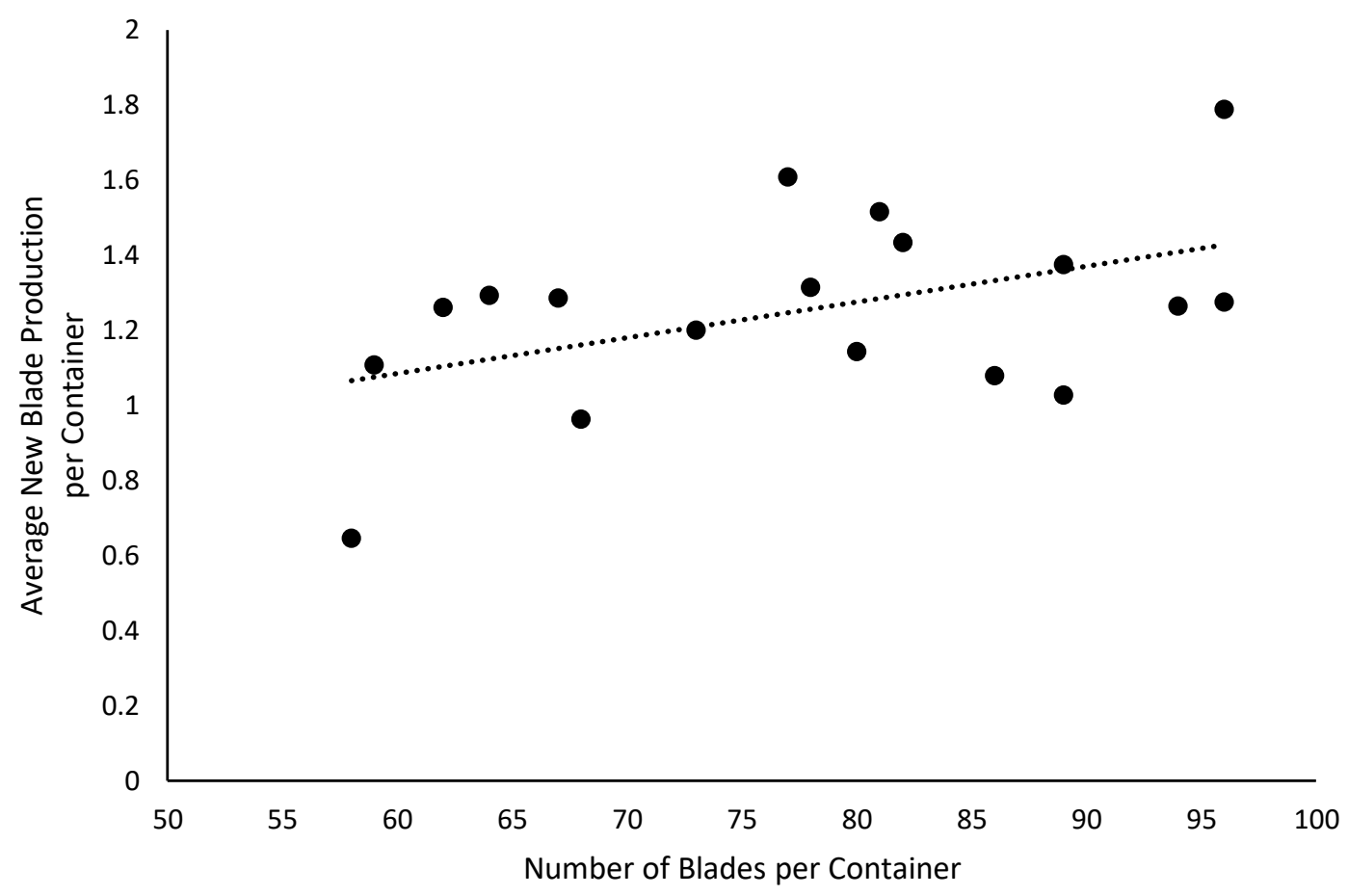

Figure 3.9: Relationship between number of blades per container and average new blade production per container in the Browns Bay trial. $n=18, y=0.0095 x+0.5143$.

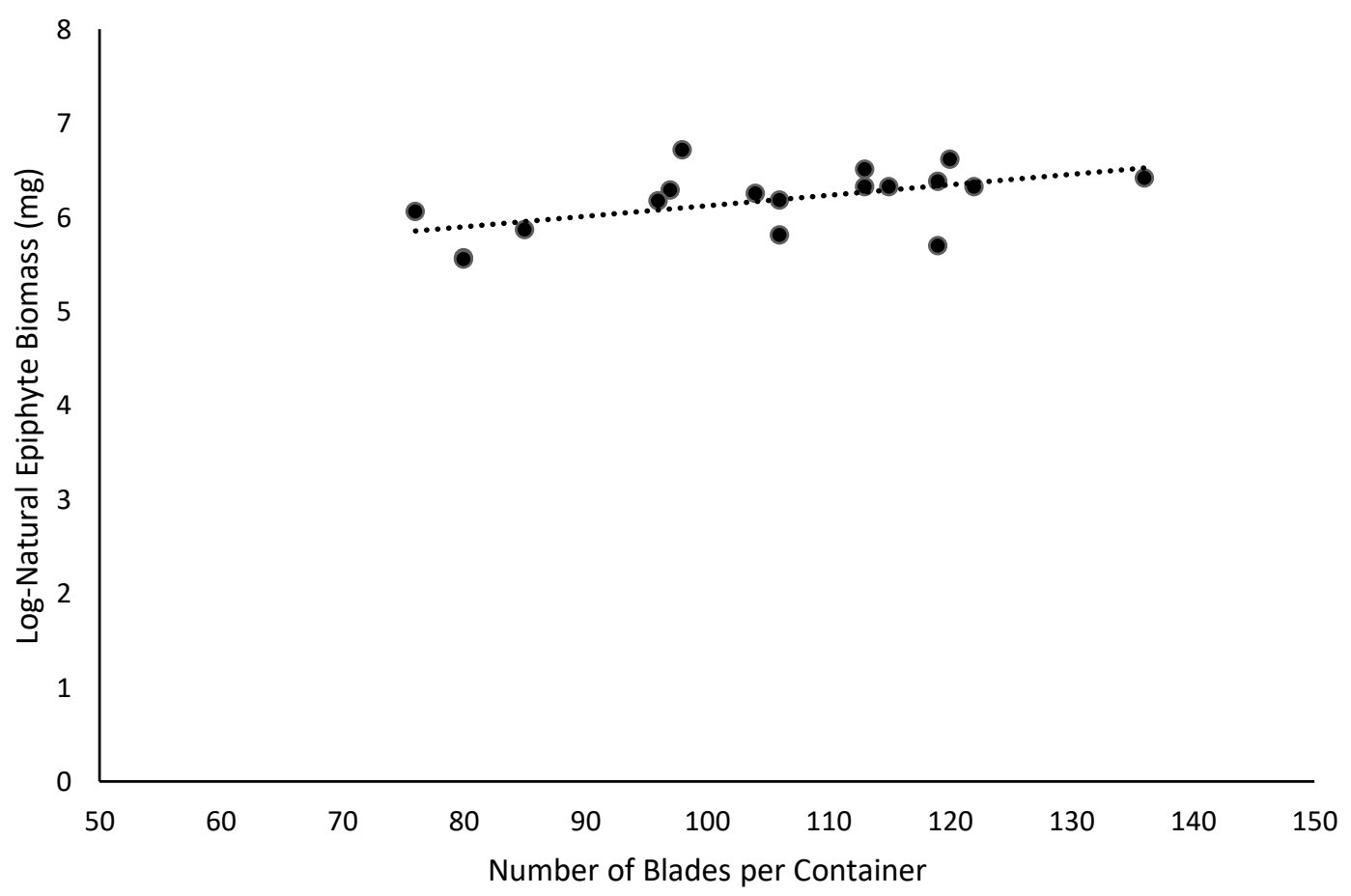

Figure 3.10: Relationship between number of blades per container and epiphyte biomass in the Elsdon trial. $\mathrm{n}=18, \mathrm{y}=0.0112 \mathrm{x}+5.0035$. 


\section{Discussion}

This study found no strong evidence for effects of nutrient addition, or grazers, on seagrass or epiphytes and no patterns consistent across the two sites. Inferentially, the greatest differences appeared to occur across the two sites, though this could not be statistically examined due to the slight offset in experiment timing. However, trends for overall higher blade growth and epiphyte loads (almost double) occurred on seagrass from Elsdon. For seagrass from Browns Bay, the High+ treatment resulted in reduced growth and shoot density compared to Controls, possibly indicative of toxic effects. However, this could also be due to seagrass diverting energy to producing new blades. Elsdon seagrass grew more than that of Browns Bay over the three-week experiment, and barely responded to nutrient addition. This may be due to growth rate already being maximal, and/or that its adaptations to the light and nutrient availability at Elsdon made it well adapted to the experimental conditions.

Contrary to hypotheses, epiphyte biomass did not respond consistently to nutrient or gastropod treatments, nor did it hinder seagrass growth in either trial. The lack of relationship between epiphyte biomass and blade growth or shoot density in either trial indicates that there was little to no light limitation by epiphytes. This is not an uncommon finding, as seagrass can grow for over 55 days with only $5 \%$ of surface irradiance (Abal et al., 1994). Browns Bay High nutrient treatments had the greatest epiphyte biomass as well as seagrass blade growth, yet Control and High+ treatments (which differed in blade growth) had similar epiphyte biomasses. There were no consistent trends in epiphyte biomass across Elsdon nutrient treatments, though the presence of gastropods in Control and High+ treatments seemed to have a positive effect on epiphyte biomass in this trial. There may be evidence of epiphyte control by grazers in the High nutrient treatment, but this is confused by the lack of effect of grazers in the Control treatment.

The substantially greater epiphyte biomass in the Reference tank compared to Browns Bay trial treatments is unlikely to be due to changes in the base (i.e. coastal) seawater nutrient levels, as these are low year round (Morelissen, 2012). The difference in biomass could indicate temporal variation in epiphyte assembly. Whatever the cause, the (non-significant) higher epiphyte loads in the Reference tank compared to Browns Bay Control treatments may have inhibited blade growth, which was half that of Browns Bay Controls. Lack of effect 
of treatments on epiphyte biomass may be explained in several ways. Epiphyte biomass does not always increase with nutrient availability (Bourque and Fourqurean, 2014; Campbell and Fourqurean, 2014), and even the better-studied amphipod grazers cannot always control epiphytes (Campbell and Fourqurean, 2014; McSkimming et al., 2015). In the present study, water (and likely algal recruits) was obtained from a very different environment to the Porirua Harbour. The palatability and type of algae may therefore have been unlike that of the Porirua Harbour environment.

Gastropods were often observed grazing biofilm from the tank and container sides or the mesh divider. Given that the feeding apparatus of $N$. scapha and P. estuarinus appear to limit them to grazing micro-epiphytes (biofilm and very small algal recruits) ( $P$. estuarinus: Winterbourne and Fegley, 1989; N. scapha: Nakano and Spencer, 2007), this abundance of biofilm on non-seagrass surfaces appears to have been preferable to biofilm on seagrass blades. The absence of predators in this experiment may have also influenced grazer choice, where instead of keeping within the relative safety of seagrass blades (Alfaro, 2006a), grazers foraged in the open. Epiphyte biomass increased more slowly in Control treatments of both Browns Bay and Elsdon trials, than in the nutrient addition treatments (pers. obs.). It is possible, therefore that there was a limit to epiphyte biomass besides nutrient availability or gastropod control within each container.

On rocky shores, exclusion of limpets and other herbivorous gastropods from areas of little to no algae results in increased algal biomass over time (Arrontes et al., 2004; BenedettiCecchi et al., 2000; Jenkins et al., 2005; Phillips and Hutchison, 2008). When allowed to return, limpets cannot graze away the macroalgae, as the small size of their mouthparts makes them physically incapable of removing more than biofilm and algal recruits (Jones, 1946). D. arida can consume macroalgae, but may not have occurred in sufficient densities, or may have preferred biofilms, thereby having no discernible effect on epiphytes. Wiping down the sides of tanks every second day (as in Duffy et al., 2015) may also have clarified trends by forcing gastropod grazers to remove biofilm from seagrass blades, thereby preventing colonisation by larger epiphytes. Alternatively, other members of the community may play a role in epiphyte control. Furthermore, increased epiphyte production in a natural setting would likely attract additional grazers, support higher grazer populations, or allow increased per capita grazing (as seen in McSkimming et al., 2015). 
The change in shoot density between the beginning and end of the experiment was highly variable both within and between treatments in both Browns Bay and Elsdon trials.

Changes in shoot density have been linked to several factors, including light availability (e.g. Abal et al., 1994; Attrill et al., 2000; Jorgensen et al., 2007; Kim et al., 2013; Miller et al., 2005) and plant stress (e.g. nutrient toxicity (van Katwijk et al., 1997)). It is interesting to note that the variation around the average $\Delta$ shoot density was lower in Gastropod Present than Gastropod Absent treatments for the Browns Bay trial. Elsdon High treatments showed evidence of grazer control, yet the opposite trend in Control. The biggest differences between the abiotic conditions of trials were the light availability and water temperature. Water temperature was lower in the Elsdon trial than Browns Bay (average: $16.5^{\circ} \mathrm{C}$ and $19^{\circ} \mathrm{C}$ respectively). Lower temperatures may have reduced grazer activity, allowing greater epiphyte biomass accumulation.

Though blade growth is positively correlated with temperature, it is also more strongly correlated with longer days and higher solar radiation (Kerr and Strother, 1989, 1990). During the Browns Bay trial, the seatable was exposed to direct sunlight for at least 4 hours per day. During the Elsdon trial, however, the seatable experienced less than 4 hours of direct sunlight per day, due to a cliff behind the laboratory blocking the lower-positioned sun. Furthermore, there was greater cloud cover during the Elsdon than Browns Bay trial. To minimise these seasonal differences in light availability, the plastic wrap was used in the Browns Bay trial only. The positive relationship between average blade growth and number of blades indicates that Browns Bay seagrass did not experience light limitation. The comparison of the Reference tank to Browns Bay and Elsdon Control treatments demonstrates that seagrass from Elsdon grew faster than that of Browns Bay. Seagrass at Elsdon declined from a single 5.5 ha meadow in 1962 to 1.5 ha across two distinct meadows in 2008 (Matheson and Wadha, 2012). The Elsdon meadow that seagrass was collected from did not exist in the 1960 's, and is $<70 \mathrm{~m}^{2}$ (pers. obs.), so it may be a single clone, or have very low genetic diversity. If the Elsdon seagrass used in experiments was harvested from a single clone, it may be genetically predisposed to faster growth rates than seagrass from Browns Bay. However, there has been no research into the genetic diversity of seagrass within the Porirua Harbour, so it is possible that the seagrass meadows across the sites are genetically similar. Alternatively, Elsdon seagrass may have benefited from 
experimental conditions, such as higher light availability than experienced in the field, where Browns Bay did not.

Results may have been clearer if the experiment lasted longer, as three weeks is at the short-end of such experiments. However, Ebrahim et al. (2014) working in an Australian estuary found significant differences in shoot height and density between crossed nutrient and grazer exclusion treatments within 3 weeks. Seagrass growth, however, did not differ between treatments with approximately $1 \mathrm{~cm}$ growth over 3 weeks of summer. This growth rate is two to four times slower than those observed during the present study. In contrast, the growth rate of seagrass in northern New Zealand meadows was slightly faster than that of the present study, with average growth rates of 1.8 to $3.1 \mathrm{~mm}$ per blade per day in winter (Turner, 2007), compared to 0.9 to $1.7 \mathrm{~mm}$ per treatment per day in the present study. This slower growth is likely due to lower average temperatures in Wellington than the Coromandel Peninsula. Growth rates along the Coromandel were generally higher in summer than winter ( 2.0 to $4.2 \mathrm{~mm}$ per blade per day compared to 1.8 to $3.1 \mathrm{~mm}$, respectively), and highly variable between sites (Turner, 2007), making comparisons between different regions tenuous. However, this does not explain why the Australian seagrass grew slower.

The above studies (Ebrahim et al., 2014, Turner, 2007, the present study) used similar methods of marking blade growth with punctures, which is considered an effective method (Kowalski et al., 2001). However, it should be noted that the absence of a puncture mark in the present study could be due to the blade healing or not being punctured in the first place. Such occurrences are likely in the minority, and blade production (mean: 1.3 for both trials, range $0-6$ ) over the three weeks is comparable to other studies (Hasegawa et al., 2007; Solana-Arellano et al., 2010; Vermeer and Hunte, 2008). However, this is highly species specific (Duarte, 1991) and site specific (Kaldy et al., 1999), and no estimates for New Zealand seagrass could be found.

Results may also have been clearer with greater densities of gastropod grazers. Logistical constraints limited the experiment to only presence/absence, so intermediate densities were chosen for gastropod present treatments. Gacia et al. (2009) used Bittium reticulatum and Jujubinus striatus densities equal (10 individuals per $\left.400 \mathrm{~cm}^{2}\right)$ to and double those $(20$ individuals per $400 \mathrm{~cm}^{2}$ ) of the field in their nutrient addition experiment. Epiphyte biomass 
declined by up to $70 \%$ with these grazers present, particularly when both grazers were present (10 individuals of each species). Similarly, Hily et al., (2004) used field densities of Gibbula umbilicalis and J. striatus (9 individuals), finding both to be highly efficient epiphyte grazers, though the latter had a higher specific grazing rate. Due to the much smaller sizes of $N$. scapha and P. estuarinus than these gastropods, their densities may have needed to be at least 10 individuals per container for their grazing to have a similarly strong effect.

The loss of invertebrates has previously been linked to eutrophication (reviewed by Burkholder et al., 2007; Daudi et al., 2012; McSkimming et al., 2015), accompanied by detrimental flow-on effects to the wider system (Bloomfield and Gillanders, 2005). The High+ treatment exceeds reported levels within the Porirua Harbour, indicating that populations are therefore unlikely to decline even with modest further eutrophication of the system. The lack of interaction or gastropod-only effects also indicate that transplantation efforts to sites of historic seagrass (as have been performed by local volunteers, councils and scientists within the harbour) will not be improved by transplanting the gastropods also.

The nutrient concentrations used in this experiment are fairly high, though not extreme, within the literature. For example, McSkimming et al. (2015) used $51 \mathrm{mg} \mathrm{m}^{-3}$ dissolved inorganic nitrogen (DIN) (minor) and $91 \mathrm{mg} \mathrm{m}^{-3}$ DIN (moderate) in their in-situ experiment, compared to the $143 \mathrm{mg} \mathrm{m}^{-3}$ and $172 \mathrm{mg} \mathrm{m}^{-3} \mathrm{NO}_{3}$ of the present study. Gacia et al. (2009) used slow release fertiliser to create nutrient levels of $62 \mathrm{mg} \mathrm{m}^{-3} \mathrm{NO}_{3}$ and $3 \mathrm{mg} \mathrm{m}^{-3} \mathrm{PO}_{4}$ in Fenals Point (north-western Mediterranean Sea). However, many studies that use slowrelease fertilisers utilise $<2 \mathrm{~g} \mathrm{~N} \mathrm{~m}^{-2} \mathrm{~d}^{-1}$ and $<1 \mathrm{~g} \mathrm{P} \mathrm{m}^{-2} \mathrm{~d}^{-1}$ (Armitage and Fourqurean, 2006; Armitage et al., 2005; Campbell and Fourqurean, 2014). As reported by Matheson and Wadha (2012), nutrient concentrations are high compared to other New Zealand estuaries, and exceed management limits for Chesapeake Bay, USA (Batiuk et al., 1992; Dennison et al., 1993). The Tauranga Harbour (In New Zealand's upper North Island) averaged <29 mg $\mathrm{m}^{-3}$ DIN and $<9 \mathrm{mg} \mathrm{m}^{-3}$ DRP between 1990 and 2010 (Park, 2011). Similarly, the Whangarei Harbour has less than $10 \mathrm{mg} \mathrm{NO}_{3} \mathrm{~m}^{-3}$ (Matheson et al., 2009). 


\section{Conclusion}

This study found little support for gastropods acting as major epiphyte regulators. Furthermore, nutrient treatments showed no consistent effect on seagrass growth, epiphyte biomass or $\Delta$ shoot density, contributing to the argument that seagrass tolerates a wide range of abiotic conditions. Seagrass from a site with consistently elevated nutrients was confirmed more tolerant to elevated nutrients than a site with low ambient nutrient levels. However, epiphyte biomass was not consistently affected by nutrient addition, nor did it hinder growth rates in either trial. The differing responses of seagrass obtained from the two sites does, however, support the conclusion that management efforts should incorporate the site scale, rather than focusing on the harbour as a whole. Further experiments on gastropod grazers, ideally in a field setting, are required to elucidate varying roles and contributions of grazers in the Porirua Harbour. 


\section{General Discussion}

Understanding how seagrass varies temporally and spatially is important for effective management and restoration efforts. Temporal variation in seagrass health and abundance has been linked to changes in temperature, solar radiation and nutrient levels, among other factors (Hasegawa et al., 2007; Kim et al., 2012; Nelson and Waaland, 1997; Turner and Schwarz, 2006; Wong et al., 2013). Seagrass biomass, rhizome complexity, blade growth and blade length vary seasonally, usually peaking in spring/summer (Bulmer et al., 2016; Carstensen et al., 2016; Clausen et al., 2014; Gacia and Duarte, 2001; Hily et al., 2004; Hovey et al., 2012; Kaewsrikhaw et al., 2016; Turner and Schwarz, 2006; Wong et al., 2013), as was found in Chapter 2. Seagrass is highly adaptive, capable of growing in extremely low light levels (e.g. <5\% surface irradiance, Abal et al., 1994), across a wide range of temperatures, e.g. $-1^{\circ} \mathrm{C}$ to $+30^{\circ} \mathrm{C}$ (Bulthuis, 1987; reviewed by Greve and Binzer, 2004) and nutrient gradients (e.g. Jorgensen et al., 2007; Thormar et al., 2016; Leopardas et al., 2016), as well as areas of high sediment suspension (Miller et al., 2005). Physiological acclimation to such conditions can lead to 'ecotypes' (areas of seagrass that are genetically similar but differ physiologically), even within a site (e.g. Sandoval-Gil et al., 2014), resulting in high spatial variation of physical characteristics, such as blade area.

Variation in seagrass cover can impact associated meiofauna (van Houte-Howes et al., 2004), with differing assemblages between continuous and fragmented meadows (Mills and Berkenbusch, 2009), and between seagrass and bare substrates (Connolly, 1994). Little is known about the ecology of gastropod or crustacean grazers associated with seagrass in New Zealand, even though they dominate the invertebrate assemblages of seagrass meadows in several harbours (Alfaro, 2006a; Alfaro, 2006b; Alfaro et al., 2006; Paavo et al., 2012; Rowden et al., 2012). These grazers, both in New Zealand and other systems, predominantly consume algal material (Alfaro et al., 2006; Gacia et al., 2009; Leduc et al., 2009) and/or seagrass detritus (Jeong et al., 2012; Sola, 1996). While they do not directly influence seagrass, such as by consuming living seagrass tissue, their abundance suggests that they may have important roles within the system.

In this study, I found that the predominant gastropods associated with seagrass blades in a large harbour in the lower North Island were the snails Potamopyrgus estuarinus, Diloma 
spp. and Micrelenchus spp., and the limpet Notoacmea scapha. The relative abundances of these snails were varied within and among sites ( $<4 \mathrm{~km}$ apart) and two seasons (Chapter 2). They peaked in summer, a trend reported in previous invertebrate surveys (e.g. Bloomfield and Gillanders, 2005; Edgar, 1990; Nelson and Waaland, 1997). Seagrass meadows are considered to be predominantly regulated by top-down forces, where reductions in gastropod and/or crustacean grazer densities lead to increased epiphyte biomass (Duffy et al., 2015; Ebrahim et al., 2014; Gacia et al., 2009; Heck and Valentine, 2006; Hily et al., 2004; Jernakoff and Nielsen, 1997; Reynolds et al., 2015; Verhoeven et al., 2012). The dominant gastropod grazers of the Porirua Harbour appear to consume biofilm (Miller and Poulin, 2001; Nakano and Spencer, 2007; Winterbourn and Fegley, 1989). The winter increase in epiphyte biomass corresponded with a reduction in grazer densities (Chapter 2), suggesting a strengthening of bottom-up effects simultaneous with the reduction in grazers (i.e. reduced top-down control).

Contrary to predictions, grazers did not control epiphyte biomass in laboratory experiments, though some treatments showed slight trends that supported this idea. For example, epiphyte biomass was (non-significantly) lower in Gastropod Present than Absent treatments within Control and High+ nutrient treatments in the Browns Bay trial, but the opposite occurred in the High nutrient treatment. Previous studies have linked a lack of grazer control to bottom-up forces (i.e. nutrient addition) allowing epiphyte growth to exceed grazer control (McSkimming et al., 2015; Thormar et al., 2016; Zakhama-Sraieb et al., 2006) or for other reasons such as epiphyte unpalatability (see review by Valentine et al., 2002), or predation on grazers (Carr and Boyer, 2014; Jorgensen et al., 2007). These latter two influences may have been at play in the experiments, with algal spores introduced to tanks in the seawater being unpalatable to grazers, and thereby establishing on blades. Alternatively, the lack of predators may have been an influence, with gastropods leaving the relative safety of seagrass blades to remove biofilm on the tank and container walls, instead of seagrass blades.

A positive correlation between nutrient availability and epiphyte loads is often reported (e.g. Bryars et al., 2011; Cabaco et al., 2008; Hughes et al., 2004), sometimes accompanied by reductions in seagrass growth, biomass, and/or shoot density under increased epiphyte loads (Blake and Duffy 2012; Bryars et al., 2011; reviewed by Burkholder et al., 2007; 
reviewed by Cabaco et al., 2013; Clausen et al., 2014; Hughes et al., 2004). However, in this study, epiphyte biomass did not respond consistently to nutrient addition (Chapter 3 ). The positive relationship between epiphyte biomass and number of blades in the Elsdon trial (Chapter 3 ) indicates that either the number of blades per container increased in response to light reduction from increased epiphyte biomass, or more likely that more blades provide a greater surface area for colonisation. Taken together, these results suggest that bottomup processes did not have a strong role on seagrass growth and performance. These results are supported by other studies that have likewise found no effect of nutrients on epiphyte loads (Armitage and Fourqurean, 2006; Campbell and Fourqurean, 2014), or epiphyte loads on seagrass characteristics (Cook et al., 2011; Ebrahim et al., 2014; Gacia et al., 2009; Ruesink, 2016). Furthermore, experiments in the present study demonstrated that seagrass from both Browns Bay and Elsdon can withstand epiphyte loads over 100 times greater than those recorded during field surveys. However, water clarity may have been higher in the laboratory than field, allowing greater solar radiation to heavily epiphytised blades.

Seagrass meadows with higher genetic variation and high grazer species richness in the Northern Hemisphere have been linked to stronger top-down control of epiphytes than in concurrent nutrient/grazer manipulations using genetically similar seagrass (Duffy et al., 2015). As discussed in Chapter 3 , the genetic variation of seagrass from the Porirua Harbour is unknown. Campanella et al. (2013) reported high levels of inbreeding in the seagrass of Barnegat Bay (New Jersey) which had declined by $62 \%$ over 20 years (compared to $\sim 40 \%$ declines over 50 to 60 years in the Porirua Harbour (Matheson and Wadha, 2012)). Though the decline at Barnegat Bay was more rapid, inbreeding may also have occurred within the Porirua Harbour. The distinct North- and South- Island populations, as well as East and West coast populations within each identified by Jones et al. (2008) suggests that seagrass within the Porirua Harbour will share few genetic traits with the better-studied northern meadows (Tauranga, Whangapoua, Whangarei, Whangamata). These genetic differences may play a role in the differing seagrass characteristics between the Northern meadows and those of the Porirua Harbour (see Chapter 2 Discussion), although the abiotic conditions (particularly warmer northern temperatures) are also likely to play a role (Clausen et al., 2014). Research into the genetics of the seagrass within Porirua Harbour would be 
beneficial in management decisions, as well as elucidating possible reasons for differences between meadows.

In this study, seagrass characteristics varied across three nearby $(<4 \mathrm{~km})$ sites with differing abiotic and biotic conditions (Chapter 2). Furthermore, seagrass from the enriched Elsdon site was less sensitive to increased nutrient loads than seagrass from the un-enriched Browns Bay (Chapter 3). This indicates that prior exposure of seagrass to particular environmental variables may reduce our ability to make comparisons to other meadows. As concluded by Bulmer et al. (2016), previously established physiological limits provide useful information, but data on each site is far more informative for management. Wellington Regional Council and Porirua City Council consider the restoration and health of seagrass within the Porirua Harbour a priority, with ongoing monitoring across the harbour, efforts to improve water quality and transplantation of seagrass to areas of historic seagrass cover.

\section{Limitations of Research}

The main limitations of this thesis come down to time and resource constraints. Time constraints meant that there were only two sampling periods (Chapter 2), and experiments could only last for three weeks (Chapter 3). Further, experiments for seagrass obtained from both sites were unable to be completed at the same time (Chapter 3). Recent data on the seagrass of the Porirua Harbour is available for summer and winter only, with no data on trends in spring or autumn. Temporal release from stressors, such as UV, temperature extremes, light limitation, and fresh water input would be expected to differ most between summer and winter, but trends in other seasons may also be important. Furthermore, short term experiments tend to see the immediate effects of nutrient enrichment (increased algal biomass, increased growth, etc.), where longer term (usually field-based) experiments reveal a more realistic response (Cabaço et al., 2013; Irlandi et al., 2004). For example, a recent Australian study demonstrated that increased nutrient concentrations caused a "slow decline" in both Amphibolis antarctica and Posidonia sinuosa over 15 months, with up to $50 \%$ decrease in shoot densities, and up to $30 \%$ decrease in above-ground biomass (Bryars et al., 2011). There is evidence that changes to meadows in response to high nutrient loads can continue far beyond the nutrient event (Bryars et al., 2011; Kennish et al., 2016; van Katwijk et al., 2010). 
Neither field surveys nor laboratory experiments accounted for the influences of tidal movement, predators, or conspecifics/competitors on micro-grazers. While Z. muelleri can photosynthesise at maximum rates when exposed at low tide, sufficiently clear water allows these maximal rates as well (Schwarz, 2004). Tidal influence is therefore unlikely to have altered seagrass response. However, gastropods are mobile, so can reduce exposure to stressors, competition and predation by changing their behaviour. For example, one behaviour may be used to reduce predation risk from aquatic predators, while another reduces desiccation stress while the tide is out (and aquatic predators are therefore less of a threat).

Seagrass reduces predation pressure on infauna from generalist (i.e. non-specialised) predators (Cardoso et al., 2002; Jorgensen et al., 2007; McCloskey and Unsworth, 2015), but not ambush predators which prefer seagrass habitats (Schultz et al., 2009). Predator presence also alters the behaviour of grazers, such as the increased grazing rates by micrograzers when predators were excluded by Armitage and Fourqurean (2006). Furthermore, Edgar (1990) concluded that these communities are largely determined by diffuse exploitative competition, where a shared food source (e.g. epiphytic algae) is limiting. Such competition can lead to reduced habitat quality or niche partitioning (Best and Stachowicz, 2014; McCloskey and Unsworth, 2015), which was not accounted for here.

\section{Conclusions and Suggestions for Further Research}

This thesis has contributed information on the spatial and temporal variation of seagrass and its associated gastropod grazers and epiphytic algae. The adaptation of Elsdon seagrass to very high nutrient levels indicates either genetic differences between this and the seagrass of Browns Bay, or high phenotypic plasticity. The differing responses of the seagrasses of Browns Bay and Elsdon to experimental nutrient addition demonstrates the necessity of monitoring and management efforts that focus on sites, rather than the harbour as a whole. Micro-grazers were demonstrated to play a limited role in epiphyte control, with field surveys indicating a level of control, but experiments failing to confirm this. Little research exists on the seagrass-associated fauna of New Zealand harbours. Further research into the roles of gastropod and crustacean grazers in seagrass meadows, and how those roles change under multiple stressors (e.g. wave action, temperature, salinity, etc.) is required to better understand how they influence system dynamics. Ideally, 
this would involve incorporating field and laboratory experiments, in order to test the roles over multiple spatial and time scales, as well as account for in situ processes that cannot be replicated in the laboratory. 


\section{$\underline{\text { References }}$}

Abal, E.; Loneragan, N.; Bowen, P.; Perry, C.; Udy, J.; Dennison, W. 1994. Physiological and morphological responses of the seagrass Zostera capricorni Aschers, to light intensity. Journal of Experimental Marine Biology and Ecology 178: 113-129.

Ahrens, M.J.; Hickey, C.W. 2002. UV-photoactivation of polycyclic aromatic hydrocarbons and the sensitivity of sediment-dwelling estuarine organisms. UV radiation and its effects: an update 2002. Proceedings of a workshop held in Christchurch. RSNZ miscellaneous series, pp 63-65.

Alexandre, A.; Silva, J.; Santos, R. 2016. Nitrogen uptake in light versus darkness of the seagrass Zostera noltei: integration with carbon metabolism. Marine Ecology-an Evolutionary Perspective 37: 1050-1056.

Alfaro, A.C. 2006a. Benthic macro-invertebrate community composition within a mangrove/seagrass estuary in northern New Zealand. Estuarine, Coastal and Shelf Science 66: 97-110.

Alfaro, A.C. 2006b. Tidal migration influences the zonation of grazing snails (Turbo smaragdus) in a mangrove-seagrass estuary, northern New Zealand. Estuaries and Coasts 29: 731-736.

Alfaro, A.C.; Thomas, F.; Sergent, L.; Duxbury, M. 2006. Identification of trophic interactions within an estuarine food web (northern New Zealand) using fatty acid biomarkers and stable isotopes. Estuarine Coastal and Shelf Science 70: 271-286.

Almeida, C.; Coelho, R.; Silva, M.; Bentes, L.; Monteiro, P.; Ribeiro, J.; Erzini, K.; Goncalves, J.M.S. 2008. Use of different intertidal habitats by faunal communities in a temperate coastal lagoon. Estuarine Coastal and Shelf Science 80: 357-364.

Anscombe, F.J. 1953. Sequential estimation. Journal of the Royal Statistical Society. Series $B$ (Methodological) 15: 1-29.

Armitage, A.R.; Fourqurean, J.W. 2006. The short-term influence of herbivory near patch reefs varies between seagrass species. Journal of Experimental Marine Biology and Ecology 339: 65-74.

Armitage, A.R.; Frankovich, T.A.; Heck, K.L.; Fourqurean, J.W. 2005. Experimental nutrient enrichment causes complex changes in seagrass, microalgae, and macroalgae community structure in Florida Bay. Estuaries 28: 422-434.

Arrontes, J.; Arenas, F.; Fernandez, C.; Rico, J.M.; Oliveros, J.; Martinez, B.; Viejo, R.M.; Alvarez, D. 2004. Effect of grazing by limpets on mid-shore species assemblages in northern Spain. Marine Ecology Progress Series 277: 117-133.

Attrill, M.J.; Strong, J.A.; Rowden, A.A. 2000. Are macroinvertebrate communities influenced by seagrass structural complexity? Ecography 23: 114-121. 
Azevedo, A.; Dias, J.M.; Lillebo, A.I. 2016. Thriving of Zostera noltei under intertidal conditions: Implications for the modelling of seagrass populations. Marine Biology 163: 1-8.

Batiuk, R.; Orth, R.; Moore, K.; Dennison, W.; Stevenson, J. 1992. Chesapeake Bay submerged aquatic vegetation habitat requirements and restoration targets: $A$ technical synthesis. Virginia Inst. of Marine Science, Gloucester Point, VA (United States).

Battley, P.F.; Melville, D.S.; Schuckard, R.; Ballance, P.F. 2011. Zostera muelleri as a structuring agent of benthic communities in a large intertidal sandflat in New Zealand. Journal of Sea Research 65: 19-27.

Benedetti-Cecchi, L.; Bulleri, F.; Cinelli, F. 2000. The interplay of physical and biological factors in maintaining mid-shore and low-shore assemblages on rocky coasts in the northwest Mediterranean. Oecologia 123: 406-417.

Best, R.J.; Stachowicz, J.J. 2014. Phenotypic and phylogenetic evidence for the role of food and habitat in the assembly of communities of marine amphipods. Ecology 95: 775-786.

Bishop, M.J.; Kelaher, B.P.; Sharp, S.M.; Verhoeven, M. 2007. Dispersal of the estuarine gastropod Pyrazus ebeninus is only weakly influenced by pneumatophore density. Journal of Experimental Marine Biology and Ecology 340: 62-69.

Blake, R.E.; Duffy, J.E. 2010. Grazer diversity affects resistance to multiple stressors in an experimental seagrass ecosystem. Oikos 119: 1625-1635.

Blake, R.E.; Duffy, J.E. 2012. Changes in biodiversity and environmental stressors influence community structure of an experimental eelgrass Zostera marina system. Marine Ecology Progress Series 470: 41-54.

Blanchet, H.; de Montaudouin, X.; Lucas, A.; Chardy, P. 2004. Heterogeneity of macrozoobenthic assemblages within a Zostera noltii seagrass bed: diversity, abundance, biomass and structuring factors. Estuarine, Coastal and Shelf Science 61: 111-123.

Bloomfield, A.L.; Gillanders, B.M. 2005. Fish and invertebrate assemblages in seagrass, mangrove, saltmarsh, and nonvegetated habitats. Estuaries 28: 63-77.

Boese, B.L.; Alayan, K.E.; Gooch, E.F.; Robbins, B.D. 2003. Desiccation index: a measure of damage caused by adverse aerial exposure on intertidal eelgrass (Zostera marina) in an Oregon (USA) estuary. Aquatic Botany 76: 329-337.

Borowitzka, M.A.; Lethbridge, R.C.; Charlton, L. 1990. Species richness, spatial distribution and colonisation pattern of algal and invertebrate epiphytes on the seagrass Amphibolis griffithii. Marine Ecology Progress Series 64: 281-291.

Bourque, A.S.; Fourqurean, J.W. 2014. Effects of common seagrass restoration methods on ecosystem structure in subtropical seagrass meadows. Marine Environmental Research 97: 67-78.

Brenchley, G.A. 1982. Mechanisms of spatial competition in marine soft-bottom communities. Journal of Experimental Marine Biology and Ecology 60: 17-33. 
Bryan, K.R.; Tay, H.W.; Pilditch, C.A.; Lundquist, C.J.; Hunt, H.L. 2007. The effects of seagrass (Zostera muelleri) on boundary-layer hydrodynamics in Whangapoua Estuary, New Zealand. Journal of Coastal Research: 50, 668-672.

Bryars, S.; Collings, G.; Miller, D. 2011. Nutrient exposure causes epiphytic changes and coincident declines in two temperate Australian seagrasses. Marine Ecology Progress Series 441: 89-103.

Bulmer, R.H.; Kelly, S.; Jeffs, A.G. 2016. Light requirements of the seagrass, Zostera muelleri, determined by observations at the maximum depth limit in a temperate estuary, New Zealand. New Zealand Journal of Marine and Freshwater Research 50: 183-194.

Bulthuis, D.A. 1987. Effects of temperature on photosynthesis and growth of seagrasses. Aquatic Botany 27: 27-40.

Burkholder, J.; Glasgow, H.; Cooke, J. 1994. Comparative effects of water-column nitrate enrichment on eelgrass Zostera marina, shoalgrass Halodule wrightii, and widgeongrass Ruppia maritima. Marine Ecology Progress Series 105: 121-138.

Burkholder, J.M.; Tomasko, D.A.; Touchette, B.W. 2007. Seagrasses and eutrophication. Journal of Experimental Marine Biology and Ecology 350: 46-72.

Cabaço, S.; Apostolaki, E.T.; García-Marín, P.; Gruber, R.; Hernandez, I.; Martínez-Crego, B.; Mascaro, O.; Perez, M.; Prathep, A.; Robinson, C. 2013. Effects of nutrient enrichment on seagrass population dynamics: evidence and synthesis from the biomass-density relationships. Journal of Ecology 101: 1552-1562.

Cabaco, S.; Santos, R. 2012. Seagrass reproductive effort as an ecological indicator of disturbance. Ecological Indicators 23: 116-122.

Cabaço, S.; Machás, R.; Vieira, V.; Santos, R. 2008. Impacts of urban wastewater discharge on seagrass meadows (Zostera noltii). Estuarine, Coastal and Shelf Science 78: 1-13.

Campanella, J.J.; Bologna, P.A.X.; Smalley, J.V.; Avila, D.N.; Lee, K.N.; Areche, E.C.; Slavin, L.J. 2013. An analysis of the population genetics of restored Zostera marina plantings in Barnegat Bay, New Jersey. Population Ecology 55: 121-133.

Campbell, J.E.; Fourqurean, J.W. 2014. Ocean acidification outweighs nutrient effects in structuring seagrass epiphyte communities. Journal of Ecology 102: 730-737.

Cardoso, P.G.; Lillebo, A.I.; Pardal, M.A.; Ferreira, S.M.; Marques, J.C. 2002. The effect of different primary producers on Hydrobia ulvae population dynamics: a case study in a temperate intertidal estuary. Journal of Experimental Marine Biology and Ecology 277: 173195.

Cardoso, P.G.; Pardal, M.A.; Lillebo, A.I.; Ferreira, S.M.; Raffaelli, D.; Marques, J.C. 2004. Dynamic changes in seagrass assemblages under eutrophication and implications for recovery. Journal of Experimental Marine Biology and Ecology 302: 233-248. 
Carr, L.A.; Boyer, K.E. 2014. Variation at multiple trophic levels mediates a novel seagrassgrazer interaction. Marine Ecology Progress Series 508: 117-128.

Carstensen, J.; Krause-Jensen, D.; Balsby, T.J.S. 2016. Biomass-cover relationship for eelgrass meadows. Estuaries and Coasts 39: 440-450.

Christianen, M.J.A.; Govers, L.L.; Bouma, T.J.; Kiswara, W.; Roelofs, J.G.M.; Lamers, L.P.M.; van Katwijk, M.M. 2012. Marine megaherbivore grazing may increase seagrass tolerance to high nutrient loads. Journal of Ecology 100: 546-560.

Clausen, K.K.; Krause-Jensen, D.; Olesen, B.; Marbà, N. 2014. Seasonality of eelgrass biomass across gradients in temperature and latitude. Marine Ecology Progress Series 506: 71-85.

Connell, J.H. 1972. Community interactions on marine rocky intertidal shores. Annual Review of Ecology and Systematics 3: 169-192.

Connolly, R.M. 1994. A comparison of fish assemblages from seagrass and unvegetated areas of a Southern Australian estuary. Australian Journal of Marine and Freshwater Research 45: 1033-1044.

Cook, K.; Vanderklift, M.A.; Poore, A.G.B. 2011. Strong effects of herbivorous amphipods on epiphyte biomass in a temperate seagrass meadow. Marine Ecology Progress Series 442: 263-269.

Creed, J.C. 1997. Morphological variation in the seagrass Halodule wrightii near its southern distributional limit. Aquatic Botany 59: 163-172.

Crowe, T. 1996. Different effects of microhabitat fragmentation on patterns of dispersal of an intertidal gastropod in two habitats. Journal of Experimental Marine Biology and Ecology 206: 83-107.

Daudi, L.N.; Lugomela, C.; Uku, J.N.; De Troch, M. 2012. Effect of nutrient enrichment on seagrass associated meiofauna in Tanzania. Marine Environmental Research 82: 49-58.

De Angelo, J.A.; Stevens, P.W.; Blewett, D.A.; Switzer, T.S. 2014. Fish assemblages of shoaland shoreline-associated seagrass beds in eastern Gulf of Mexico estuaries. Transactions of the American Fisheries Society 143: 1037-1048.

Deegan, L.A.; Wright, A.; Ayvazian, S.G.; Finn, J.T.; Golden, H.; Merson, R.R.; Harrison, J. 2002. Nitrogen loading alters seagrass ecosystem structure and support of higher trophic levels. Aquatic Conservation-Marine and Freshwater Ecosystems 12: 193-212.

Dennison, W.C.; Orth, R.J.; Moore, K.A.; Stevenson, J.C.; Carter, V.; Kollar, S.; Bergstrom, P.W.; Batiuk, R.A. 1993. Assessing water quality with submersed aquatic vegetation. Bioscience 43: 86-94.

Dolbeth, M.; Pardal, M.; Lilleb $\varnothing$, A.; Azeiteiro, U.; Marques, J. 2003. Short-and long-term effects of eutrophication on the secondary production of an intertidal macrobenthic community. Marine Biology 143: 1229-1238. 
Dos Santos, V.M.; Matheson, F.E.; Pilditch, C.A.; Elger, A. 2012. Is black swan grazing a threat to seagrass? Indications from an observational study in New Zealand. Aquatic Botany 100: 41-50.

Dos Santos, V.M.; Matheson, F.E.; Pilditch, C.A.; Elger, A. 2013. Seagrass resilience to waterfowl grazing in a temperate estuary: A multi-site experimental study. Journal of Experimental Marine Biology and Ecology 446: 194-201.

Douglass, J.G.; Duffy, J.E.; Canuel, E.A. 2011. Food Web Structure in a Chesapeake Bay Eelgrass bed as determined through gut contents and $\mathrm{C}-13$ and $\mathrm{N}-15$ isotope analysis. Estuaries and Coasts 34: 701-711.

Duarte, C.M. 1991. Allometric scaling of seagrass form and productivity. Marine Ecology Progress Series 77: 289-300.

Duarte, C.M. 2002. The future of seagrass meadows. Environmental Conservation 29: 192206.

Duffy, J.E. 2006. Biodiversity and the functioning of seagrass ecosystems. Marine Ecology Progress Series 311: 233-250.

Duffy, J.E.; Reynolds, P.L.; Boström, C.; Coyer, J.A.; Cusson, M.; Donadi, S.; Douglass, J.G.; Eklöf, J.S.; Engelen, A.H.; Eriksson, B.K. 2015. Biodiversity mediates top-down control in eelgrass ecosystems: a global comparative-experimental approach. Ecology Letters 18: 696705.

Duffy, J.E.; Richardson, J.P.; Canuel, E.A. 2003. Grazer diversity effects on ecosystem functioning in seagrass beds. Ecology Letters 6: 637-645.

Duncan, A. 2015. Seagrass Condition in Te Awarua-o-Porirua Harbour. Report prepared for VUW Summer Scholarship Programme 2014/15. (referenced in Milne J. and Oliver M. 2015. Te Awarua-O Porirua Harbour and catchment - science update. (Report PCC 1103574.)).

Ebrahim, A.; Olds, A.D.; Maxwell, P.S.; Pitt, K.A.; Burfeind, D.D.; Connolly, R.M. 2014. Herbivory in a subtropical seagrass ecosystem: separating the functional role of different grazers. Marine Ecology Progress Series 511: 83-91.

Edgar, G.J. 1990. Population regulation, population dynamics and competition amongst mobile epifauna associated with seagrass. Journal of Experimental Marine Biology and Ecology 144: 205-234.

Eldridge, P.M.; Morse, J.W. 2000. A diagenetic model for sediment-seagrass interactions. Marine Chemistry 70: 89-103.

Enríquez, S.; Agusti, S.; Duarte, C. 1992. Light absorption by seagrass Posidonia oceanica leaves. Marine Ecology Progress Series 86: 201-204

Farina, S.; Tomas, F.; Prado, P.; Romero, J.; Alcoverro, T. 2009. Seagrass meadow structure alters interactions between the sea urchin Paracentrotus lividus and its predators. Marine Ecology Progress Series 377: 131-137. 
Fawcett, M.H. 1984. Local and latitudinal variation in predation on an herbivorous marine snail. Ecology 65: 1214-1230.

Fish, J.; Fish, S. 1974. The breeding cycle and growth of Hydrobia ulvae in the Dovey estuary. Journal of the Marine Biological Association of the United Kingdom 54: 685-697.

Flaherty, K.E.; Switzer, T.S.; Winner, B.L.; Keenan, S.F. 2014. Regional Correspondence in Habitat Occupancy by Gray Snapper (Lutjanus griseus) in Estuaries of the Southeastern United States. Estuaries and Coasts 37: 206-228.

Gacia, E.; Costalago, D.; Prado, P.; Piorno, D.; Tomas, F. 2009. Mesograzers in Posidonia oceanica meadows: an update of data on gastropod-epiphyte-seagrass interactions. Botanica Marina 52: 439-447.

Gacia, E.; Duarte, C.M. 2001. Sediment retention by a Mediterranean Posidonia oceanica meadow: the balance between deposition and resuspension. Estuarine, Coastal and Shelf Science 52: 505-514.

Gartner, A.; Lavery, P.S.; McMahon, K.; Brearley, A.; Barwick, H. 2010. Light reductions drive macroinvertebrate changes in Amphibolis griffithii seagrass habitat. Marine Ecology Progress Series 401: 87-100.

Gobert, S.; Cambridge, M.T.; Velimirov, B.; Pergent, G.; Lepoint, G.; Bouquegneau, J.-M.; Dauby, P.; Pergent-Martini, C.; Walker, D.I. 2007. Biology of Posidonia. Seagrasses: Biology, Ecology and Conservation, pp 387-408. Springer.

Green, E.P.; Short, F.T. 2003. World atlas of seagrasses. Univ of California Press.

Greve, T.M.; Binzer, T. 2004. Which factors regulate seagrass growth and distribution. European seagrasses: an introduction to monitoring and management. Monitoring and Managing of European Seagrasses Project (M\&MS): 19-23.

Harrell JR, F.E. and with contributions from Charles Dupont and many others. 2016. Hmisc: Harrell Miscellaneous. R package version 4.0-2. https://CRAN.R-project.org/package=Hmisc.

Hasegawa, N.; Hori, M.; Mukai, H. 2007. Seasonal shifts in seagrass bed primary producers in a cold-temperate estuary: Dynamics of eelgrass Zostera marina and associated epiphytic algae. Aquatic Botany 86: 337-345.

Hasegawa, N.; Hori, M.; Mukai, H. 2008. Seasonal changes in eelgrass functions: current velocity reduction, prevention of sediment resuspension, and control of sediment-water column nutrient flux in relation to eelgrass dynamics. Hydrobiologia 596: 387-399.

Hauxwell, J.; Cebrián, J.; Furlong, C.; Valiela, I. 2001. Macroalgal canopies contribute to eelgrass (Zostera marina) decline in temperate estuarine ecosystems. Ecology 82: 10071022.

Hay, M.E.; Parker, J.D.; Burkepile, D.E.; Caudill, C.C.; Wilson, A.E.; Hallinan, Z.P.; Chequer, A.D. 2004. Mutualisms and aquatic community structure: The enemy of my enemy is my friend. Annual Review of Ecology Evolution and Systematics 35: 175-197. 
Heck, K.L.; Able, K.W.; Roman, C.T.; Fahay, M.P. 1995. Composition, abundance, biomass and production of macrofauna in a New-England estuary - comparisons among eelgrass meadows and other nursery habitats. Estuaries 18: 379-389.

Heck, K.L.; Hays, G.; Orth, R.J. 2003. Critical evaluation of the nursery role hypothesis for seagrass meadows. Marine Ecology Progress Series 253: 123-136.

Heck, K.L., Jr.; Valentine, J.F. 2007. The primacy of top-down effects in shallow benthic ecosystems. Estuaries and Coasts 30: 371-381.

Heck, K.L.; Valentine, J.F. 2006. Plant-herbivore interactions in seagrass meadows. Journal of Experimental Marine Biology and Ecology 330: 420-436.

Hily, C.; Connan, S.; Raffin, C.; Wyllie-Echeverria, S. 2004. In vitro experimental assessment of the grazing pressure of two gastropods on Zostera marina L. ephiphytic algae. Aquatic Botany 78: 183-195.

Holzer, K.K.; Rueda, J.L.; McGlathery, K.J. 2011. Differences in the feeding ecology of two seagrass-associated snails. Estuaries and Coasts 34: 1140-1149.

Hothorn, T.; Bretz, F.; Westfall, P. 2008. Simultaneous inference in general parametric models. Biometrical Journal 50: 346-363.

Hovey, R.K.; Cambridge, M.L.; Kendrick, G.A. 2012. Season and sediment nutrient additions affect root architecture in the temperate seagrasses $\underline{\text { Posidonia australis and } \underline{P} \text {. sinuosa. }}$ Marine Ecology Progress Series 446: 23-30.

Hughes, A.R.; Bando, K.J.; Rodriguez, L.F.; Williams, S.L. 2004. Relative effects of grazers and nutrients on seagrasses: a meta-analysis approach. Marine Ecology Progress Series 282: 8799.

Irlandi, E.A.; Orlando, B.A.; Cropper, W.P., Jr. 2004. Short-term effects of nutrient addition on growth and biomass of Thalassia testudinum in Biscayne Bay, FL. Florida Scientist 67: 1826.

Jenkins, S.; Coleman, R.; Della Santina, P.; Hawkins, S.; Burrows, M.; Hartnoll, R. 2005. Regional scale differences in the determinism of grazing effects in the rocky intertidal. Marine Ecology Progress Series 287: 77-86.

Jeong, S.J.; Suh, H.L.; Kang, C.K. 2012. Trophic diversity in amphipods within a temperate eelgrass ecosystem as determined by gut contents and $\mathrm{C}$ and $\mathrm{N}$ isotope analysis. Marine Biology 159: 1943-1954.

Jernakoff, P.; Nielsen, J. 1997. The relative importance of amphipod and gastropod grazers in Posidonia sinuosa meadows. Aquatic Botany 56: 183-202.

Jones, N. 1946. Browsing of Patella. Nature 158: 557-558.

Jones, T.C.; Gemmill, C.E.C.; Pilditch, C.A. 2008. Genetic variability of New Zealand seagrass (Zostera muelleri) assessed at multiple spatial scales. Aquatic Botany 88: 39-46. 
Jorgensen, P.; Ibarra-Obando, S.E.; Carriquiry, J.D. 2007. Top-down and bottom-up stabilizing mechanisms in eelgrass meadows differentially affected by coastal upwelling. Marine Ecology Progress Series 333: 81-93.

Kaewsrikhaw, R.; Ritchie, R.J.; Prathep, A. 2016. Variations of tidal exposures and seasons on growth, morphology, anatomy and physiology of the seagrass Halophila ovalis (R.Br.) Hook. f. in a seagrass bed in Trang Province, Southern Thailand. Aquatic Botany 130: 11-20.

Kaldy, J.E.; Fowler, N.; Dunton, K.H. 1999. Critical assessment of Thalassia testudinum (turtle grass) aging techniques: implications for demographic inferences. Marine Ecology Progress Series 181: 279-288.

Kennish, M.J.; Sakowicz, G.P.; Fertig, B. 2016. Recent trends of Zostera marina (eelgrass) in a highly eutrophic coastal lagoon in the mid-Atlantic region (USA). Open Journal of Ecology 6: 243-253.

Kerr, E.A.; Strother, S. 1989. Seasonal changes in leaf growth rate of Zostera muelleri Irmisch ex Aschers. In South-Eastern Australia. Aquatic Botany 33: 131-140.

Kerr, E.A.; Strother, S. 1990. Seasonal-changes in standing crop of Zostera muelleri in SouthEastern Australia. Aquatic Botany 38: 369-376.

Kharlamenko, V.I.; Kiyashko, S.I.; Imbs, A.B.; Vyshkvartzev, D.I. 2001. Identification of food sources of invertebrates from the seagrass Zostera marina community using carbon and sulfur stable isotope ratio and fatty acid analyses. Marine Ecology Progress Series 220: 103117.

Kim, Y.K.; Kim, J.-H.; Kim, S.H.; Kim, J.W.; Park, S.R.; Lee, K.-S. 2012. Growth dynamics of the seagrass, Zostera marina in Jindong Bay on the southern coast of Korea. Algae 27: 215-224.

Kim, J.B.; Lee, W.-C.; Lee, K.-S.; Park, J.-I. 2013. Growth dynamics of eelgrass, Zostera marina, in the intertidal zone of Seomjin Estuary, Korea. Ocean Science Journal 48: 239-250.

Kohlmeier, D.; Pilditch, C.A.; Bornman, J.F.; Bischof, K. 2014. Site specific differences in morphometry and photophysiology in intertidal Zostera muelleri meadows. Aquatic Botany 116: 104-109.

Kowalski, J.L.; DeYoe, H.R.; Allison, T.C.; Kaldy, J.E. 2001. Productivity estimation in Halodule wrightii Aschers: comparison of leaf-clipping and leaf-marking techniques and the importance of clip height. Marine Ecology Progress Series 220: 131-136.

Leduc, D.; Probert, P.K.; Frew, R.D.; Hurd, C.L. 2006. Macroinvertebrate diet in intertidal seagrass and sandflat communities: a study using $\mathrm{C}, \mathrm{N}$, and $\mathrm{S}$ stable isotopes. New Zealand Journal of Marine and Freshwater Research 40: 615-629.

Leduc, D.; Probert, P.; Duncan, A. 2009. A multi-method approach for identifying meiofaunal trophic connections. Marine Ecology Progress Series 383: 95-111. 
Leduc, D.; Probert, P.K. 2011. Small-scale effect of intertidal seagrass (Zostera muelleri) on meiofaunal abundance, biomass, and nematode community structure. Journal of the Marine Biological Association of the United Kingdom 91: 579-591.

Leopardas, V.; Honda, K.; Go, G.A.; Bolisay, K.; Pantallano, A.D.; Uy, W.; Fortes, M.; Nakaoka, M. 2016. Variation in macrofaunal communities of seagrass beds along a pollution gradient in Bolinao, northwestern Philippines. Marine Pollution Bulletin 105: 310-318.

Les, D.H.; Moody, M.L.; Jacobs, S.W.; Bayer, R.J. 2002. Systematics of seagrasses (Zosteraceae) in Australia and New Zealand. Systematic Botany 27: 468-484.

Lillebo, A.I.; Pardal, M.A.; Marques, J.C. 1999. Population structure, dynamics and production of Hydrobia ulvae (Pennant) (Mollusca : Prosobranchia) along an eutrophication gradient in the Mondego estuary (Portugal). Acta Oecologica-International Journal of Ecology 20: 289-304.

Malaquias, M.A.E.; Sprung, M.J. 2005. Population biology of the cephalaspidean mollusc Haminoea orbygniana in a temperate coastal lagoon (Ria Formosa, Portugal). Estuarine, Coastal and Shelf Science 63: 177-185.

Matheson, F.; Reed, J.; Dos Santos, V.M.; Cummings, V.J.; MacKay, G.; Jordan, M. 2009. Seagrass restoration in Whangarei Harbour: Results of a small-scale transplantation trial. NIWA Consultancy Report for Northland Regional Council HAM2008-063, 25 p.

Matheson, F.; Wadha, S. 2012. Seagrass in the Porirua Harbour. Preliminary Assessment of Restoration Potential. Prepared for the Greater Wellington Regional Council. Retrieved from http://www.gw.govt.nz/assets/Seagrass-restoration-in-Porirua-Harbour.pdf.

Matheson, F.E.; Schwarz, A.M. 2007. Growth responses of Zostera capricorni to estuarine sediment conditions. Aquatic Botany 87: 299-306.

McCloskey, R.M.; Unsworth, R.K. 2015. Decreasing seagrass density negatively influences associated fauna. PeerJ 3: e1053.

McMahon, R.F. 1990. Thermal tolerance, evaporative water-loss, air-water oxygenconsumption and zonation of intertidal prosobranchs - a new synthesis. Hydrobiologia 193: 241-260.

McSkimming, C.; Tanner, J.E.; Russell, B.D.; Connell, S.D. 2015. Compensation of nutrient pollution by herbivores in seagrass meadows. Journal of Experimental Marine Biology and Ecology 471: 112-118.

McSkimming, C.; Connell, S.D.; Russell, B.D.; Tanner, J.E. 2016. Habitat restoration: Early signs and extent of faunal recovery relative to seagrass recovery. Estuarine Coastal and Shelf Science 171: 51-57.

Miller, A.A.; Poulin, R. 2001. Parasitism, movement, and distribution of the snail Diloma subrostrata (Trochidae) in a soft-sediment intertidal zone. Canadian Journal of Zoology 79: 2029-2035. 
Miller, C.J.; Campbell, S.J.; Scudds, S. 2005. Spatial variation of Zostera tasmanica morphology and structure across an environmental gradient. Marine Ecology Progress Series 304: 45-53.

Mills, V.S.; Berkenbusch, K. 2009. Seagrass (Zostera muelleri) patch size and spatial location influence infaunal macroinvertebrate assemblages. Estuarine Coastal and Shelf Science 81: 123-129.

Moore, K.A.; Short, F.T. 2007. Zostera: Biology, ecology, and management. Seagrasses: Biology, Ecology and Conservation, pp 361-386. Springer.

Moore, K.A.; Wetzel, R.L. 2000. Seasonal variations in eelgrass (Zostera marina L.) responses to nutrient enrichment and reduced light availability in experimental ecosystems. Journal of Experimental Marine Biology and Ecology 244: 1-28.

Morelissen, B. 2012. Ecological effects of Undaria pinnatifida (Harvey) Suringar and nutrientenrichment on intertidal assemblages in the Wellington region of New Zealand. School of Biological Sciences. Victoria University of Wellington, Wellington, New Zealand.

Morrison, M.; Francis, M.; Hartill, B.; Parkinson, D. 2002. Diurnal and tidal variation in the abundance of the fish fauna of a temperate tidal mudflat. Estuarine, Coastal and Shelf Science 54: 793-807.

Nakano, T.; Spencer, H.G. 2007. Simultaneous polyphenism and cryptic species in an intertidal limpet from New Zealand. Molecular Phylogenetics and Evolution 45: 470-479.

Nakano, T.; Marshall, B.A.; Kennedy, M.; Spencer, H.G. 2009. The phylogeny and taxonomy of New Zealand Notoacmea and Patelloida species (Mollusca: Patellogastropoda: Lottiidae) inferred from DNA sequences. Molluscan Research 29: 33.

Nelson, T.A.; Waaland, J.R. 1997. Seasonality of eelgrass, epiphyte, and grazer biomass and productivity in subtidal eelgrass meadows subjected to moderate tidal amplitude. Aquatic Botany 56: 51-74.

Norberg, J. 2000. Resource-niche complementarity and autotrophic compensation determines ecosystem-level responses to increased Cladoceran species richness. Oecologia 122: 264-272.

Ollivier, Q.R.; Bramwell, N.A.; Hammill, E.; Foster-Thorpe, C.; Booth, D.J. 2015. Are the effects of adjacent habitat type on seagrass gastropod communities being masked by previous focus on habitat dyads? Australian Journal of Zoology 63: 357-363.

Olsen, Y.S.; Fox, S.E.; Teichberg, M.; Otter, M.; Valiela, I. 2011. $\delta 15 \mathrm{~N}$ and $\delta 13 \mathrm{C}$ reveal differences in carbon flow through estuarine benthic food webs in response to the relative availability of macroalgae and eelgrass. Marine Ecology Progress Series 421: 83-96.

Orth, R.J.; Van Montfrans, J. 1984. Epiphyte-seagrass relationships with an emphasis on the role of micrograzing: a review. Aquatic Botany 18: 43-69. 
Orvain, F.; Sauriau, P.-G. 2002. Environmental and behavioural factors affecting activity in the intertidal gastropod Hydrobia ulvae. Journal of Experimental Marine Biology and Ecology 272: 191-216.

Ott, J.A. 1980. Growth and production in Posidonia oceanica (L.) Delile. Marine Ecology 1: 47-64.

Paavo, B.L.; Ham, D.; Gorlitz, S.; Probert, P.K. 2012. How does tidal submersion time affect macroinvertebrate community patterns on a temperate sheltered sandflat? Marine and Freshwater Research 63: 68-77.

Park, S. 2011. Sea Lettuce and Nutrient Monitoring in Tauranga Harbour 1991-2010. Prepared for Bay of Plenty Regional Council. ISSN: 1179 9471. Retrieved from https://www.boprc.govt.nz.

Park, S. 2016. Extent of seagrass in the Bay of Plenty. Bay of Plenty Regional Council Environmental Publication 2016/03. Whakatane, New Zealand. Retrieved from: www.boprc.govt.nz.

Parsons, D.M.; Morrison, M.A.; Thrush, S.F.; Middleton, C.; Smith, M.; Spong, K.T.; Buckthought, D. 2013. The influence of habitat structure on juvenile fish in a New Zealand estuary. Marine Ecology - an Evolutionary Perspective 34: 492-500.

Parsons, D.M.; Middleton, C.; Smith, M.D.; Cole, R.G. 2014. The influence of habitat availability on juvenile fish abundance in a northeastern New Zealand estuary. New Zealand Journal of Marine and Freshwater Research 48: 216-228.

Parsons, D.M.; Middleton, C.; Spong, K.T.; Mackay, G.; Smith, M.D.; Buckthought, D. 2015. Mechanisms explaining nursery habitat association: how do juvenile snapper (Chrysophrys auratus) benefit from their nursery habitat? Plos One 10: e0122137.

Parsons, D.M.; Buckthought, D.; Middleton, C.; MacKay, G. 2016. Relative abundance of snapper (Chrysophrys auratus) across habitats within an estuarine system. New Zealand Journal of Marine and Freshwater Research 50: 358-370.

Penhale, P.A.; Smith, W.O. 1977. Excretion of dissolved organic carbon by eelgrass (Zostera marina) and its epiphytes. Limnology and Oceanography 22: 400-407.

Peterson, C.H. 1982. Clam predation by whelks (Busycon spp.): Experimental tests of the importance of prey size, prey density, and seagrass cover. Marine Biology 66: 159-170.

Phillips, N.E.; Hutchison, E. 2008. Grazer effects on algal assemblages and mussel recruitment in two different mid-intertidal communities in the Cook Strait, New Zealand. New Zealand Journal of Marine and Freshwater Research 42: 297-306.

Piazzi, L.; Balata, D.; Ceccherelli, G. 2016. Epiphyte assemblages of the Mediterranean seagrass Posidonia oceanica: an overview. Marine Ecology - an Evolutionary Perspective 37: 3-41. 
Poore, A.G.B.; Campbell, A.H.; Steinberg, P.D. 2009. Natural densities of mesograzers fail to limit growth of macroalgae or their epiphytes in a temperate algal bed. Journal of Ecology 97: 164-175.

R-Core-Team. 2016. R: A Language and Environment for Statistical Computing. R Foundation for Statistical Computing, Vienna, Austria. URL https://www.R-project.org/.

Ralph, P.J.; Durako, M.J.; Enriquez, S.; Collier, C.J.; Doblin, M.A. 2007. Impact of light limitation on seagrasses. Journal of Experimental Marine Biology and Ecology 350: 176-193.

Reynolds, L.K.; Carr, L.A.; Boyer, K.E. 2012. A non-native amphipod consumes eelgrass inflorescences in San Francisco Bay. Marine Ecology Progress Series 451: 107-118.

Reynolds, L.K.; Marino, R.; Muth, M.F.; McLenaghan, N.; Hayn, M.; Tyler, A.C.; McGlathery, K.J.; Howarth, R.W. 2015. Evidence of grazer control on nitrogen fixation by eelgrass epiphytes in a temperate coastal bay. Marine Ecology Progress Series 526: 11-19.

Rowden, A.; Berkenbusch, K.; Brewin, P.; Dalen, J.; Neill, K.; Nelson, W.; Oliver, M.; Probert, P.; Schwarz, A.; Sui, P. 2012. A review of the marine soft-sediment assemblages of New Zealand. NZ Aquatic Environment and Biodiversity Report.

RStudio. Team (2015). RStudio: Integrated Development for R. RStudio, Inc., Boston, MA URL http://www.rstudio.com/.

Rubio, L.; Linares-Rueda, A.; García-Sánchez, M.J.; Fernández, J.A. 2007. Ammonium uptake kinetics in root and leaf cells of Zostera marina L. Journal of Experimental Marine Biology and Ecology 352: 271-279.

Ruesink, J.L. 2016. Epiphyte load and seagrass performance are decoupled in an estuary with low eutrophication risk. Journal of Experimental Marine Biology and Ecology 481: 1-8.

Sandoval-Gil, J.M.; Ruiz, J.M.; Marin-Guirao, L.; Bernardeau-Esteller, J.; Sanchez-Lizaso, J.L. 2014. Ecophysiological plasticity of shallow and deep populations of the Mediterranean seagrasses Posidonia oceanica and Cymodocea nodosa in response to hypersaline stress. Marine Environmental Research 95: 39-61.

Schindler, D.E.; Johnson, B.M.; Mackay, N.A.; Bouwes, N.; Kitchell, J.F. 1994. Crab-snail size structured interactions and salt marsh predation gradients. Oecologia 97: 49-61.

Schultz, S.T.; Kruschel, C.; Bakran-Petricioli, T. 2009. Influence of seagrass meadows on predator-prey habitat segregation in an Adriatic lagoon. Marine Ecology Progress Series 374: 85-99.

Schwarz, A.-M.; Morrison, M.; Hawes, I.; Halliday, J. 2006. Physical and biological characteristics of a rare marine habitat: sub-tidal seagrass beds of offshore islands. Science for Conservation (Wellington) 269: 1-39.

Schwarz, A.M. 2004. Contribution of photosynthetic gains during tidal emersion to production of Zostera capricorni in a North Island, New Zealand estuary. New Zealand Journal of Marine and Freshwater Research 38: 809-818. 
Short, F.T.; Wyllie-Echeverria, S. 1996. Natural and human-induced disturbance of seagrasses. Environmental Conservation 23: 17-27.

Skilleter, G.A.; Wegscheidl, C.; Lanyon, J.M. 2007. Effects of grazing by a marine megaherbivore on benthic assemblages in a subtropical seagrass bed. Marine Ecology Progress Series 351: 287-300.

Smyth, A.R.; Thompson, S.P.; Siporin, K.N.; Gardner, W.S.; McCarthy, M.J.; Piehler, M.F. 2013. Assessing nitrogen dynamics throughout the estuarine landscape. Estuaries and Coasts 36: 44-55.

Sola, J.C. 1996. Population dynamics, reproduction, growth, and secondary production of the mud-snail Hydrobia ulvae (Pennant). Journal of Experimental Marine Biology and Ecology 205: 49-62.

Solana-Arellano, E.; Echavarria-Heras, H.; Franco-Vizcaino, E. 2010. A dynamical model for characterising seasonality effects on eelgrass plastochron intervals. Annals of Applied Biology 157: 99-110.

Sprung, M. 1994. Macrobenthic secondary production in the intertidal zone of the Ria Formosa-a lagoon in southern Portugal. Estuarine, Coastal and Shelf Science 38: 539-558.

Stevens, L.; Robertson, B. 2013. Porirua Harbour broad scale habitat mapping 2012/13. Prepared for the Greater Wellington Regional Council. Retrieved from http://www.gw.govt.nz/.

Stevens, L.; Robertson, B. 2014. Porirua Harbour intertidal macroalgal monitoring 2013/14. Prepared for the Greater Wellington Regional Council. Retrieved from http://www.gwrc.govt.nz/.

Stevens, L.; Robertson, B. 2016. Porirua Harbour sediment plate monitoring 2015/2016. Prepared for the Greater Wellington Regional Council. Retrieved from http://www.gw.govt.nz/.

Tagliapietra, D.; Pessa, G.; Cornello, M.; Zitelli, A.; Magni, P. 2016. Temporal distribution of intertidal macrozoobenthic assemblages in a Nanozostera noltii-dominated area (Lagoon of Venice). Marine Environmental Research 114: 31-39.

Tavares, D.S.; Maia, R.C.; Rocha-Barreira, C.; Matthews-Cascon, H. 2015. Ecological relations between mangrove leaf litter and the spatial distribution of the gastropod Melampus coffeus in a fringe mangrove forest. Iheringia Serie Zoologia 105: 35-40.

Thomsen, M.S.; Wernberg, T.; Engelen, A.H.; Tuya, F.; Vanderklift, M.A.; Holmer, M.; McGlathery, K.J.; Arenas, F.; Kotta, J.; Silliman, B.R. 2012. A meta-analysis of seaweed impacts on seagrasses: generalities and knowledge gaps. Plos One 7: e28595.

Thormar, J.; Hasler-Sheetal, H.; Baden, S.; Bostrom, C.; Clausen, K.K.; Krause-Jensen, D.; Olesen, B.; Rasmussen, J.R.; Svensson, C.J.; Holmer, M. 2016. Eelgrass (Zostera marina) food web structure in different environmental settings. Plos One 11: e0146479. 
Tulipani, D.C.; Lipcius, R.N. 2014. Evidence of eelgrass (Zostera marina) seed dispersal by northern diamondback terrapin (Malaclemys terrapin terrapin) in lower Chesapeake Bay. Plos One 9: e103346.

Turner, S.J. 2007. Growth and productivity of intertidal Zostera capricorni in New Zealand estuaries. New Zealand Journal of Marine and Freshwater Research 41: 77-90.

Turner, S.J.; Schwarz, A.M. 2006. Biomass development and photosynthetic potential of intertidal Zostera capricorni in New Zealand estuaries. Aquatic Botany 85: 53-64.

Valentine, J.F.; Duffy, J.E. 2007. The central role of grazing in seagrass ecology. Seagrasses: biology, ecology and conservation, pp 463-501. Springer.

Valentine, J.F.; Heck, K.L.; Cinkovich, A.M. 2002. Impacts of seagrass food webs on marine ecosystems: a need for a broader perspective. Bulletin of Marine Science 71: 1361-1368.

van Houte-Howes, K.S.S.; Turner, S.J.; Pilditch, C.A. 2004. Spatial differences in macroinvertebrate communities in intertidal seagrass habitats and unvegetated sediment in three New Zealand estuaries. Estuaries 27: 945-957.

van Katwijk, M.; Vergeer, L.; Schmitz, G.; Roelofs, J. 1997. Ammonium toxicity in eelgrass Zostera marina. Marine Ecology Progress Series 157: 159-173.

van Katwijk, M.M.; Bos, A.R.; Kennis, P.; de Vries, R. 2010. Vulnerability to eutrophication of a semi-annual life history: A lesson learnt from an extinct eelgrass (Zostera marina) population. Biological Conservation 143: 248-254.

Venables, W.N.; Ripley, B.D. 2002. Modern Applied Statistics with S. Springer, New York. Verhoeven, M.P.; Kelaher, B.P.; Bishop, M.J.; Ralph, P.J. 2012. Epiphyte grazing enhances productivity of remnant seagrass patches. Austral Ecology 37: 885-892.

Vermeer, L.A.; Hunte, W. 2008. Effects of shoot age on leaf growth in the seagrass Thalassia testudinum in Barbados. Aquatic Biology 2: 153-160.

Whalen, M.A.; Duffy, J.E.; Grace, J.B. 2013. Temporal shifts in top-down vs. bottom-up control of epiphytic algae in a seagrass ecosystem. Ecology 94: 510-520.

Wheeler, B.; Torchiano, M. 2016. ImPerm: Permutation Tests for Linear Models. R package version 2.1.0. https://CRAN.R-project.org/package=ImPer.

Winterbourn, M.; Fegley, A. 1989. Effects of nutrient enrichment and grazing on periphyton assemblages in some spring-fed, South Island streams. New Zealand Natural Sciences 16: 57-65.

Winterbourn, M.J. 2016. Life history and ecology of Potamopyrgus estuarinus (Gastropoda: Tateidae) in the tidal reaches of two New Zealand rivers. Molluscan Research 36: 1-7.

Wong, M.C.; Bravo, M.A.; Dowd, M. 2013. Ecological dynamics of Zostera marina (eelgrass) in three adjacent bays in Atlantic Canada. Botanica Marina 56: 413-424. 
Young, D.K.; Buzas, M.A.; Young, M.W. 1976. Species densities of macrobenthos associated with seagrass - field experimental-study of predation. Journal of Marine Research 34: 577592.

Zakhama-Sraieb, R.; Sghaier, Y.R.; Charfi-Cheikhrouha, F. 2006. Is amphipod diversity related to the quality of Posidonia oceanica beds? Biologia Marina Mediterranea 13: 174-180.

Zimmerman, R.C.; Steller, D.L.; Kohrs, D.G.; Alberte, R.S. 2001. Top-down impact through a bottom-up mechanism. In situ effects of limpet grazing on growth, light requirements and survival of the eelgrass Zostera marina. Marine Ecology Progress Series 218: 127-140. 


\section{$\underline{\text { References }}$}

Abal, E.; Loneragan, N.; Bowen, P.; Perry, C.; Udy, J.; Dennison, W. 1994. Physiological and morphological responses of the seagrass Zostera capricorni Aschers, to light intensity. Journal of experimental marine biology and ecology 178: 113-129.

Ahrens, M.J.; Hickey, C.W. 2002. UV-photoactivation of polycyclic aromatic hydrocarbons and the sensitivity of sediment-dwelling estuarine organisms. UV radiation and its effects: an update 2002. Proceedings of a workshop held in Christchurch. RSNZ miscellaneous series, pp 63-65.

Alexandre, A.; Silva, J.; Santos, R. 2016. Nitrogen uptake in light versus darkness of the seagrass Zostera noltei: integration with carbon metabolism. Marine Ecology-an Evolutionary Perspective 37: 1050-1056.

Alfaro, A.C. 2006a. Benthic macro-invertebrate community composition within a mangrove/seagrass estuary in northern New Zealand. Estuarine, Coastal and Shelf Science 66: 97-110.

Alfaro, A.C. 2006b. Tidal migration influences the zonation of grazing snails (Turbo smaragdus) in a mangroveseagrass estuary, northern New Zealand. Estuaries and Coasts 29: 731-736.

Alfaro, A.C.; Thomas, F.; Sergent, L; Duxbury, M. 2006. Identification of trophic interactions within an estuarine food web (northern New Zealand) using fatty acid biomarkers and stable isotopes. Estuarine Coastal and Shelf Science 70: 271-286.

Almeida, C.; Coelho, R.; Silva, M.; Bentes, L.; Monteiro, P.; Ribeiro, J.; Erzini, K.; Goncalves, J.M.S. 2008. Use of different intertidal habitats by faunal communities in a temperate coastal lagoon. Estuarine Coastal and Shelf Science 80: 357-364.

Anscombe, F.J. 1953. Sequential Estimation. Journal of the Royal Statistical Society. Series B (Methodological) 15: $1-29$.

Armitage, A.R.; Fourqurean, J.W. 2006. The short-term influence of herbivory near patch reefs varies between seagrass species. Journal of experimental marine biology and ecology 339: 65-74.

Armitage, A.R.; Frankovich, T.A.; Heck, K.L.; Fourqurean, J.W. 2005. Experimental nutrient enrichment causes complex changes in seagrass, microalgae, and macroalgae community structure in Florida Bay. Estuaries 28: 422434.

Arrontes, J.; Arenas, F.; Fernandez, C.; Rico, J.M.; Oliveros, J.; Martinez, B.; Viejo, R.M.; Alvarez, D. 2004. Effect of grazing by limpets on mid-shore species assemblages in northern Spain. Marine Ecology Progress Series 277: 117133.

Attrill, M.J.; Strong, J.A.; Rowden, A.A. 2000. Are macroinvertebrate communities influenced by seagrass structural complexity? Ecography 23: 114-121.

Azevedo, A.; Dias, J.M.; Lillebo, A.I. 2016. Thriving of Zostera noltei under intertidal conditions: implications for the modelling of seagrass populations. Marine Biology 163.

Batiuk, R.; Orth, R.; Moore, K.; Dennison, W.; Stevenson, J. 1992. Chesapeake Bay submerged aquatic vegetation habitat requirements and restoration targets: A technical synthesis. Virginia Inst. of Marine Science, Gloucester Point, VA (United States). 
Battley, P.F.; Melville, D.S.; Schuckard, R.; Ballance, P.F. 2011. Zostera muelleri as a structuring agent of benthic communities in a large intertidal sandflat in New Zealand. Journal of Sea Research 65: 19-27.

Benedetti-Cecchi, L.; Bulleri, F.; Cinelli, F. 2000. The interplay of physical and biological factors in maintaining midshore and low-shore assemblages on rocky coasts in the north-west Mediterranean. Oecologia 123: 406-417.

Best, R.J.; Stachowicz, J.J. 2014. Phenotypic and phylogenetic evidence for the role of food and habitat in the assembly of communities of marine amphipods. Ecology 95: 775-786.

Bishop, M.J.; Kelaher, B.P.; Sharp, S.M.; Verhoeven, M. 2007. Dispersal of the estuarine gastropod Pyrazus ebeninus is only weakly influenced by pneumatophore density. Journal of experimental marine biology and ecology 340: 62-69.

Blake, R.E.; Duffy, J.E. 2010. Grazer diversity affects resistance to multiple stressors in an experimental seagrass ecosystem. Oikos 119: 1625-1635.

Blake, R.E.; Duffy, J.E. 2012. Changes in biodiversity and environmental stressors influence community structure of an experimental eelgrass Zostera marina system. Marine Ecology Progress Series 470: 41-54.

Blanchet, H.; de Montaudouin, X.; Lucas, A.; Chardy, P. 2004. Heterogeneity of macrozoobenthic assemblages within a Zostera noltii seagrass bed: diversity, abundance, biomass and structuring factors. Estuarine, Coastal and Shelf Science 61: 111-123.

Bloomfield, A.L.; Gillanders, B.M. 2005. Fish and invertebrate assemblages in seagrass, mangrove, saltmarsh, and nonvegetated habitats. Estuaries 28: 63-77.

Boese, B.L.; Alayan, K.E.; Gooch, E.F.; Robbins, B.D. 2003. Desiccation index: a measure of damage caused by adverse aerial exposure on intertidal eelgrass (Zostera marina) in an Oregon (USA) estuary. Aquatic Botany 76: 329-337.

Borowitzka, M.A.; Lethbridge, R.C.; Charlton, L. 1990. Species richness, spatial distribution and colonisation pattern of algal and invertebrate epiphytes on the seagrass Amphibolis griffithii. Marine ecology progress series. Oldendorf64: 281-291.

Bourque, A.S.; Fourqurean, J.W. 2014. Effects of common seagrass restoration methods on ecosystem structure in subtropical seagrass meadows. Marine Environmental Research 97: 67-78.

Brenchley, G.A. 1982. Mechanisms of spatial competition in marine soft-bottom communities. Journal of experimental marine biology and ecology 60: 17-33.

Bryan, K.R.; Tay, H.W.; Pilditch, C.A.; Lundquist, C.J.; Hunt, H.L. 2007. The Effects of Seagrass (Zostera muelleri) on Boundary-layer Hydrodynamics in Whangapoua Estuary, New Zealand. Journal of Coastal Research: 668-672.

Bryars, S.; Collings, G.; Miller, D. 2011. Nutrient exposure causes epiphytic changes and coincident declines in two temperate Australian seagrasses. Marine Ecology Progress Series 441: 89-103.

Bulmer, R.H.; Kelly, S.; Jeffs, A.G. 2016. Light requirements of the seagrass, Zostera muelleri, determined by observations at the maximum depth limit in a temperate estuary, New Zealand. New Zealand Journal of Marine and Freshwater Research 50: 183-194.

Bulthuis, D.A. 1987. Effects of temperature on photosynthesis and growth of seagrasses. Aquatic Botany 27: 2740. 
Burkholder, J.; Glasgow, H.; Cooke, J. 1994. Comparative effects of water-column nitrate enrichment on eelgrass Zostera marina, shoalgrass Halodule wrightii, and widgeongrass Ruppia maritima. Marine Ecology Progress Series 105: 121-138.

Burkholder, J.M.; Tomasko, D.A.; Touchette, B.W. 2007. Seagrasses and eutrophication. Journal of experimental marine biology and ecology 350: 46-72.

Cabaç̧o, S.; Apostolaki, E.T.; García-Marín, P.; Gruber, R.; Hernandez, I.; Martínez-Crego, B.; Mascaro, O.; Perez, M.; Prathep, A.; Robinson, C. 2013. Effects of nutrient enrichment on seagrass population dynamics: evidence and synthesis from the biomass-density relationships. Journal of Ecology 101: 1552-1562.

Cabaço, S.; Machás, R.; Vieira, V.; Santos, R. 2008. Impacts of urban wastewater discharge on seagrass meadows (Zostera noltii). Estuarine, Coastal and Shelf Science 78: 1-13.

Cabaco, S.; Santos, R. 2012. Seagrass reproductive effort as an ecological indicator of disturbance. Ecological Indicators 23: 116-122.

Campanella, J.J.; Bologna, P.A.X.; Smalley, J.V.; Avila, D.N.; Lee, K.N.; Areche, E.C.; Slavin, L.J. 2013. An analysis of the population genetics of restored Zostera marina plantings in Barnegat Bay, New Jersey. Population Ecology 55: $121-133$.

Campbell, J.E.; Fourqurean, J.W. 2014. Ocean acidification outweighs nutrient effects in structuring seagrass epiphyte communities. Journal of Ecology 102: 730-737.

Cardoso, P.G.; Lillebo, A.I.; Pardal, M.A.; Ferreira, S.M.; Marques, J.C. 2002. The effect of different primary producers on Hydrobia ulvae population dynamics: a case study in a temperate intertidal estuary. Journal of experimental marine biology and ecology 277: 173-195.

Cardoso, P.G.; Pardal, M.A.; Lillebo, A.I.; Ferreira, S.M.; Raffaelli, D.; Marques, J.C. 2004. Dynamic changes in seagrass assemblages under eutrophication and implications for recovery. Journal of experimental marine biology and ecology 302: 233-248.

Carr, L.A.; Boyer, K.E. 2014. Variation at multiple trophic levels mediates a novel seagrass-grazer interaction. Marine Ecology Progress Series 508: 117-128.

Carstensen, J.; Krause-Jensen, D.; Balsby, TJ.S. 2016. Biomass-Cover Relationship for Eelgrass Meadows. Estuaries and Coasts 39: 440-450.

Christianen, M.J.A.; Govers, L.L.; Bouma, T.J.; Kiswara, W.; Roelofs, J.G.M.; Lamers, L.P.M.; van Katwijk, M.M. 2012. Marine megaherbivore grazing may increase seagrass tolerance to high nutrient loads. Journal of Ecology 100: 546-560.

Clausen, K.K.; Krause-Jensen, D.; Olesen, B.; Marbà, N. 2014. Seasonality of eelgrass biomass across gradients in temperature and latitude. Marine Ecology Progress Series 506: 71-85.

Connell, J.H. 1972. Community interactions on marine rocky intertidal shores. Annual Review of Ecology and Systematics 3: 169-192.

Connolly, R.M. 1994. A comparison of fish assemblages from seagrass and unvegetated areas of a Southern Australian estuary. Australian Journal of Marine and Freshwater Research 45: 1033-1044.

Cook, K.; Vanderklift, M.A.; Poore, A.G.B. 2011. Strong effects of herbivorous amphipods on epiphyte biomass in a temperate seagrass meadow. Marine Ecology Progress Series 442: 263-269. 
Creed, J.C. 1997. Morphological variation in the seagrass Halodule wrightii near its southern distributional limit. Aquatic Botany 59: 163-172.

Crowe, T. 1996. Different effects of microhabitat fragmentation on patterns of dispersal of an intertidal gastropod in two habitats. Journal of experimental marine biology and ecology 206: 83-107.

Daudi, L.N.; Lugomela, C.; Uku, J.N.; De Troch, M. 2012. Effect of nutrient enrichment on seagrass associated meiofauna in Tanzania. Marine Environmental Research 82: 49-58.

De Angelo, J.A.; Stevens, P.W.; Blewett, D.A.; Switzer, T.S. 2014. Fish Assemblages of Shoal- and ShorelineAssociated Seagrass Beds in Eastern Gulf of Mexico Estuaries. Transactions of the American Fisheries Society 143: 1037-1048.

Deegan, L.A.; Wright, A.; Ayvazian, S.G.; Finn, J.T.; Golden, H.; Merson, R.R.; Harrison, J. 2002. Nitrogen loading alters seagrass ecosystem structure and support of higher trophic levels. Aquatic Conservation-Marine and Freshwater Ecosystems 12: 193-212.

Dennison, W.C.; Orth, R.J; Moore, K.A.; Stevenson, J.C.; Carter, V.; Kollar, S.; Bergstrom, P.W.; Batiuk, R.A. 1993. Assessing water quality with submersed aquatic vegetation. Bioscience 43: 86-94.

Dolbeth, M.; Pardal, M.; Lillebø, A.; Azeiteiro, U.; Marques, J. 2003. Short-and long-term effects of eutrophication on the secondary production of an intertidal macrobenthic community. Marine Biology 143: 1229-1238.

Dos Santos, V.M.; Matheson, F.E.; Pilditch, C.A.; Elger, A. 2012. Is black swan grazing a threat to seagrass? Indications from an observational study in New Zealand. Aquatic Botany 100: 41-50.

Dos Santos, V.M.; Matheson, F.E.; Pilditch, C.A.; Elger, A. 2013. Seagrass resilience to waterfowl grazing in a temperate estuary: A multi-site experimental study. Journal of experimental marine biology and ecology 446: 194-201.

Douglass, J.G.; Duffy, J.E.; Canuel, E.A. 2011. Food Web Structure in a Chesapeake Bay Eelgrass Bed as Determined through Gut Contents and C-13 and N-15 Isotope Analysis. Estuaries and Coasts 34: 701-711.

Duarte, C.M. 1991. Allometric scaling of seagrass form and productivity. Marine ecology progress series. Oldendorf 77: 289-300.

Duarte, C.M. 2002. The future of seagrass meadows. Environmental Conservation 29: 192-206.

Duffy, J.E. 2006. Biodiversity and the functioning of seagrass ecosystems. Marine Ecology Progress Series 311: $233-250$.

Duffy, J.E.; Reynolds, P.L.; Boström, C.; Coyer, J.A.; Cusson, M.; Donadi, S.; Douglass, J.G.; Eklöf, J.S.; Engelen, A.H.; Eriksson, B.K. 2015. Biodiversity mediates top-down control in eelgrass ecosystems: a global comparativeexperimental approach. Ecology Letters 18: 696-705.

Duffy, J.E.; Richardson, J.P.; Canuel, E.A. 2003. Grazer diversity effects on ecosystem functioning in seagrass beds. Ecology Letters 6: 637-645.

Duncan, A. 2015. Seagrass Condition in Te Awarua-o-Porirua Harbour. Report prepared for VUW Summer Scholarship Programme 2014/15. (referenced in Milne J. and Oliver M. 2015. Te Awarua-O Porirua Harbour and catchment-science update. (Report PCC 1103574.)). 
Ebrahim, A.; Olds, A.D.; Maxwell, P.S.; Pitt, K.A.; Burfeind, D.D.; Connolly, R.M. 2014. Herbivory in a subtropical seagrass ecosystem: separating the functional role of different grazers. Marine Ecology Progress Series 511: 8391.

Edgar, GJ. 1990. Population regulation, population dynamics and competition amongst mobile epifauna associated with seagrass. Journal of experimental marine biology and ecology 144: 205-234.

Eldridge, P.M.; Morse, J.W. 2000. A diagenetic model for sediment-seagrass interactions. Marine Chemistry 70: 89-103.

Enríquez, S.; Agusti, S.; Duarte, C. 1992. Light absorption by seagrass Posidonia oceanica leaves. pp 201-204. InterResearch Nordbunte 23, D-21385 Oldendorf Luhe, Germany.

Farina, S.; Tomas, F.; Prado, P.; Romero, J.; Alcoverro, T. 2009. Seagrass meadow structure alters interactions between the sea urchin Paracentrotus lividus and its predators. Marine Ecology Progress Series 377: 131-137.

Fawcett, M.H. 1984. Local and latitudinal variation in predation on an herbivorous marine snail. Ecology 65: 12141230.

Fish, J.; Fish, S. 1974. The breeding cycle and growth of Hydrobia ulvae in the Dovey estuary. Journal of the Marine Biological Association of the United Kingdom 54: 685-697.

Flaherty, K.E.; Switzer, T.S.; Winner, B.L; Keenan, S.F. 2014. Regional Correspondence in Habitat Occupancy by Gray Snapper (Lutjanus griseus) in Estuaries of the Southeastern United States. Estuaries and Coasts 37: 206-228.

Gacia, E.; Costalago, D.; Prado, P.; Piorno, D.; Tomas, F. 2009. Mesograzers in Posidonia oceanica meadows: an update of data on gastropod-epiphyte-seagrass interactions. Botanica Marina 52: $439-447$.

Gacia, E.; Duarte, C.M. 2001. Sediment retention by a Mediterranean Posidonia oceanica meadow: the balance between deposition and resuspension. Estuarine, Coastal and Shelf Science 52: 505-514.

Gartner, A.; Lavery, P.S.; McMahon, K.; Brearley, A.; Barwick, H. 2010. Light reductions drive macroinvertebrate changes in Amphibolis griffithii seagrass habitat. Marine Ecology Progress Series 401: 87-100.

Gobert, S.; Cambridge, M.T.; Velimirov, B.; Pergent, G.; Lepoint, G.; Bouquegneau, J.-M.; Dauby, P.; PergentMartini, C.; Walker, D.I. 2007. Biology of Posidonia. Seagrasses: Biology, Ecology and Conservation, pp 387-408. Springer.

Green, E.P.; Short, F.T. 2003. World atlas of seagrasses. Univ of California Press.

Greve, T.M.; Binzer, T. 2004. Which factors regulate seagrass growth and distribution. European seagrasses: an introduction to monitoring and management. Monitoring and Managing of European Seagrasses Project (M\&MS): 19-23.

Harrell JR, F.E. and with contributions from Charles Dupont and many others. 2016. Hmisc: Harrell Miscellaneous. R package version 4.0-2. https://CRAN.R-project.org/package=Hmisc.

Hasegawa, N.; Hori, M.; Mukai, H. 2007. Seasonal shifts in seagrass bed primary producers in a cold-temperate estuary: Dynamics of eelgrass Zostera marina and associated epiphytic algae. Aquatic Botany 86: 337-345.

Hasegawa, N.; Hori, M.; Mukai, H. 2008. Seasonal changes in eelgrass functions: current velocity reduction, prevention of sediment resuspension, and control of sediment-water column nutrient flux in relation to eelgrass dynamics. Hydrobiologia 596: 387-399. 
Hauxwell, J.; Cebrián, J.; Furlong, C.; Valiela, I. 2001. Macroalgal canopies contribute to eelgrass (Zostera marina) decline in temperate estuarine ecosystems. Ecology 82: 1007-1022.

Hay, M.E.; Parker, J.D.; Burkepile, D.E.; Caudill, C.C.; Wilson, A.E.; Hallinan, Z.P.; Chequer, A.D. 2004. Mutualisms and aquatic community structure: The enemy of my enemy is my friend. Annual Review of Ecology Evolution and Systematics 35: 175-197.

Heck, K.L.; Able, K.W.; Roman, C.T.; Fahay, M.P. 1995. Composition, abundance, biomass and production of macrofauna in a New-England estuary- comparisons among eelgrass meadows and other nursery habitats. Estuaries 18: 379-389.

Heck, K.L.; Hays, G.; Orth, R.J. 2003. Critical evaluation of the nursery role hypothesis for seagrass meadows. Marine Ecology Progress Series 253: 123-136.

Heck, K.L., Jr.; Valentine, J.F. 2007. The primacy of top-down effects in shallow benthic ecosystems. Estuaries and Coasts 30: 371-381.

Heck, K.L.; Valentine, J.F. 2006. Plant-herbivore interactions in seagrass meadows. Journal of experimental marine biology and ecology 330: 420-436.

Hily, C.; Connan, S.; Raffin, C.; Wyllie-Echeverria, S. 2004. In vitro experimental assessment of the grazing pressure of two gastropods on Zostera marina L. ephiphytic algae. Aquatic Botany 78: 183-195.

Holzer, K.K.; Rueda, J.L.; McGlathery, KJ. 2011. Differences in the Feeding Ecology of Two Seagrass-Associated Snails. Estuaries and Coasts 34: 1140-1149.

Hothorn, T.; Bretz, F.; Westfall, P. 2008. Simultaneous Inference in General Parametric Models. Biometrical Journal 50: 346-363.

Hovey, R.K.; Cambridge, M.L.; Kendrick, G.A. 2012. Season and sediment nutrient additions affect root architecture in the temperate seagrasses Posidonia australis and P. sinuosa. Marine Ecology Progress Series 446: 23-30.

Hughes, A.R.; Bando, K.J.; Rodriguez, L.F.; Williams, S.L. 2004. Relative effects of grazers and nutrients on seagrasses: a meta-analysis approach. Marine Ecology Progress Series 282: 87-99.

Irlandi, E.A.; Orlando, B.A.; Cropper, W.P., Jr. 2004. Short-term effects of nutrient addition on growth and biomass of Thalassia testudinum in Biscayne Bay, FL. Florida Scientist 67: 18-26.

Jenkins, S.; Coleman, R.; Della Santina, P.; Hawkins, S.; Burrows, M.; Hartnoll, R. 2005. Regional scale differences in the determinism of grazing effects in the rocky intertidal. Marine Ecology Progress Series 287: 77-86.

Jeong, S..; Suh, H.L.; Kang, C.K. 2012. Trophic diversity in amphipods within a temperate eelgrass ecosystem as determined by gut contents and C and N isotope analysis. Marine Biology 159: 1943-1954.

Jernakoff, P.; Nielsen, J. 1997. The relative importance of amphipod and gastropod grazers in Posidonia sinuosa meadows. Aquatic Botany 56: 183-202.

Jones, N. 1946. Browsing of Patella. Nature 158: 557-558.

Jones, T.C.; Gemmill, C.E.C.; Pilditch, C.A. 2008. Genetic variability of New Zealand seagrass (Zostera muelleri) assessed at multiple spatial scales. Aquatic Botany 88: 39-46. 
Jorgensen, P.; Ibarra-Obando, S.E.; Carriquiry, J.D. 2007. Top-down and bottom-up stabilizing mechanisms in eelgrass meadows differentially affected by coastal upwelling. Marine Ecology Progress Series 333: 81-93.

Kaewsrikhaw, R.; Ritchie, R.J.; Prathep, A. 2016. Variations of tidal exposures and seasons on growth, morphology, anatomy and physiology of the seagrass Halophila ovalis (R.Br.) Hook. f. in a seagrass bed in Trang Province, Southern Thailand. Aquatic Botany 130: 11-20.

Kaldy, J.E.; Fowler, N.; Dunton, K.H. 1999. Critical assessment of Thalassia testudinum (turtle grass) aging techniques: implications for demographic inferences. Marine Ecology Progress Series 181: 279-288.

Kennish, M.J.; Sakowicz, G.P.; Fertig, B. 2016. Recent trends of Zostera marina (eelgrass) in a highly eutrophic coastal lagoon in the mid-Atlantic region (USA). Open Journal of Ecology 6: 243-253.

Kerr, E.A.; Strother, S. 1989. Seasonal changes in leaf growth rate of Zostera muelleri Irmisch ex Aschers. In SouthEastern Australia. Aquatic Botany 33: 131-140.

Kerr, E.A.; Strother, S. 1990. Seasonal-changes in standing crop of Zostera muelleri in South-Eastern Australia. Aquatic Botany 38: 369-376.

Kharlamenko, V.I.; Kiyashko, S.I.; Imbs, A.B.; Vyshkvartzev, D.I. 2001. Identification of food sources of invertebrates from the seagrass Zostera marina community using carbon and sulfur stable isotope ratio and fatty acid analyses. Marine Ecology Progress Series 220: 103-117.

Kim, J.B.; Lee, W.-C.; Lee, K.-S.; Park, J.-I. 2013. Growth dynamics of eelgrass, Zostera marina, in the intertidal zone of Seomjin Estuary, Korea. Ocean Science Journal 48: 239-250.

Kim, Y.K.; Kim, J.-H.; Kim, S.H.; Kim, J.W.; Park, S.R.; Lee, K.-S. 2012. Growth dynamics of the seagrass, Zostera marina in Jindong Bay on the southern coast of Korea. Algae 27: 215-224.

Kohlmeier, D.; Pilditch, C.A.; Bornman, J.F.; Bischof, K. 2014. Site specific differences in morphometry and photophysiology in intertidal Zostera muelleri meadows. Aquatic Botany 116: 104-109.

Kowalski, J.L.; DeYoe, H.R.; Allison, T.C.; Kaldy, J.E. 2001. Productivity estimation in Halodule wrightii Aschers: comparison of leaf-clipping and leaf-marking techniques and the importance of clip height. Marine Ecology Progress Series 220: 131-136.

Leduc, D.; Probert, P.; Duncan, A. 2009. A multi-method approach for identifying meiofaunal trophic connections. Marine Ecology Progress Series 383: 95-111.

Leduc, D.; Probert, P.K. 2011. Small-scale effect of intertidal seagrass (Zostera muelleri) on meiofaunal abundance, biomass, and nematode community structure. Journal of the Marine Biological Association of the United Kingdom 91: 579-591.

Leduc, D.; Probert, P.K.; Frew, R.D.; Hurd, C.L. 2006. Macroinvertebrate diet in intertidal seagrass and sandflat communities: a study using $\mathrm{C}, \mathrm{N}$, and S stable isotopes. New Zealand Journal of Marine and Freshwater Research 40: 615-629.

Leopardas, V.; Honda, K.; Go, G.A.; Bolisay, K.; Pantallano, A.D.; Uy, W.; Fortes, M.; Nakaoka, M. 2016. Variation in macrofaunal communities of seagrass beds along a pollution gradient in Bolinao, northwestern Philippines.

Marine Pollution Bulletin 105: 310-318.

Les, D.H.; Moody, M.L.; Jacobs, S.W.; Bayer, R.J. 2002. Systematics of seagrasses (Zosteraceae) in Australia and New Zealand. Systematic Botany: 468-484. 
Lillebo, A.I.; Pardal, M.A.; Marques, J.C. 1999. Population structure, dynamics and production of Hydrobia ulvae (Pennant) (Mollusca : Prosobranchia) along an eutrophication gradient in the Mondego estuary (Portugal). Acta Oecologica-International Journal of Ecology 20: 289-304.

Malaquias, M.A.E.; Sprung, M.J. 2005. Population biology of the cephalaspidean mollusc Haminoea orbygniana in a temperate coastal lagoon (Ria Formosa, Portugal). Estuarine, Coastal and Shelf Science 63: 177-185.

Matheson, F.; Reed, J.; Dos Santos, V.M.; Cummings, V.J.; MacKay, G.; Jordan, M. 2009. Seagrass restoration in Whangarei Harbour: Results of a small-scale transplantation trial. NIWA Consultancy Report for Northland Regional Council HAM2008-063, 25 p.

Matheson, F.; Wadha, S. 2012. Seagrass in the Porirua Harbour. Preliminary Assessment of Restoration Potential. Prepared for the Greater Wellington Regional Council. Retrieved from http://www.gw.govt.nz/assets/Seagrassrestoration-in-Porirua-Harbour.pdf.

Matheson, F.E.; Schwarz, A.M. 2007. Growth responses of Zostera capricorni to estuarine sediment conditions. Aquatic Botany 87: 299-306.

McCloskey, R.M.; Unsworth, R.K. 2015. Decreasing seagrass density negatively influences associated fauna. PeerJ 3: e1053.

McMahon, R.F. 1990. Thermal tolerance, evaporative water-loss, air-water oxygen-consumption and zonation of intertidal prosobranchs - a new synthesis. Hydrobiologia 193: 241-260.

McSkimming, C.; Connell, S.D.; Russell, B.D.; Tanner, J.E. 2016. Habitat restoration: Early signs and extent of faunal recovery relative to seagrass recovery. Estuarine Coastal and Shelf Science 171: 51-57.

McSkimming, C.; Tanner, J.E.; Russell, B.D.; Connell, S.D. 2015. Compensation of nutrient pollution by herbivores in seagrass meadows. Journal of experimental marine biology and ecology 471: 112-118.

Miller, A.A.; Poulin, R. 2001. Parasitism, movement, and distribution of the snail Diloma subrostrata (Trochidae) in a soft-sediment intertidal zone. Canadian journal of zoology 79: 2029-2035.

Miller, C.J.; Campbell, S.J.; Scudds, S. 2005. Spatial variation of Zostera tasmanica morphology and structure across an environmental gradient. Marine Ecology Progress Series 304: 45-53.

Mills, V.S.; Berkenbusch, K. 2009. Seagrass (Zostera muelleri) patch size and spatial location influence infaunal macroinvertebrate assemblages. Estuarine Coastal and Shelf Science 81: 123-129.

Moore, K.A.; Short, F.T. 2007. Zostera: biology, ecology, and management. Seagrasses: Biology, Ecology and Conservation, pp 361-386. Springer.

Moore, K.A.; Wetzel, R.L. 2000. Seasonal variations in eelgrass (Zostera marina L.) responses to nutrient enrichment and reduced light availability in experimental ecosystems. Journal of experimental marine biology and ecology 244: 1-28.

Morelissen, B. 2012. Ecological effects of Undaria pinnatifida (Harvey) Suringar and nutrient-enrichment on intertidal assemblages in the Wellington region of New Zealand. School of Biological Sciences. Victoria University of Wellington, Wellington, New Zealand.

Morrison, M.; Francis, M.; Hartill, B.; Parkinson, D. 2002. Diurnal and tidal variation in the abundance of the fish fauna of a temperate tidal mudflat. Estuarine, Coastal and Shelf Science 54: 793-807. 
Nakano, T.; Marshall, B.A.; Kennedy, M.; Spencer, H.G. 2009. The phylogeny and taxonomy of New Zealand Notoacmea and Patelloida species (Mollusca: Patellogastropoda: Lottiidae) inferred from DNA sequences. Molluscan Research 29: 33.

Nakano, T.; Spencer, H.G. 2007. Simultaneous polyphenism and cryptic species in an intertidal limpet from New Zealand. Molecular phylogenetics and evolution 45: 470-479.

Nelson, T.A.; Waaland, J.R. 1997. Seasonality of eelgrass, epiphyte, and grazer biomass and productivity in subtidal eelgrass meadows subjected to moderate tidal amplitude. Aquatic Botany 56: 51-74.

Norberg, J. 2000. Resource-niche complementarity and autotrophic compensation determines ecosystem-level responses to increased cladoceran species richness. Oecologia 122: 264-272.

Ollivier, Q.R.; Bramwell, N.A.; Hammill, E.; Foster-Thorpe, C.; Booth, D.J. 2015. Are the effects of adjacent habitat type on seagrass gastropod communities being masked by previous focus on habitat dyads? Australian Journal of Zoology 63: 357-363.

Olsen, Y.S.; Fox, S.E.; Teichberg, M.; Otter, M.; Valiela, I. 2011. $\delta 15 \mathrm{~N}$ and $\delta 13 \mathrm{C}$ reveal differences in carbon flow through estuarine benthic food webs in response to the relative availability of macroalgae and eelgrass. Marine Ecology Progress Series 421: 83-96.

Orth, RJ.; Van Montfrans, J. 1984. Epiphyte-seagrass relationships with an emphasis on the role of micrograzing: a review. Aquatic Botany 18: 43-69.

Orvain, F.; Sauriau, P.-G. 2002. Environmental and behavioural factors affecting activity in the intertidal gastropod Hydrobia ulvae. Journal of experimental marine biology and ecology 272: 191-216.

Ott, J.A. 1980. Growth and production in Posidonia oceanica (L.) Delile. Marine Ecology 1: 47-64.

Paavo, B.L.; Ham, D.; Gorlitz, S.; Probert, P.K. 2012. How does tidal submersion time affect macroinvertebrate community patterns on a temperate sheltered sandflat? Marine and Freshwater Research 63: 68-77.

Park, S. 2011. Sea Lettuce and Nutrient Monitoring in Tauranga Harbour 1991-2010. Prepared for Bay of Plenty Regional Council. ISSN: 1179 9471. Retrieved from https://www.boprc.govt.nz.

Park, S. 2016. Extent of seagrass in the Bay of Plenty. Bay of Plenty Regional Council Environmental Publication 2016/03. Whakatane, New Zealand. Retrieved from: www.boprc.govt.nz.

Parsons, D.M.; Buckthought, D.; Middleton, C.; MacKay, G. 2016. Relative abundance of snapper (Chrysophrys auratus) across habitats within an estuarine system. New Zealand Journal of Marine and Freshwater Research 50: 358-370.

Parsons, D.M.; Middleton, C.; Smith, M.D.; Cole, R.G. 2014. The influence of habitat availability on juvenile fish abundance in a northeastern New Zealand estuary. New Zealand Journal of Marine and Freshwater Research 48: 216-228.

Parsons, D.M.; Middleton, C.; Spong, K.T.; Mackay, G.; Smith, M.D.; Buckthought, D. 2015. Mechanisms explaining nursery habitat association: how do juvenile snapper (Chrysophrys auratus) benefit from their nursery habitat? Plos One 10: 0122137.

Parsons, D.M.; Morrison, M.A.; Thrush, S.F.; Middleton, C.; Smith, M.; Spong, K.T.; Buckthought, D. 2013. The influence of habitat structure on juvenile fish in a New Zealand estuary. Marine Ecology-an Evolutionary Perspective 34: 492-500. 
Penhale, P.A.; Smith, W.O. 1977. Excretion of dissolved organic carbon by eelgrass (Zostera marina) and its epiphytes. Limnol. Oceanogr 22: 400-407.

Peterson, C.H. 1982. Clam predation by whelks (Busycon spp.): experimental tests of the importance of prey size, prey density, and seagrass cover. Marine Biology 66: 159-170.

Phillips, N.E.; Hutchison, E. 2008. Grazer effects on algal assemblages and mussel recruitment in two different mid-intertidal communities in the Cook Strait, New Zealand. New Zealand Journal of Marine and Freshwater Research 42: 297-306.

Piazzi, L.; Balata, D.; Ceccherelli, G. 2016. Epiphyte assemblages of the Mediterranean seagrass Posidonia oceanica: an overview. Marine Ecology-an Evolutionary Perspective 37: 3-41.

Poore, A.G.B.; Campbell, A.H.; Steinberg, P.D. 2009. Natural densities of mesograzers fail to limit growth of macroalgae or their epiphytes in a temperate algal bed. Journal of Ecology 97: 164-175.

R-Core-Team. 2016. R: A Language and Environment for Statistical Computing. R Foundation for Statistical Computing, Vienna, Austria. URL https://www.R-project.org/.

Ralph, P.J.; Durako, M.J.; Enriquez, S.; Collier, C.J.; Doblin, M.A. 2007. Impact of light limitation on seagrasses. Journal of experimental marine biology and ecology 350: 176-193.

Reynolds, L.K.; Carr, L.A.; Boyer, K.E. 2012. A non-native amphipod consumes eelgrass inflorescences in San Francisco Bay. Marine Ecology Progress Series 451: 107-118.

Reynolds, L.K.; Marino, R.; Muth, M.F.; McLenaghan, N.; Hayn, M.; Tyler, A.C.; McGlathery, KJ.; Howarth, R.W. 2015. Evidence of grazer control on nitrogen fixation by eelgrass epiphytes in a temperate coastal bay. Marine Ecology Progress Series 526: 11-19.

Rowden, A.; Berkenbusch, K.; Brewin, P.; Dalen, J.; Neill, K.; Nelson, W.; Oliver, M.; Probert, P.; Schwarz, A.; Sui, P. 2012. A review of the marine soft-sediment assemblages of New Zealand. NZ Aquatic Environment and Biodiversity Report.

RStudio. Team (2015). RStudio: Integrated Development for R. RStudio, Inc., Boston, MA URL http://www.rstudio.com/.

Rubio, L.; Linares-Rueda, A.; García-Sánchez, M.J.; Fernández, J.A. 2007. Ammonium uptake kinetics in root and leaf cells of Zostera marina L. Journal of experimental marine biology and ecology 352: 271-279.

Ruesink, J.L. 2016. Epiphyte load and seagrass performance are decoupled in an estuary with low eutrophication risk. Journal of experimental marine biology and ecology 481: 1-8.

Sandoval-Gil, J.M.; Ruiz, J.M.; Marin-Guirao, L.; Bernardeau-Esteller, J.; Sanchez-Lizaso, J.L. 2014. Ecophysiological plasticity of shallow and deep populations of the Mediterranean seagrasses Posidonia oceanica and Cymodocea nodosa in response to hypersaline stress. Marine Environmental Research 95: 39-61.

Schindler, D.E.; Johnson, B.M.; Mackay, N.A.; Bouwes, N.; Kitchell, J.F. 1994. Crab-snail size structured interactions and salt marsh predation gradients. Oecologia 97: 49-61.

Schultz, S.T.; Kruschel, C.; Bakran-Petricioli, T. 2009. Influence of seagrass meadows on predator-prey habitat segregation in an Adriatic lagoon. Marine Ecology Progress Series 374: 85-99. 
Schwarz, A.-M.; Morrison, M.; Hawes, l.; Halliday, J. 2006. Physical and biological characteristics of a rare marine habitat: sub-tidal seagrass beds of offshore islands. Science for Conservation (Wellington) 269: 1-39.

Schwarz, A.M. 2004. Contribution of photosynthetic gains during tidal emersion to production of Zostera capricomi in a North Island, New Zealand estuary. New Zealand Journal of Marine and Freshwater Research 38: 809-818.

Short, F.T.; Wyllie-Echeverria, S. 1996. Natural and human-induced disturbance of seagrasses. Environmental Conservation 23: 17-27.

Skilleter, G.A.; Wegscheidl, C.; Lanyon, J.M. 2007. Effects of grazing by a marine mega-herbivore on benthic assemblages in a subtropical seagrass bed. Marine Ecology Progress Series 351: 287-300.

Smyth, A.R.; Thompson, S.P.; Siporin, K.N.; Gardner, W.S.; McCarthy, M.J.; Piehler, M.F. 2013. Assessing Nitrogen Dynamics Throughout the Estuarine Landscape. Estuaries and Coasts 36: 44-55.

Sola, J.C. 1996. Population dynamics, reproduction, growth, and secondary production of the mud-snail hydrobia ulvae (Pennant). Journal of experimental marine biology and ecology 205: 49-62.

Solana-Arellano, E.; Echavarria-Heras, H.; Franco-Vizcaino, E. 2010. A dynamical model for characterising seasonality effects on eelgrass plastochron intervals. Annals of Applied Biology 157: 99-110.

Sprung, M. 1994. Macrobenthic secondary production in the intertidal zone of the Ria Formosa-a lagoon in southern Portugal. Estuarine, Coastal and Shelf Science 38: 539-558.

Stevens, L.; Robertson, B. 2013. Porirua Harbour Broad Scale Habitat Mapping 2012/13. Prepared for the Greater Wellington Regional Council. Retrieved from http://www.gw.govt.nz/.

Stevens, L.; Robertson, B. 2014. Porirua Harbour Intertidal Macroalgal Monitoring 2013/14. Prepared for the Greater Wellington Regional Council. Retrieved from http://www.gwrc.govt.nz/.

Stevens, L.; Robertson, B. 2016. Porirua Harbour Sediment Plate monitoring 2015/2016. Prepared for the Greater Wellington Regional Council. Retrieved from http://www.gw.govt.nz/.

Tagliapietra, D.; Pessa, G.; Cornello, M.; Zitelli, A.; Magni, P. 2016. Temporal distribution of intertidal macrozoobenthic assemblages in a Nanozostera noltii-dominated area (Lagoon of Venice). Marine Environmental Research 114: 31-39.

Tavares, D.S.; Maia, R.C.; Rocha-Barreira, C.; Matthews-Cascon, H. 2015. Ecological relations between mangrove leaf litter and the spatial distribution of the gastropod Melampus coffeus in a fringe mangrove forest. Iheringia Serie Zoologia 105: 35-40.

Thomsen, M.S.; Wernberg, T.; Engelen, A.H.; Tuya, F.; Vanderklift, M.A.; Holmer, M.; McGlathery, KJ.; Arenas, F.; Kotta, J.; Silliman, B.R. 2012. A meta-analysis of seaweed impacts on seagrasses: generalities and knowledge gaps. Plos One 7: e28595.

Thormar, J.; Hasler-Sheetal, H.; Baden, S.; Bostrom, C.; Clausen, K.K.; Krause-Jensen, D.; Olesen, B.; Rasmussen, J.R.; Svensson, C.J.; Holmer, M. 2016. Eelgrass (Zostera marina) Food Web Structure in Different Environmental Settings. Plos One 11.

Tulipani, D.C.; Lipcius, R.N. 2014. Evidence of Eelgrass (Zostera marina) Seed Dispersal by Northern Diamondback Terrapin (Malaclemys terrapin terrapin) in Lower Chesapeake Bay. Plos One 9. 
Turner, S.J. 2007. Growth and productivity of intertidal Zostera capricorni in New Zealand estuaries. New Zealand Journal of Marine and Freshwater Research 41: 77-90.

Turner, S.J.; Schwarz, A.M. 2006. Biomass development and photosynthetic potential of intertidal Zostera capricorni in New Zealand estuaries. Aquatic Botany 85: 53-64.

Valentine, J.F.; Duffy, J.E. 2007. The central role of grazing in seagrass ecology. SEAGRASSES: BIOLOGY, ECOLOGYAND CONSERVATION, pp 463-501. Springer.

Valentine, J.F.; Heck, K.L.; Cinkovich, A.M. 2002. Impacts of seagrass food webs on marine ecosystems: a need for a broader perspective. Bulletin of Marine Science 71: 1361-1368.

van Houte-Howes, K.S.S.; Turner, S.J.; Pilditch, C.A. 2004. Spatial differences in macroinvertebrate communities in intertidal seagrass habitats and unvegetated sediment in three New Zealand estuaries. Estuaries 27: 945-957.

van Katwijk, M.; Vergeer, L.; Schmitz, G.; Roelofs, J. 1997. Ammonium toxicity in eelgrass Zostera marina. Marine Ecology Progress Series 157: 159-173.

van Katwijk, M.M.; Bos, A.R.; Kennis, P.; de Vries, R. 2010. Vulnerability to eutrophication of a semi-annual life history: A lesson learnt from an extinct eelgrass (Zostera marina) population. Biological Conservation 143: 248254.

Venables, W.N.; Ripley, B.D. 2002. Modern Applied Statistics with S. Springer, New York.

Verhoeven, M.P.; Kelaher, B.P.; Bishop, MJ.; Ralph, P.J. 2012. Epiphyte grazing enhances productivity of remnant seagrass patches. Austral Ecology 37: 885-892.

Vermeer, L.A.; Hunte, W. 2008. Effects of shoot age on leaf growth in the seagrass Thalassia testudinum in Barbados. Aquatic Biology 2: 153-160.

Whalen, M.A.; Duffy, J.E.; Grace, J.B. 2013. Temporal shifts in top-down vs. bottom-up control of epiphytic algae in a seagrass ecosystem. Ecology 94:510-520.

Wheeler, B.; Torchiano, M. 2016. ImPerm: Permutation Tests for Linear Models. . R package version 2.1.0. https://CRAN.R-project.org/package=ImPer.

Winterbourn, M.; Fegley, A. 1989. Effects of nutrient enrichment and grazing on periphyton assemblages in some spring-fed, South Island streams. New Zealand Natural Sciences 16: 57-65.

Winterbourn, M.J. 2016. Life history and ecology of Potamopyrgus estuarinus (Gastropoda: Tateidae) in the tidal reaches of two New Zealand rivers. Molluscan Research: 1-7.

Wong, M.C.; Bravo, M.A.; Dowd, M. 2013. Ecological dynamics of Zostera marina (eelgrass) in three adjacent bays in Atlantic Canada. Botanica Marina 56: 413-424.

Young, D.K.; Buzas, M.A.; Young, M.W. 1976. Species densities of macrobenthos associated with seagrass - field experimental-study of predation. Journal of Marine Research 34: 577-592.

Zakhama-Sraieb, R.; Sghaier, Y.R.; Charfi-Cheikhrouha, F. 2006. Is amphipod diversity related to the quality of Posidonia oceanica beds? Biologia Marina Mediterranea 13: 174-180. 
Zimmerman, R.C.; Steller, D.L.; Kohrs, D.G.; Alberte, R.S. 2001. Top-down impact through a bottom-up mechanism. In situ effects of limpet grazing on growth, light requirements and survival of the eelgrass Zostera marina. Marine Ecology Progress Series 218: 127-140. 


\section{Appendix}

Table A2.1: Summary of species collected during 2016. Densities are presented as the total number of individuals per $\mathrm{g}$ dry seagrass per $\mathrm{m}^{2}$.

\begin{tabular}{|c|c|c|c|c|c|c|c|c|}
\hline & & & \multicolumn{3}{|c|}{ Summer } & \multicolumn{3}{|c|}{ Winter } \\
\hline Phylum & Family & Species & BB & PS & $\mathrm{E}$ & BB & PS & $\mathrm{E}$ \\
\hline \multirow{19}{*}{ Mollusca } & \multirow{19}{*}{ Gastropoda } & Cominella sp. egg capsules & 1871.5 & 0 & 322.0 & 0 & 0 & 0 \\
\hline & & $\begin{array}{l}\text { Cominella glandiformis } \\
\text { (adults) }\end{array}$ & 74.6 & 272.1 & 14.4 & 32.2 & 23.8 & 0 \\
\hline & & $\begin{array}{l}\text { Cominella glandiformis } \\
\text { (juveniles) }\end{array}$ & 0 & 0 & 70.8 & 86.9 & 0 & 0 \\
\hline & & Retimohinia acadiana & 18.3 & 0 & 0 & 29.8 & 0 & 0 \\
\hline & & Xymene pleibius & 62.1 & 28.5 & 14.8 & 53.2 & 0 & 0 \\
\hline & & C. ovata & 59.8 & 0 & 0 & 0 & 0 & 0 \\
\hline & & Potamopyrgus estuarinus & 74.8 & 5466.2 & 99.6 & 36.7 & 3611.2 & 519.9 \\
\hline & & Notoacmea scapha & 6864.16 & 2343.1 & 732.1 & 3389.3 & 580.2 & 1180.4 \\
\hline & & Diloma subrostrata (adults) & 303.0 & 67.3 & 79.5 & 92.1 & 0 & 8.7 \\
\hline & & Diloma arida (adults) & 160.4 & 76.0 & 173.0 & 350.2 & 0 & 26.6 \\
\hline & & Diloma zelandica (adults) & 124.2 & 47.8 & 304.4 & 12 & 0 & 0 \\
\hline & & Diloma spp. juveniles & 0 & 0 & 3.8 & 22.9 & 0 & 12.6 \\
\hline & & $\begin{array}{l}\text { Micrelenchus tenebrosus } \\
\text { (adults) }\end{array}$ & 257.4 & 25.4 & 108.5 & 209.5 & 167.9 & 100.2 \\
\hline & & $\begin{array}{l}\text { Micrelenchus sanguineus } \\
\text { (adults) }\end{array}$ & 66.4 & 81.8 & 8.0 & 37.4 & 0 & 0 \\
\hline & & Micrelenchus spp. (juveniles) & 474.4 & 148.6 & 16.84 & 211.1 & 296.1 & 21.2 \\
\hline & & $\begin{array}{l}\text { Zeacumantus lutulentus } \\
\text { (adults) }\end{array}$ & 228.4 & 388.4 & 35.7 & 557.6 & 274.3 & 18.5 \\
\hline & & Z. lutulentus (juveniles) & 47.3 & 917.8 & 11.1 & 130.6 & 28.2 & 9.3 \\
\hline & & Epitonium jukesianum & 35.7 & 0 & 20.2 & 80.3 & 0 & 0 \\
\hline & & Turbonilla spp. & 127.7 & 39.8 & 15.2 & 0 & 35.7 & 25.6 \\
\hline
\end{tabular}


Table A2.1 continued.

\begin{tabular}{|c|c|c|c|c|c|c|c|c|}
\hline \multirow[b]{2}{*}{ Phylum } & \multirow[b]{2}{*}{ Family } & \multirow[b]{2}{*}{ Species } & \multicolumn{3}{|c|}{ Summer } & \multicolumn{3}{|c|}{ Winter } \\
\hline & & & BB & PS & $E$ & $\mathrm{BB}$ & PS & $E$ \\
\hline \multirow{8}{*}{ Mollusca } & \multirow{5}{*}{ Gastropoda } & Z. Iutulentus (juveniles) & 47.3 & 917.8 & 11.1 & 130.6 & 28.2 & 9.3 \\
\hline & & Epitonium jukesianum & 35.7 & 0 & 20.2 & 80.3 & 0 & 0 \\
\hline & & Turbonilla spp. & 127.7 & 39.8 & 15.2 & 0 & 35.7 & 25.6 \\
\hline & & Haminoea zelandiae (adults) & 0 & 0 & 5.5 & 0 & 0 & 15.1 \\
\hline & & H. zelandiae (juveniles) & 0 & 0 & 0 & 0 & 0 & 16.2 \\
\hline & \multirow{2}{*}{ Bivalves } & Austrovenus stutchburyi & 720.2 & 33367.9 & 54.2 & 78.0 & 517.4 & 152.2 \\
\hline & & Nucula hartivigiana & 954.9 & 1399.3 & 95.2 & 209.5 & 49.6 & 86.1 \\
\hline & Chiton & Sypharochiton pelliserpentis & 0 & 0 & 0 & 0 & 0 & 15.8 \\
\hline \multirow{5}{*}{ Arthropoda } & \multirow{3}{*}{ Crabs } & Halicarcinus whitei & 343.9 & 785.3 & 157.5 & 278.3 & 188.5 & 82.3 \\
\hline & & Hemigraspus crenulatus & 58.2 & 0 & 0 & 0 & 0 & 0 \\
\hline & & Cyclograpsus lavauxi & 11.6 & 27.2 & 4.4 & 0 & 0 & 0 \\
\hline & Isopods & Total unclassified isopods & 66.2 & 20.5 & 0 & 11.9 & 0 & 0 \\
\hline & Amphipods & Total unclassified amphipods & 0 & 207.1 & 3.7 & 127.7 & 0 & 94.3 \\
\hline \multirow[t]{2}{*}{ Annelida } & \multirow[t]{2}{*}{ Polychaetes } & $\begin{array}{l}\text { Total unclassified } \\
\text { polychaetes }\end{array}$ & 74.0 & 299.5 & 9.9 & 36.9 & 61.4 & 55.5 \\
\hline & & Lumbriculus variegatus & 0 & 11.1 & 0 & 0 & 0 & 0 \\
\hline Unknown & & Unidentified Egg Mass & 0 & 201.2 & 4.1 & 45.8 & 0 & 68.6 \\
\hline
\end{tabular}


Table A3.1: Treatments for the Browns Bay trial, in order from leftmost tank to right-most. Back = the end of the tank facing into the seatable and, towards the laboratory. Front = the end of tank facing out of the seatable, away from the laboratory.

\begin{tabular}{|l|l|l|}
\hline Tank \# & Nutrient Treatment & Gastropod End \\
\hline 9 & High + & Back \\
\hline 7 & High & Back \\
\hline 4 & Control & Front \\
\hline 8 & High + & Front \\
\hline 6 & High & Front \\
\hline 2 & Control & Front \\
\hline 3 & High + & Back \\
\hline 5 & High & Front \\
\hline 1 & Control & Back \\
\hline
\end{tabular}

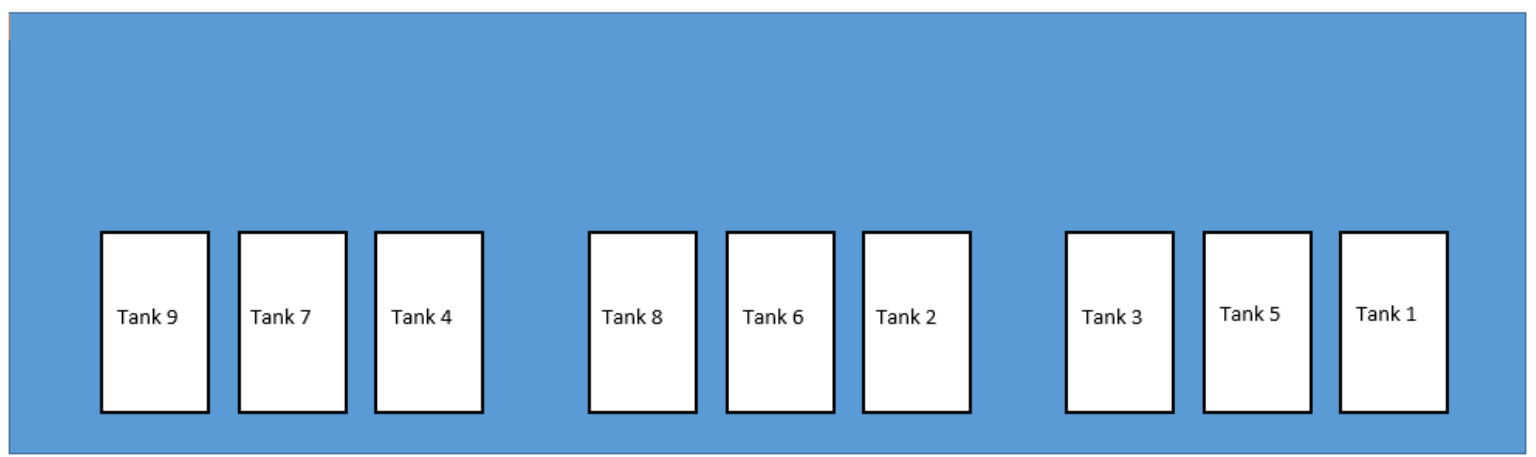

Figure A3.1: Tank positioning for the Browns Bay trial. Tanks are in groups of three (e.g. 9, 7, 4) to avoid shading by vertical beams attached to the seatable structure. Black plastic was used to reduce light reflected from the white surface of the seatable into the tanks. The groups of three were wrapped (e.g. left side of tank 9, around the back of tanks 9, 7 and 4, and right side of tank 4). A shade cloth reduced light from above and front of the tanks. 
Table A3.2: Treatments for the Elsdon trial, in order from left-most tank to right-most. Tank 5 was at 90 degrees to other tanks, due to seatable size. Back $=$ the end of the tank facing into the seatable and, towards the laboratory. Front $=$ the end of tank facing out of the seatable, away from the laboratory.

\begin{tabular}{|l|l|l|}
\hline Tank \# & Nutrient Treatment & Gastropod End \\
\hline 6 & Control & Back \\
\hline 4 & High & Back \\
\hline 2 & Control & Back \\
\hline 9 & High + & Front \\
\hline 1 & High & Front \\
\hline 8 & High + & Back \\
\hline 7 & High & Front \\
\hline 3 & High + & Front \\
\hline 10 & Browns Bay reference tank (Control) & Front \\
\hline 5 & Control & Front \\
\hline
\end{tabular}

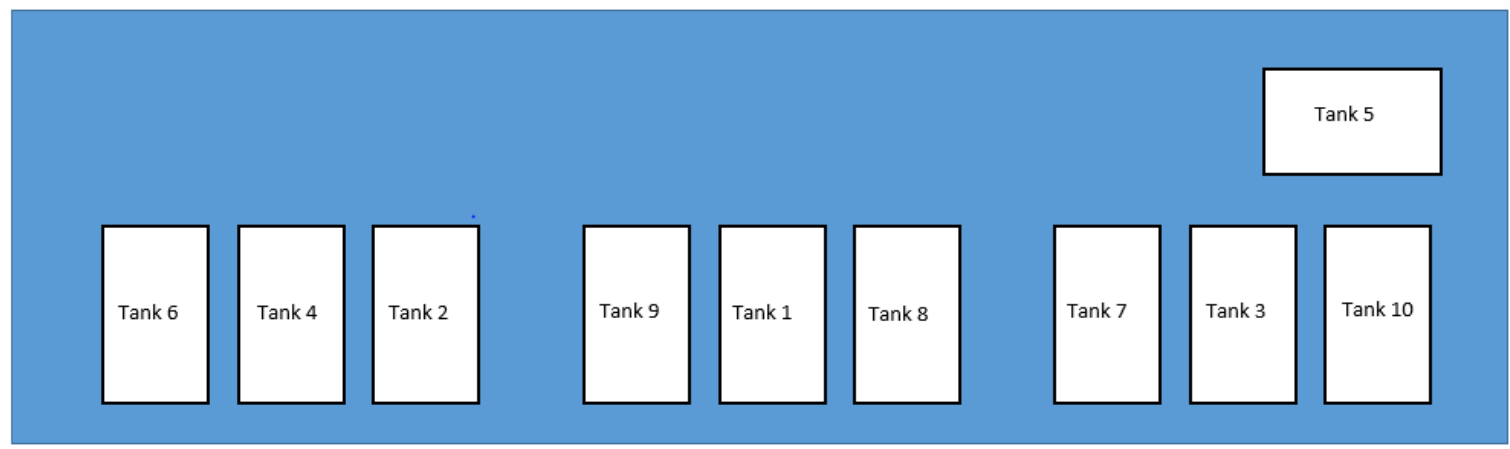

Figure A3.2: Tank positioning for the Elsdon trial. Tanks are in groups of three (e.g. 9, 7, 4) to avoid shading by vertical beams attached to the seatable structure. There was little direct sunlight during this set of experiments, so only the shade cloth was used (draped over the top and front of tanks) to reduce light levels to mimic field conditions. 